SANDIA REPORT

SAND95-2760 • UC-905

Unlimited Release

Printed December 1995

ReC

JAN 154396

$|2-2|$

\title{
Software and Information Life Cycle (SILC) for the Integrated Information Services Organization
}

\section{Adaptations of the Sandia Software Guidelines: Issue B October 16, 1995}

Donna Eaton, Andrea Cassidy, David Cuyler, Shelley Eaton, Scott Joyce, Elisa Kephart, Irene Thurston, Joe Schofield, Dwayne Knirk

Prepared by

Sandia National Laboratories

Albuquerque, New Mexico 87185 and Livermore, California 94550 for the United States Department of Energy under Contract DE-AC04-94AL85000

Approved for public release; distribution is unlimited.
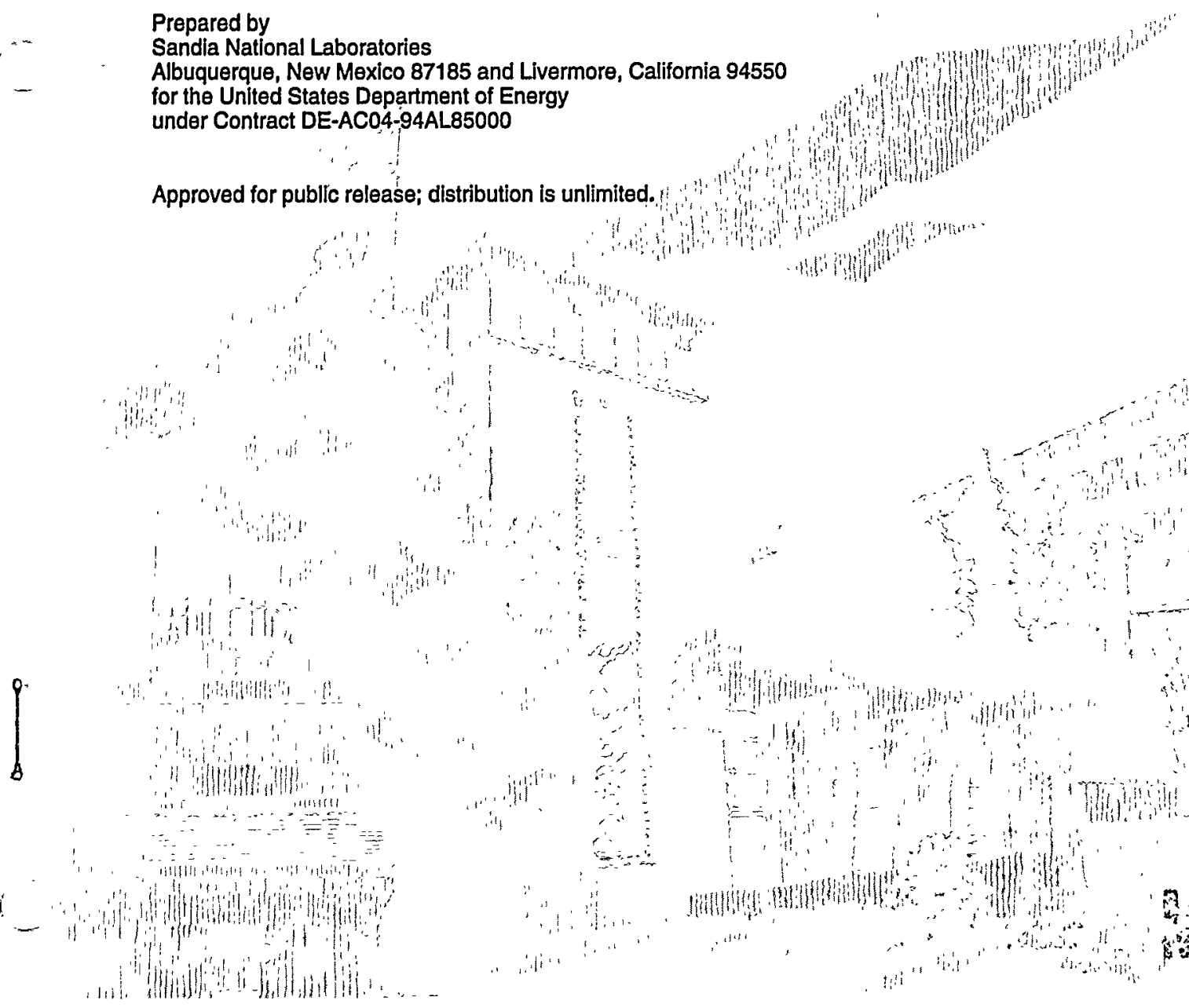
Issued by Sandia National Laboratories, operated for the United States Department of Energy by Sandia Corporation.

NOTICE: This report was prepared as an account of work sponsored by an agency of the United States Government. Neither the United States Government nor any agency thereof, nor any of their employees, nor any of their contractors, subcontractors, or their employees, makes any warranty, express or implied, or assumes any legal liability or responsibility for the accuracy, completeness, or usefulness of any information, apparatus, product, or process disclosed, or represents that its use would not infringe privately owned rights. Reference herein to any specific commercial product, process, or service by trade name, trademark, manufacturer, or otherwise, does not necessarily constitute or imply its endorsement, recommendation, or favoring by the United States Government, any agency thereof or any of their contractors or subcontractors. The views and opinions expressed herein do not necessarily state or reflect those of the United States Government, any agency thereof or any of their contractors.

Printed in the United States of America. This report has been reproduced directly from the best available copy.

Available to DOE and DOE contractors from

Office of Scientific and Technical Information

PO Box 62

Oak Ridge, TN 37831

Prices available from (615) 576-8401, FTS 626-8401

Available to the public from

National Technical Information Service

US Department of Commerce

5285 Port Royal Rd

Springfield, VA 22161

NTIS price codes

Printed copy: A06

Microfiche copy: A01 
SAND95-2760

Distribution

Unlimited Release

Printed December 1995

Category UC-905

\title{
Software and Information Life Cycle (SILC) for the Integrated Information Services Organization
}

\author{
Adaptations of the Sandia Software \\ Guidelines: Issue B \\ October 16, 1995
}

Donna Eaton, Andrea Cassidy, David Cuyler, Shelley Eaton, Scott Joyce, Elisa Kephart, Irene Thurston, and Joe Schofield (Integrated Information Services)

Dwayne Knirk (Quality Engineering Department)

Sandia National Laboratories

Albuquerque, NM 87185

\begin{abstract}
This document describes the processes to be used for creating corporate information systems within the scope of the Integrated Information Services (IIS) Center. Issue B describes all phases of the life cycle, with strong emphasis on the interweaving of the Analysis and Design phases. This Issue B supersedes Issue A, which concentrated on the Analysis and Implementation phases within the context of the entire life cycle. Appendix A includes a full set of examples of the deliverables, excerpted from the Network Database. Subsequent issues will further develop these life cycle processes as we move toward enterprise-level management of information assets, including information meta-models and an integrated corporate information model. The phases described here, when combined with a specifications repository, will provide the basis for future reusable components and improve traceability of information system specifications to enterprise business rules.
\end{abstract}


This document is available for viewing on the Sandia Internal Web, under the URL http://sass902d.itd.sandia.gov/SLC_B.pdf 


\begin{tabular}{|c|c|}
\hline Introduction & 1 \\
\hline Software Phases & 6 \\
\hline References & 20 \\
\hline Acknowledgments & 22 \\
\hline Glossary of Terms & 23 \\
\hline Appendix A & A-1 \\
\hline Problem Statement & A-2 \\
\hline Problem Narrative-Version 1 & A-3 \\
\hline Context Diagram & A-7 \\
\hline High-Level Function Diagram & A-8 \\
\hline Business Rules & A-9 \\
\hline Conceptual Information Model & A-11 \\
\hline Constrained Sentences & A-12 \\
\hline Natural Language Model Diagram & A-16 \\
\hline Logical Information Model-IDEF1X Diagram & A-19 \\
\hline Elementary Processes & A-21 \\
\hline Presentation Sets & A-25 \\
\hline Process/Actor State Transition Matrix & A-26 \\
\hline Storyboard Diagrams & A-33 \\
\hline CRUD Matrix & A-35 \\
\hline Extended Presentation Sets & A-37 \\
\hline DB Schema & A-47 \\
\hline
\end{tabular}


Extended Dependencies and Implementation Constraints A-49

IDEFO Decomposition A-53

\begin{tabular}{lc}
\hline Test Plan, Test Database, and Test Data & A-58 \\
\hline Detail Process Specifications \& Algorithms & A-63 \\
\hline External and Internal Interfaces & A-64 \\
\hline List of Reused Functions & A-69 \\
\hline User Documentation & A-70 \\
\hline Test Results & A-72 \\
\hline Appendix B & B-1 \\
\hline
\end{tabular}




\section{Introduction}

This report is designed to serve three overall purposes:

- Short-term:

- To unify the baseline deliverables produced by the analysis and design processes

- To provide guidance for software developers who need to prepare for formal design reviews

- Long-term: To move corporate software and information life cycle processes toward a unified and consistent methodology, serving diverse software development projects at Sandia

\section{Scope}

\section{Short-Term Scope-Deliverables}

This report defines processes and checklists that will move the Integrated Information Services (IIS) organization toward an enterprise-level specification management process that will clarify and document:

- The rules for business operations

- The corresponding requirements for the automated information systems

This report prescribes a useful set of materials that describe the conceptual design of a system. A complete set of these deliverables will provide a development team with an understanding of the desired information system. This set of information will guide the customer, software developer, review team, and management to comprehend system goals, background, and solutions to business problems.

\section{Long-Term Scope-Methodology}

The life cycle of a software product has been defined in many classical software engineering documents (see "References" on page 20). This report adapts the Sandia Software Guidelines to the IIS organization class of information systems. It is written not to replace those documents, but to position Sandia to take advantage of new technologies and tools. It also supports current three-layer or full three-tiered architecture and future distributed computing environments.

This document, Issue B, supersedes Issue A (Reference 20 on page 20), the initial effort to describe the software process. Issue A concentrated on the analysis phase. The analysis and design phases described here are not necessarily two separate processes. They are strongly coupled and may be completed concurrently. The steps require constant evaluation and iteration until the required result is achieved, i.e., the final evolutionary prototype and/or the critical deliverable set. 
This work is on-going; it will continue to evolve in parallel with the dynamic process of applying new technologies within Integrated Information Services (IIS). We publish our efforts here as Issue B, to describe conceptual design and analysis within the context of the entire software life cycle. In this effort to achieve enterprise-level management of information assets, we will move toward information metamodels, rapid prototyping, and an integrated corporate information model.

\section{Desired Future State}

Automatic generation of application systems, based on precisely defined specifications, is the ultimate goal for future information systems. Full configuration management of all specifications at the enterprise level will support dynamic systems and ensure information timeliness, as well as data reliability.

\section{Principles}

We have incorporated the principles stated in the Information Architecture document (Reference 18 on page 20). In addition, a series of "core beliefs" or "guiding principles" contributed to the interaction of this team. These principles capture how the team attempted to understand and advance the software engineering process within the organization. Their inclusion below may contribute to the understanding of this document.

- We take most seriously this opportunity to improve the software development process (hereafter referred to as process).

- The process is our foundation for productivity, improvement, and measurement.

- The process is defined with adequate rigor to earn the confidence of customers.

- A repeatable, documented process will enable us to reduce variation in the quality of our software products.

- The process includes embedded validation and verification techniques, eventually eliminating the need for management review.

- Management leadership in the strategic planning process establishes priorities and fosters integration.

- Responsibility and accountability for conformance to specification for software rests with the software team.

- Each task and deliverable is assessed by the SILC team for the value added to the process.

\section{Impact}

This document represents a plan for moving the development of integrated information systems from our current reality to a desired future state. The process changes by which we attain our desired future state are only possible if management accounts for full life cycle software costs and takes responsibility and ownership for actively balancing initial delivery schedules with total software quality.

The perceived goals of the IIS organization are to:

- Build systems that serve the needs of the enterprise

- Speed the deployment of new applications or enhancements

- Improve traceability of the design specifications at a sharable enterprise-level 
- Reduce overall costs throughout the life cycle (thus allowing for workforce redeployment or acquisition of additional work)

To further these goals, we provide a process that will shift costs and time from coding and nonproductive rework toward the analysis and design phases of the life cycle, addressed in this report. In addition, start-up costs are evident to define and build or acquire and populate a corporate metadata repository (Reference 18 on page 20 ). Overall, we expect total development costs to decline as requirements are gathered correctly and completely the first time.

The success of applying these processes and methodologies and thus attaining management's goals will be possible only if:

- Management enforces this life cycle process, or

- This life cycle process is enforced by a tool requiring changes be made only to the specifications.

\section{Flexibility}

The methodology and deliverable set presented here are designed as a core set to accomplish future enterprise-sharing and requirements traceability goals. The methodology and deliverables can and should be scaled for use in projects of any size.

A document set selection process is described in Reference 3 on page 20. In general, waiving production of any deliverables requires a management decision. For a software development project, the determination metric is based on weighted scores for size, development cost, customer and life cycle characteristics, platform, team experience, political risk, and special requirements from the customer or from the project environment.

Before the desired future state is reached, real problems will surface with loosely interpreted application of this process. Issue $B$ of this document extends Issue $A$ to include the actual development activities; Issue $C$ will extend Issue $B$ to discuss the tailoring of this process to the area of enhancements to existing systems, including commercial systems.

\section{Deployment}

The software and information life cycle is normally described as a series of phases. Although we would prefer that these phases be simplified, we cannot imagine valid justification for skipping any activity or deliverable they prescribe. Overall, we feel that this methodology does not call for any more work than is already applied in current projects. It simply codifies and documents that work.

A compressed time-scale and improved quality result from a more consistent and defined methodology. The evolutionary prototype shortens development time and allows continuous improvement in understanding for both the customer and the software developer. Quality will improve through continuous iteration and refinement of requirements modeling and customer/subject expert evaluations.

The corporate repository for specifications allows the developer access to all models and future functions available for reuse and sharing at a level that is detailed and precise. Rapid application development should result from applying previously developed functions and framework. 
A diagram of the software process using prototyping comes closest to describing the actual steps for development of new software:

Figure 1 Software Process

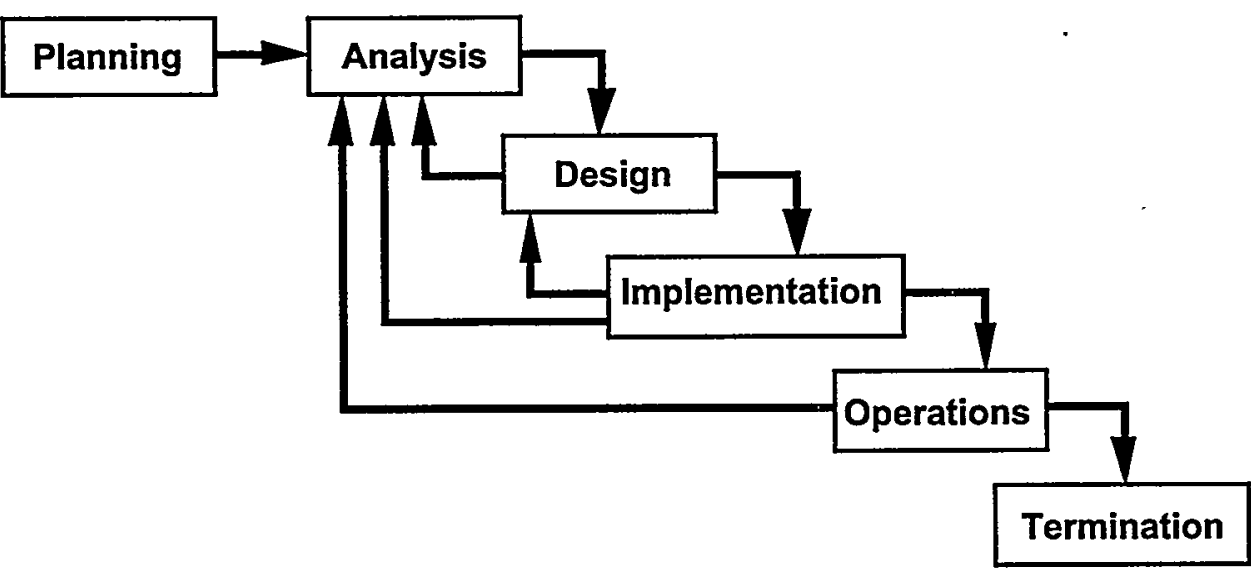

The classic phases are described as steps to apply and deliverables to produce. During the production of these deliverables, evaluation is the key to the completion of that phase or to cycle through the steps again. Both designers and customers need constant feedback, which is the role of evaluation. A formal evaluation may be required to end each phase, depending on the level of risk associated with the software product and its development. The formal design review is recommended currently for all enterprise-wide software implemented by the IIS organization. Management of the IIS organization must choose to waive the formal design reviews.

Even though we discuss phase completion, phases overlap when considered as an iterative development architecture. Figure 2 shows how the phases of a complex software development interweave.

Figure 2 Software Phase Interweaving

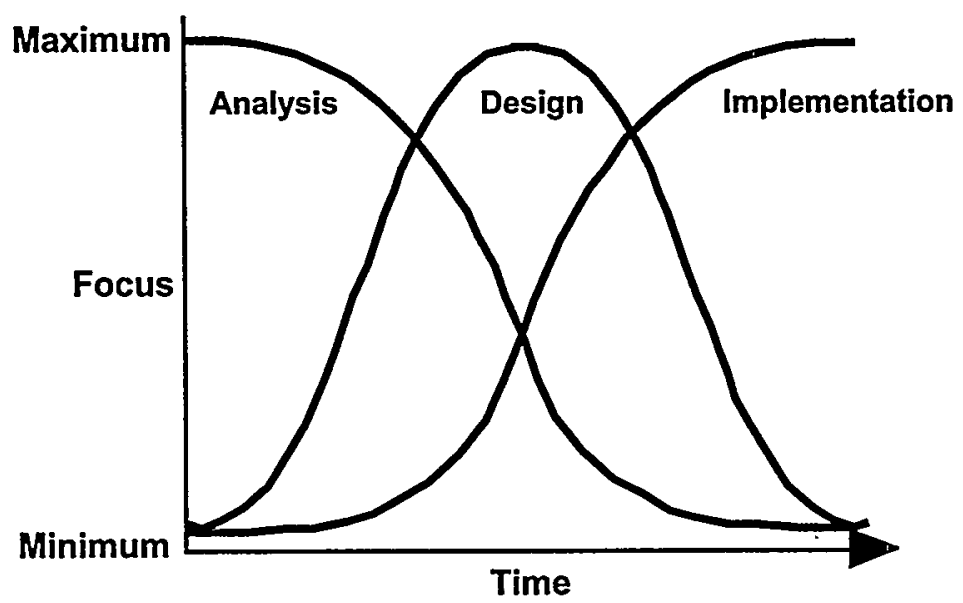

(Adapted from Reference 22 on page 21) 
Interfaces with the corporate repository are equally important as those with the customer, while requirements models are built and refined. The corporate repository is provided by the Data Administration Department as an integration framework for software engineering. This framework consists of the basic infrastructure (i.e., architectural and functional capabilities) to integrate resources, tools, and metadata about software. Figure 3 shows the conceptual architecture of an integration framework.

Figure 3 Conceptual Integration Framework

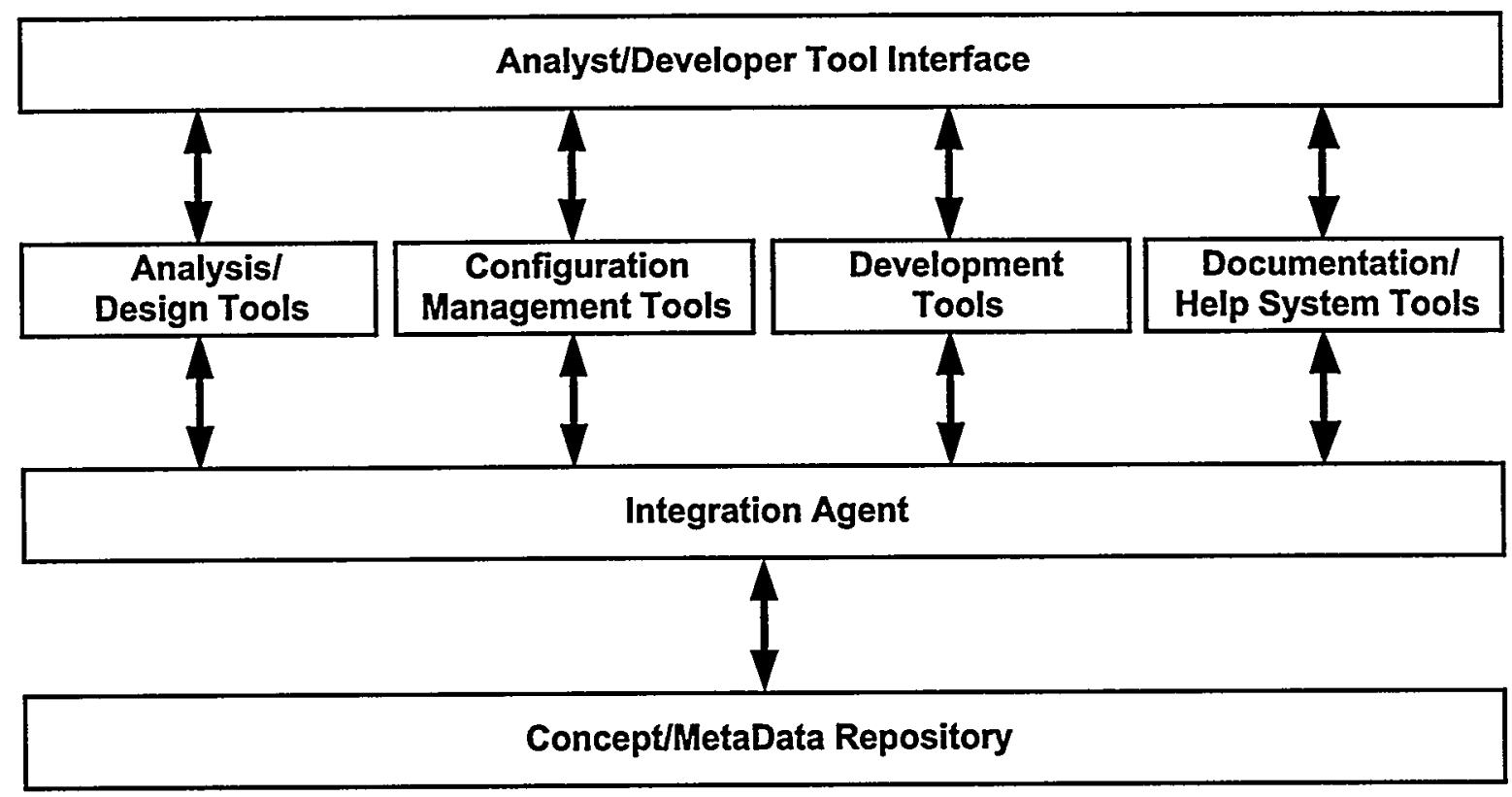

(Adapted from Reference 21 on page 21) 


\section{Software Phases}

\section{Deliverables}

The activities described in the software phases lead to specific software development project deliverables. The following tables indicate the specification deliverable set (Table 1) and extended descriptions of these deliverables (Table 2). In Table 1, numbered items refer to their corresponding definitions in Table 2. The numbered items are covered in more detail in the example shown as Appendix A.

Table 1 Critical Specification Deliverable Set

\begin{tabular}{|c|c|c|c|c|c|}
\hline $\begin{array}{c}\text { Primary } \\
\text { Beneficiary }\end{array}$ & Plan Set & Analysis Set & $\begin{array}{c}\text { Physical Design } \\
\text { Set }\end{array}$ & $\begin{array}{c}\text { Implementation } \\
\text { Set }\end{array}$ & $\begin{array}{c}\text { Operational } \\
\text { Engineering } \\
\text { Set }\end{array}$ \\
\hline Customer & $\begin{array}{l}\text { - Information } \\
\text { systems plan } \\
\text { Project pro- } \\
\text { posal } \\
\text { - Project plan }\end{array}$ & $\begin{array}{l}\text { (1) Problem state- } \\
\text { ment } \\
\text { (2) Business rules } \\
\text { (6) Presentation } \\
\text { sets }\end{array}$ & $\begin{array}{l}\text { (8) Extended pre- } \\
\text { sentation sets } \\
\text { (including flows, } \\
\text { controls, and } \\
\text { screen tem- } \\
\text { plates) }\end{array}$ & $\begin{array}{l}\text { - Data layer pro- } \\
\text { duction data- } \\
\text { base } \\
\text { (16) User docu- } \\
\text { mentation }\end{array}$ & : \\
\hline $\begin{array}{l}\text { Software } \\
\text { engineering } \\
\text { team }\end{array}$ & $\begin{array}{l}\text { - Configuration } \\
\text { management } \\
\text { plan (including } \\
\text { change control) } \\
\text { - Corporate } \\
\text { repository plan } \\
\text { - Records man- } \\
\text { agement plan } \\
\text { - Computer } \\
\text { security plan } \\
\text { - Corporate } \\
\text { Style Guides }\end{array}$ & $\begin{array}{l}\text { (3) Conceptual } \\
\text { information } \\
\text { model } \\
\text { (4) Logical informa- } \\
\text { tion model } \\
\text { (5) Elementary pro- } \\
\text { cesses }\end{array}$ & $\begin{array}{l}\text { (7) CRUD matrix } \\
\text { (9) DB schema } \\
\text { (10)Extended } \\
\text { dependencies \& } \\
\text { implementation } \\
\text { constraints } \\
\text { *(11)IDEFO decom- } \\
\text { position } \\
\text { (12)Test plan, test } \\
\text { database, and } \\
\text { test data } \\
\text { *(13)Detail process } \\
\text { specifications } \\
\text { and algorithms } \\
\text { (may include } \\
\text { design deci- } \\
\text { sions) } \\
\text { (14)External and } \\
\text { internal inter- } \\
\text { faces (may } \\
\text { include conver- } \\
\text { sion map) } \\
\text { (15)List of reused } \\
\text { functions }\end{array}$ & $\begin{array}{l}\text { - Implementation } \\
\text { checklist com- } \\
\text { pleted } \\
\text { - Presentation } \\
\text { layer application } \\
\text { - Functional layer } \\
\text { components }\end{array}$ & \\
\hline $\begin{array}{l}\text { Operations } \\
\text { team }\end{array}$ & $\begin{array}{l}\text { - System-level } \\
\text { requirements }\end{array}$ & & & & $\begin{array}{l}\text { - Operational } \\
\text { specification }\end{array}$ \\
\hline Review team & $\begin{array}{l}\text { - Metric plan } \\
\text { - Quality assur- } \\
\text { ance plan }\end{array}$ & $\begin{array}{l}\text { CDR } \\
\text { "Conceptual } \\
\text { Design Review" or } \\
\text { "Preliminary } \\
\text { Design Review" }\end{array}$ & $\begin{array}{l}\text { DDR } \\
\text { "Detailed Design } \\
\text { Review" or } \\
\text { "Critical Design } \\
\text { Review" }\end{array}$ & $\begin{array}{l}\text { (17)Test results } \\
\text { FDR } \\
\text { "Final Design } \\
\text { Review" or } \\
\text { "Pre-Produc- } \\
\text { tion Review" }\end{array}$ & \\
\hline
\end{tabular}

* indicates optional items. 
Table 2 Descriptions of Deliverables Produced by the Processes in Table 1

\begin{tabular}{|c|c|c|c|c|}
\hline & Deliverable & $\begin{array}{l}\text { Primary } \\
\text { Communication } \\
\text { Roles }\end{array}$ & $\begin{array}{l}\text { Depen- } \\
\text { dencies }\end{array}$ & Description \\
\hline 1 & Problem statement & Customer : Analyst & (none) & $\begin{array}{l}\text { Consists of: } \\
\text { Problem narrative-a textual deliver- } \\
\text { able that states the business prob- } \\
\text { lem in concise terms } \\
\text { Context diagram-may be included } \\
\text { to show the scope of the system and } \\
\text { which objects flow between the sys- } \\
\text { tem and an external system inter- } \\
\text { face. Large problems should be } \\
\text { decomposed into subsystems that } \\
\text { can be defined in two to three pages. }\end{array}$ \\
\hline 2 & Business rules & Customer : Analyst & (1) & $\begin{array}{l}\text { Formal natural language sentences with } \\
\text { examples specify aspects of each object } \\
\text { to be maintained in the information } \\
\text { system. Initial storyboards or cartoons } \\
\text { and flow diagrams are also used to } \\
\text { document the business rules and verify } \\
\text { them with the customer. General } \\
\text { constraints and derivation rules are } \\
\text { included in textual form. }\end{array}$ \\
\hline 3 & $\begin{array}{l}\text { Conceptual information } \\
\text { model }\end{array}$ & Analyst : Designer & (2) & $\begin{array}{l}\text { Constrained sentences in textual form } \\
\text { and in a natural language model diagram } \\
\text { communicate precisely the information } \\
\text { required by the designer. }\end{array}$ \\
\hline 4 & Logical information model & Analyst : Designer & (3) & $\begin{array}{l}\text { The database structure (without vendor } \\
\text { software or implementation } \\
\text { considerations) is documented with a } \\
\text { diagram of the form used in IDEF1X (a } \\
\text { FIPS representation of an ER model). }\end{array}$ \\
\hline 5 & Elementary processes & Analyst : Designer & $(4,2)$ & $\begin{array}{l}\text { Elementary processes that represent } \\
\text { the smallest units of work which can be } \\
\text { executed to modify the content of the } \\
\text { information base, and which will leave } \\
\text { the information base in a state consistent } \\
\text { with integrity rules. }\end{array}$ \\
\hline
\end{tabular}


Table 2 Descriptions of Deliverables Produced by the Processes in Table 1 (Continued)

\begin{tabular}{|c|c|c|c|c|}
\hline & Deliverable & $\begin{array}{c}\text { Primary } \\
\text { Communication } \\
\text { Roles }\end{array}$ & $\begin{array}{l}\text { Depen- } \\
\text { dencies }\end{array}$ & Description \\
\hline 6 & Presentation sets & $\begin{array}{l}\text { Customer : Analyst } \\
\text { Analyst : Designer }\end{array}$ & $(5,2)$ & $\begin{array}{l}\text { Consists of: } \\
\text { Process/Actor State Transition } \\
\text { Matrix-adds rigorous definitions of } \\
\text { the processes related to each object. } \\
\text { In addition, from the customer's } \\
\text { viewpoint, it helps integrate the } \\
\text { actions performed and the state of } \\
\text { the information system for each ele- } \\
\text { mentary process. } \\
\text { Completed storyboard diagrams with } \\
\text { annotated sets denoting groups of } \\
\text { data items to be treated as a single } \\
\text { unit (as in elementary processes). } \\
\text { Standard templates, when available, } \\
\text { will be applied to provide a consis- } \\
\text { tent "look and feel" with other sys- } \\
\text { tems. } \\
\text { Event and process lists define the } \\
\text { system behaviors as related to the } \\
\text { storyboards. }\end{array}$ \\
\hline 7 & CRUD matrix & $\begin{array}{l}\text { Designer : } \\
\text { Implementer }\end{array}$ & $(4,5,6)$ & $\begin{array}{l}\text { The CRUD (Create, Read, Update, } \\
\text { Delete) matrix identifies each elementary } \\
\text { process used on each core object of the } \\
\text { information system. This assists in } \\
\text { verifying that each object is supported by } \\
\text { a create, read, update, and delete } \\
\text { process-it also helps identify } \\
\text { redundancy of processes for an object. }\end{array}$ \\
\hline 8 & $\begin{array}{l}\text { Extended presentation } \\
\text { sets }\end{array}$ & $\begin{array}{l}\text { Customer: Designer } \\
\text { Designer: } \\
\text { Implementer }\end{array}$ & (6) & $\begin{array}{l}\text { Storyboard diagrams that include } \\
\text { vendor-specific and implementation- } \\
\text { specific features, as well as application } \\
\text { of standard template features for the } \\
\text { enterprise systems. }\end{array}$ \\
\hline 9 & DB schema & $\begin{array}{l}\text { Designer: } \\
\text { Implementer }\end{array}$ & (4) & $\begin{array}{l}\text { The Physical Database, using the } \\
\text { constructs of the vendor software and } \\
\text { the additional information needed by the } \\
\text { implementer of the system, is } \\
\text { documented with the database schema } \\
\text { diagram in the form of IDEFIX. } \\
\text { Optionally, the SQL listings may be used. }\end{array}$ \\
\hline & $\begin{array}{l}\text { Extended dependencies } \\
\text { and implementation } \\
\text { constraints }\end{array}$ & $\begin{array}{l}\text { Designer : } \\
\text { Implementer }\end{array}$ & $(6,2)$ & $\begin{array}{l}\text { A formal definition of precedence } \\
\text { required in the behavior steps. }\end{array}$ \\
\hline
\end{tabular}


Table 2 Descriptions of Deliverables Produced by the Processes in Table 1 (Continued)

\begin{tabular}{|c|c|c|c|}
\hline Deliverable & $\begin{array}{c}\text { Primary } \\
\text { Communication } \\
\text { Roles }\end{array}$ & $\begin{array}{l}\text { Depen- } \\
\text { dencies }\end{array}$ & Description \\
\hline 11 IDEF0 decomposition & $\begin{array}{l}\text { Customer : Analyst } \\
\text { Analyst : Designer }\end{array}$ & $(2,5,7)$ & $\begin{array}{l}\text { IDEF0 decomposition is a formal, } \\
\text { hierarchical breakdown of the functions } \\
\text { or processes that the software will } \\
\text { provide. In addition to showing these } \\
\text { processes in progressively more detail, } \\
\text { these graphical charts also emphasize } \\
\text { the inputs, which are transferred by the } \\
\text { processes, and the outputs that result } \\
\text { from the processes. They also show } \\
\text { inputs that are not transformed, but are } \\
\text { controls on the processes, and the } \\
\text { "mechanisms" that are involved or used } \\
\text { by the processes. }\end{array}$ \\
\hline $\begin{array}{l}12 \text { Test plan, test database, } \\
\text { and test data }\end{array}$ & $\begin{array}{l}\text { Designer: } \\
\text { Implementer }\end{array}$ & $(2,9,10)$ & $\begin{array}{l}\text { Test data may be acquired in the } \\
\text { modeling phase as valid and invalid } \\
\text { examples of each fact. The design of the } \\
\text { test plan will validate the modeling } \\
\text { examples, in addition to other tests as } \\
\text { needed to check the algorithms and the } \\
\text { output or results of the processes and } \\
\text { the system. The test database will be a } \\
\text { significant data set to establish and carry } \\
\text { out the test plan. It must be a reusable } \\
\text { baseline database, and it should be } \\
\text { established early in the prototyping } \\
\text { process. }\end{array}$ \\
\hline $\begin{array}{l}13 \text { Detail process } \\
\text { specifications and } \\
\text { algorithms (may include } \\
\text { design decisions) }\end{array}$ & $\begin{array}{l}\text { Designer: } \\
\text { Implementer }\end{array}$ & $(8,10)$ & $\begin{array}{l}\text { Processes, other than elementary } \\
\text { processes and functions that can be } \\
\text { generated from the models, should be } \\
\text { documented to the level of detail that } \\
\text { would eventually assist in the generation } \\
\text { of code. Several formats will suffice, until } \\
\text { an automatic code generation tool is } \\
\text { chosen or written. (See Appendix A for } \\
\text { formats.) }\end{array}$ \\
\hline $\begin{array}{l}14 \text { External and internal } \\
\text { interfaces (may include } \\
\text { conversion map) }\end{array}$ & $\begin{array}{l}\text { Designer: } \\
\text { Implementer }\end{array}$ & $(5,9)$ & $\begin{array}{l}\text { Most systems rely on data and controls } \\
\text { from other systems, either by direct } \\
\text { network links or file transfer. The } \\
\text { interfaces must be documented to the } \\
\text { level of detail required for future } \\
\text { maintenance of the software. } \\
\text { If the data must be converted for this } \\
\text { application, a conversion map will show } \\
\text { the input and transformation of each } \\
\text { field, and the mapping to the new } \\
\text { software. }\end{array}$ \\
\hline 15 List of reused functions & $\begin{array}{l}\text { Designer: } \\
\text { Implementer }\end{array}$ & $(10,13)$ & $\begin{array}{l}\text { Sharable routines such as functions and } \\
\text { methods will be documented. Those } \\
\text { existing functions found in the repository } \\
\text { will be listed, along with new sharable } \\
\text { routines that are additions to the } \\
\text { repository. }\end{array}$ \\
\hline
\end{tabular}


Table 2 Descriptions of Deliverables Produced by the Processes in Table 1 (Continued)

\begin{tabular}{|c|c|c|c|}
\hline Deliverable & $\begin{array}{c}\text { Primary } \\
\text { Communication } \\
\text { Roles }\end{array}$ & $\begin{array}{l}\text { Depen- } \\
\text { dencies }\end{array}$ & Description \\
\hline 16 User documentation & $\begin{array}{l}\text { Implementer: } \\
\text { Customer }\end{array}$ & $\begin{array}{l}(3,6,8 \\
10,17)\end{array}$ & $\begin{array}{l}\text { At a minimum, the documentation set } \\
\text { includes online help and a printed quick } \\
\text { reference card. A writer will manage } \\
\text { production of the materials, working with } \\
\text { the application developer and the } \\
\text { customer. }\end{array}$ \\
\hline 17 Test results & $\begin{array}{l}\text { Implementer: } \\
\text { Designer } \\
\text { Designer : Customer }\end{array}$ & (12) & $\begin{array}{l}\text { Following the test plan, a tester } \\
\text { documents results in a standard } \\
\text { template. This would include the results } \\
\text { from testing complex functions and } \\
\text { algorithms. }\end{array}$ \\
\hline
\end{tabular}

\section{Planning Phase}

\section{Enterprise-Wide Business Planning}

Enterprise-wide business planning and information modeling are the preferred front-end to all information system development.

Sometimes called Information Strategic Planning (ISP), this process identifies the state of and the needs for data, process, and organizational alignment. Strategic information planning for business systems within the corporate information model includes prioritizing, sequencing, and scoping of business areas. This planning provides the foundation for future decisions regarding the selection of business areas for development, redevelopment, and business process re-engineering. A stronger emphasis on strategic and integrated planning is advocated as the number of systems, platforms, and technologies increase.

\section{Planning Phase Steps-Corporate Level}

Members of top-level management participate in corporate information systems planning to develop critical success factors for the business:

1. The corporate-level planners create association matrices that correlate organizations, data, and processes.

2. The participants identify and resolve matrix inconsistencies.

3. The participants produce a prioritized list of information development efforts. As process owners they often propose a set of solutions, from which one is chosen to be studied and developed into a system proposal by software engineers.

4. The participants produce an organizational structure established on information flows and usage.

\section{Planning Phase Steps-Project Level}

This life cycle phase involves the conceptual development of a computer solution to a business need. The planning phase may be very short if the project is described in an overall business strategic plan. However, often the project is dynamically created as an evolution of business changes in reaction to changing circumstances. Many projects result 
from a formal change control system, where changes and enhancements require extensive work.

1. The information system analysts develop a project proposal. They begin to scope the problem, assess the current systems, and describe a set of steps with estimates of costs and schedules for each. Once approved, the recommended solution is documented in procedures and policy documents as the business rules for the enterprise. The IIS is requested to build or acquire a system to support these rules.

2. The information system analysts write a project plan. A complete plan includes the goals, objectives, deliverables, milestones, estimates of resources, and schedules. They consider the following mechanisms:

- Configuration Management Architecture (includes change control)

- Quality Assurance Architecture

- Records Management Architecture

- Corporate Repository Architecture (includes reuse procedures)

3. The software engineers analyze and document system-level requirements and constraints, including:

- Overview of product perspective and functions overview

- Description of future state

- Intended users and usage scenarios

- System general constraints-limits on design decisions

- External interfaces-hardware and software plans, communications plans

- References to standards and guidelines that apply

- Security constraints/data sensitivity/protections - an analysis to determine the highest level of data protection needed for the system, and the expected granularity of protections required for the data

- References for risk management plan

4. The software engineers develop a quality assurance plan, which includes:

- References for standards, tools, technologies, and integration with Software Management Plan requirements (SLP 1011)

- Metrics plan

- References for configuration management plan (specifications, documents, code, media, supplies, data)

- References for design decision documents and audit/review results

- References for records management plan (collection, maintenance, retention, archiving, deletion)

\section{Analysis Phase}

Analysts perform this phase by working directly with the customer, precisely defining the information facts managed by this information system (application). The preferred methodology for standard specifications is one of those presented in the Sandia Software Guidelines (Reference 6 on page 20). This methodology has been further developed to support modeling processes and events, in addition to information modeling. Because the 
natural language of both customer and analyst is used, communication is greatly enhanced.

The quality of a rigorous analysis phase produces the desired specifications to be managed at the enterprise level. Analysts will use a version-controlled repository to manage all model constructs. This enterprise-level tool helps manage reusable information and functions for multiple models and systems. The repository will eventually support automatic generation of information systems and business rule descriptions.

\section{Analysis Phase Steps}

1. The analysts define a scope or "universe of discourse" to set boundaries on the problem. In addition, they develop a problem statement, including a problem narrative, context diagrams, and other descriptive materials.

2. The analysts query the repository for existing building blocks to support the software engineering reuse of model constructs. As new objects are created in the natural language models, they must be coordinated with the data administrator. The data administrator will add these objects to the repository if they are not already defined and used in other systems. Negotiations with the data administrator will be necessary for classifying new objects and functions, i.e., to leave them as local definitions (for this application) or to promote them to enterprise-shareable status.

3. The analysts create a natural language (English sentences) model from the building blocks selected from the enterprise model repository and from newly defined constructs resulting from analyst-customer reviews. This model rigorously defines the information, its meanings, identifiers, relationships, and constraints (especially mandatory and uniqueness requirements).

4. The analysts produce a natural language process model and graphical presentation model to define precisely the processes that will act on the information. (The model can include storyboards, known as presentation sets or prototypes.) Constraints and derivation rules are expressed textually and through concrete examples. Each analystcustomer review of the specifications should produce further refinements to the model as more areas of interest are discovered, and all business rules are brought out and explicitly documented, using a set of customer-provided examples.

5. The analysts repeats Steps 3 and 4 until the model completely specifies the problem scope and until the customer and process owner agree on its completeness. The customer or process owner and analysts accept this reviewed analysis set by formal sign-off.

6. The analysts schedule a conceptual review (see "Glossary of Terms" on page 23) to verify the specifications produced in this analysis of this application or subsystem. The review may also be attended by business experts and technology experts, including the developers. Other aspects of the system may be addressed in this review, such as training and special requirements.

\section{Analysis Phase-Future Goals}

An ongoing goal in the evolution of this methodology is to shift the traditional notion of testing earlier in the life cycle through the verification and validation of specifications. The examples collected during the analysis play a critical role in the validation process. At some future point, confidence in the rigor of the specification and development process 
should reduce our reliance on classical unit, integration, system, and acceptance testing. Reasons for shifting this emphasis include:

- The growing sophistication and reliability of software analysis and design tools will assure that generated code performs in accordance to the specification from which the code was generated. We will only need to test that the code generated from a specification of ideal behavior actually does what is intended in the real computing system, interacting with hardware, the operating system components, and other applications.

- The traditional "acceptance test plan" can be derived with tool assistance and the validation completed from the English syntax used to capture requirements and examples.

- Presentation sets developed from prototyping tools serve as training and communication vehicles, establishing a foundation for eventual customer acceptance.

- By managing the design intent, traceability to business practices can be maintained for expected gains in business process improvement and business re-engineering.

\section{Physical Design Phase}

This step will use the specifications and extend them into a physical database schema and either an extended specification or an evolutionary prototype. The system designers should be knowledgeable developers with experience in building and using preferred technology information systems tools, as bounded by the standard architecture of the IIS systems. The designers should also have skills in human factors engineering as well as the classical programming training and skills.

The designers will specify the amount of flexibility of design format regarding the presentation sets transmitted to the development team. Aiming for consistency and usercentered design, human factors guidelines will affect the screen design and planned system behaviors.

The designers will also consider implementation perspectives. Future presentation, functional, and data layer guidelines, along with assistance from the data administrator, will direct the choice of the components of the three-tier model. Choice of certain vendors' tools may impose physical constraints on the implementation. The design will address those issues that were not specified in the analysis phase.

The risks associated with the software product and its development affect the choice of which of the following optional documentation elements the team will produce and review:

- Decomposition. IDEF0 is the demonstrated format in this example, as it is the Government standard for documenting process decomposition.

- Detail Description and Algorithms. Data derivations, known as derived facts

\section{Physical Design Steps-Presentation Layer}

1. The designers extend the presentation sets and screens, considering Human Computer Interaction (HCI) and following standard templates and $\mathrm{HCI}$ guidelines. In either hard copy form or software, this deliverable evolves into a prototype. Based on the information model that contains the information requirements, a prototype can 
resemble the final product for data input as described by the elementary processes from the analysis phase. The designers produce the prototype using templates, reusable processes, and the latest technology tools.

2. The designers document flows and controls (which may also be in the functional layer) and include a list of edits. These edits control the occurrence of triggering events. As presentation elements, they indicate points of user input. Here the designers also include guidelines for choosing pick lists and checklists over user input, based on known factors such as data changeability and volume.

\section{Physical Design Steps-Functional Layer}

1. The designers and data administrator identify all reusable facts and functions.

2. The designers describe the physical design. External and internal critical interfaces include:

- (External) control data from other sources, working data, and time-dependent triggers

- (Internal) data and message passing in the system

\section{Physical Design Steps-Data Layer}

1. The designers plan for the production of the physical schema by proposing extensions to the logical schema. Here the designers:

- Add the surrogate (generated) keys

- Denormalize selected tables to enhance performance and ease of use

- Apply estimates and statistics, which indicate where additional alternate keys should be placed and indexes used

- Add protection and controls by examining data sensitivity and adding row level protections where necessary

- Design access paths, which may include more indexes, key placement in tables, etc.

- Add and document additional requirements to the schema, for such functions as tracing or archiving-these should be developed from functional processes rather than information requirements at this phase

2. The designers develop test data from examples the analysts stored in the repository and they map the examples to database tables. Future plans call for the development of a utility to automate this function.

3. The designers and customer formulate a conversion map for external interfaces. The map will be used to populate the database with existing legacy data or any continuing external controls and output formats to interface with other systems.

\section{Physical Design Steps-Completion}

1. The designers document and cross-reference all design decisions and the processes affected by them.

2. The designers add the physical model and general constraints (other rules and information, not contained in the model) to the repository.

3. The designers hold a Detailed Design Review to verify the physical design. 


\section{Implementation Phase}

The implementation of a system requires skilled developers and the coordination of many interfaces to produce a new system and to put it into production. In the future, as system code is automatically generated, the coordination of interfacing workgroups will take on even more importance to:

- Complete the system

- Test the system

- Set up such components as networks, security plans, training, and production procedures

\section{Implementation Phase Steps}

1. The database administrator creates the physical database, distributed location and features, and access requirements.

2. The database administrator provides a test database to the customer and the implementers. Test data is created using the test data map provided by the designers.

3. The implementers build the presentation layer components according to the current software and hardware architecture and standards of the IIS systems. Where possible, the functional layer programs will be generated directly from the specifications.

4. The implementers build the functional layer components not already available in the corporate repository, according to the current software/hardware architecture and standards of the IIS systems. Where possible, the code will be generated directly from the specifications.

5. The implementers perform integrated testing against the test database.

6. The implementers perform system testing on the corporate test bed system.

7. The implementers hold an as-built design review for the pre-production application.

8. The implementers perform the steps of the deployment process to move the system into a fully operational production system.

\section{Implementation Steps-Deployment}

This process or sub-phase includes verification, training, and production definition to move the system into a production phase where the application will be available as a corporate asset. The deployment coordinator should possess the skills necessary to manage enormous amounts of data and place the required modules and components in a configuration management system. The deployment manager must also be able to perform multiple tasks and manage coordination of schedules of many customer and IIS groups.

1. The analysts and production specialist define the processing duplication, i.e., parallel runs for validation and verification requirements.

2. The analysts and customer populate the production database with the static data and legacy data.

3. The network administrator and production specialist connect the networks to access related and dependent data from other systems. 
4. The analysts, customer, and training services develop the training classes and train users, as well as production support staff and help desk personnel. This team also develops user documentation.,

5. The production specialist and analysts develop operational procedures, including company asset protection processes and plans.

6. The analysts and production specialist perform a customer acceptance review of the Final Design Review, with an official sign-off for the system.

\section{Information Systems Implementation Checklist}

Table 3 on page 17 indicates the checklist as currently defined. The checklist is also available on the World Wide Web:

http://www_irn.sandia.gov/organization/div13000/isiproc/isistart.htm)

The checklist is a standard that incorporates required sign-offs necessary for moving new systems into production and enhancing existing ones within the Integrated Information Services Organization. This process ensures continued support without dependence on the original developer. It is used by developers and the production representative to identify stakeholders who need to be contacted as products are developed. The upper portion of the checklist (above the double line) contains early life cycle considerations. Items in the lower portion of the checklist (below the double line) are coordinated before the product is released.

The Production Center Implementation Coordinator is the single point-of-contact for questions about this process. In addition, this Coordinator will serve as or provide a production representative as a full member of the project team. This representative will:

- Coordinate with all production support stakeholders who are not project team members

- Ensure that production requirements are included in the project plan with reasonable milestone schedules and ensure that these milestones are met (including responsibility for writing some of the required documents)

- Write the service-level agreements documenting operational and performance requirements 
Table 3 Information Systems Implementation Checklist

\begin{tabular}{|c|c|c|c|c|c|}
\hline $\begin{array}{l}\text { Consult with } \\
\text { End Customer } \\
\text { about ... }\end{array}$ & $\begin{array}{l}\text { Consult with } \\
\text { System } \\
\text { Administration } \\
\text { about... }\end{array}$ & $\begin{array}{l}\text { Consult with } \\
\text { Application } \\
\text { Support } \\
\text { about... }\end{array}$ & $\begin{array}{l}\text { Consult with } \\
\text { Technical Test } \\
\text { Bed about... }\end{array}$ & $\begin{array}{c}\text { Consult with } \\
\text { Data and } \\
\text { Database } \\
\text { Administration } \\
\text { about... }\end{array}$ & $\begin{array}{l}\text { Consult with } \\
\text { Network } \\
\text { Communica- } \\
\text { tions, Security, } \\
\text { and } \\
\text { Production } \\
\text { Services } \\
\text { about... }\end{array}$ \\
\hline $\begin{array}{l}\square \text { application } \\
\text { requirements } \\
\square \text { performance } \\
\text { requirements } \\
\square \text { access control }\end{array}$ & $\begin{array}{l}\square \text { server software } \\
\text { requirements } \\
\square \text { server hard- } \\
\text { ware require- } \\
\text { ments }\end{array}$ & $\square$ transition plan & $\begin{array}{l}\text { workstation and } \\
\text { PC installation } \\
\text { and execution } \\
\text { requirements } \\
\square \text { architectural } \\
\text { compliance } \\
\text { including where } \\
\text { applications } \\
\text { reside and exe- } \\
\text { cute } \\
\square \text { system design } \\
\text { reviews }\end{array}$ & $\begin{array}{l}\text { Data Adminis- } \\
\text { tration data mod- } \\
\text { eling require- } \\
\text { ments } \\
\text { Data require- } \\
\text { ments including } \\
\text { backup and } \\
\text { recovery, secu- } \\
\text { rity, conversion, } \\
\text { volumes and } \\
\text { growth, source/ } \\
\text { target and } \\
\text { archive/delete }\end{array}$ & $\begin{array}{l}\text { Q Production Ser- } \\
\text { vices documen- } \\
\text { tation require- } \\
\text { ments } \\
\text { a Security data } \\
\text { security classifi- } \\
\text { cations and } \\
\text { security plans } \\
\text { a Network Com- } \\
\text { munications traf- } \\
\text { fic tolerances } \\
\text { and network } \\
\text { needs }\end{array}$ \\
\hline $\begin{array}{r}\text { 口 early life cycle } \\
\text { aspects above }\end{array}$ & $\begin{array}{r}0 \text { early life cycle } \\
\text { aspects above }\end{array}$ & $\begin{array}{c}\square \text { early life cycle } \\
\text { aspect above }\end{array}$ & $\begin{array}{l}\square \text { early life cycle } \\
\text { aspects above }\end{array}$ & $\begin{array}{r}\square \text { early life cycle } \\
\text { aspects above }\end{array}$ & $\begin{array}{l}\text { early life cycle } \\
\text { aspects above }\end{array}$ \\
\hline $\begin{array}{l}\text { customer accep- } \\
\text { tance and verifi- } \\
\text { cation testing }\end{array}$ & $\begin{array}{l}\text { 口 backup and } \\
\text { recovery require- } \\
\text { ments } \\
\square \text { scheduling and } \\
\text { compatibility of } \\
\text { system software } \\
\text { installs and } \\
\text { upgrades (soft- } \\
\text { ware integration) } \\
\square \text { stress test }\end{array}$ & $\begin{array}{l}\square \text { change control } \\
\text { procedures } \\
\square \text { negotiated level } \\
\text { of support } \\
\square \text { hardware and } \\
\text { software training } \\
\text { for supporting } \\
\text { staff }\end{array}$ & $\begin{array}{l}\text { product exe- } \\
\text { cutes on stan- } \\
\text { dard platforms } \\
\square \text { software distri- } \\
\text { bution needs }\end{array}$ & $\begin{array}{l}\square \text { conformance to } \\
\text { database stan- } \\
\text { dards } \\
\square \text { database perfor- } \\
\text { mance consider- } \\
\text { ations } \\
\square \text { database imple- } \\
\text { mentation }\end{array}$ & $\begin{array}{l}\square \text { Production Ser- } \\
\text { vices service } \\
\text { level agree- } \\
\text { ments } \\
\square \text { Production Ser- } \\
\text { vices Help Desk } \\
\text { needs } \\
\square \text { Production Ser- } \\
\text { vices final sign- } \\
\text { off of completed } \\
\text { checklist }\end{array}$ \\
\hline
\end{tabular}

\section{Operation Phase}

The operation phase, traditionally called the production phase and maintenance phase, will be viewed as static, operational processes until the business rules change. This phase requires quality management techniques to assure the integrity and protection of valuable corporate assets and to maintain customer delight during day-to-day business operations. This phase requires extensive configuration management tools and an intensive commitment to the maintenance of the specifications and constructs in the corporate repository.

An application in the operation phase requires the entire software life cycle process to implement new requirements. To the extent required, all procedures will be performed as outlined in the life cycle phases: Planning, Analysis, Physical Design, and Implementation. 


\section{Operation Phase Steps}

1. The analysts and designers determine changes to the system specifications.

2. The implementers generate changes in operational software from changes to the new system specifications. Initially coding will progress with current tools, eventually progressing to automatic generation of the software application code.

3. The analysts and designers are responsible for the documentation of new business rules resulting from the system changes. Initially these documents will be manuallygenerated, with text generation development eventually progressing to the point of automatic generation of the information system specifications and automatic generation of the business-rule documents.

\section{Termination Phase}

The system will be closed out after it is no longer needed.

\section{Termination Phase Steps}

1. The production specialist moves any legacy data with continuing requirements to other systems.

2. Corporate Records Management evaluates the transfer of specifications and historical information to be retained for proper disposition and thereafter saved and managed by that organization.

3. The data administrator removes from the corporate repository constructs and process specifications that are no longer required for this or other systems.

\section{Summary}

The software process we have described will be used, evaluated, and modified in a continuing process improvement cycle. As technology changes and tools and architecture become more stable, this life cycle process will be modified to incorporate current best practices.

“...Good systems are not developed by only using the correct methods. A system is developed by people who are motivated, willing, and able to use the appropriate technology," wrote Fleischmann (Reference 23 on page 21). To manage the project, a strong leader is vital, as well as different team structures based on the right team mix of technical and social skills and the variation in work packages for each unique software project. "Program development is done by people; there they are the most important resource," noted DeMarco (Reference 24 on page 21). With the addition of the balanced mix of team members and methods and processes, plus supportive management and toolsets, the software and information life cycle may be summarized graphically as in Figure 4. 
Figure 4 Roles and Responsibilities

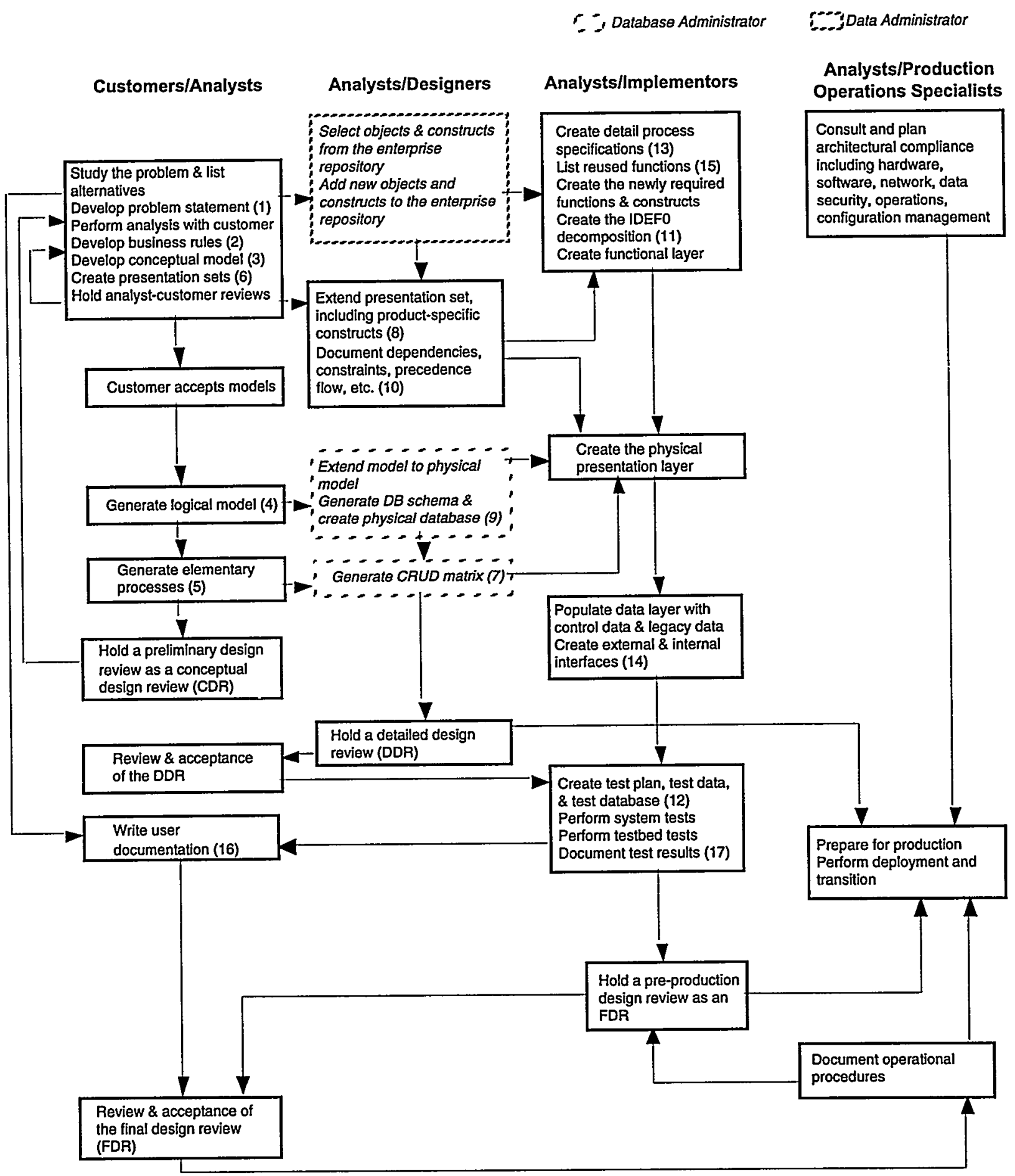


References

1. IEEE Software Engineering Standards, Third Edition, IEEE, 1989.

2. Sandia Software Guidelines, Volume 1, Software Quality Planning, SAND85-2344, August 1987.

3. Sandia Software Guidelines, Volume 2, Documentation, SAND85-2345, in press.

4. Sandia Software Guidelines, Volume 3, Standards, Practices, and Conventions, SAND85-2346, July 1986.

5. Sandia Software Guidelines, Volume 4, Configuration Management, SAND85-2347, June 1992.

6. Sandia Software Guidelines, Volume 5, Tools, Techniques, and Methodologies, SAND85-2348, July 1989.

7. Software Development Process Methodology, Sandia, June 23, 1993.

8. SLP 1011, Software Management, April 1993.

9. SLP 2815, Preferred Processes, December 1992.

10. Computer Software Management, DOE Order 1330.1D, Office of Information Resources Management, U.S. Department of Energy, Washington, D.C., May 1992.

11. Becker, Steve D. Annotated Summary of the Information Model Design Procedure (IMDP), SAND94-0460, May 1994.

12. Nijssen, G.M. and Halpin, T.A. Conceptual Schema and Relational Database Design. Prentice Hall, 1989.

13. Nijssen, G.M. "The Essence of Universal Informatics." Class given in Albuquerque, New Mexico, July 1992.

14. Nijssen, G.M. and Twine, S.M. "A Summary of the Conceptual Schema Design Procedure (CSDP)." Nijssen Adviesbureau voor Informatica, 1990.

15. Nijssen, G.M. and Twine, S.M. “A Framework for Information System Development Methodologies." Nijssen Adviesbureau voor Informatica, 1990.

16. Organization 13316. "Department 13316 Home Page." Sandia Web, IRN. http://sass902d.itd.sandia.gov/Dept13316_Home.html

17. Organization 13316. "Natural-language Information Analysis Methodology (NIAM)." Sandia Web, IRN. http://sass902d.itd.sandia.gov/Niam/NiamIntro.html

18. Organization 13000. "Information Architecture." Sandia Web, IRN. http://www_irn.sandia.gov/organization/div13000/ctr 13200/dpt13202/ouia_94.htm

19. Myers, Glenford J. Art of Software Testing. John Wiley and Sons, 1979.

20. Software and Information Life Cycle (SILC) for the Integrated Information Services Organization; Analysis and Implementation Phase Adaptations of the Sandia Software Guidelines: Issue A. SAND95-1614, July 1995. 
21. Wybolt, Nicholas. Frameworks for CASE Tool Integrations: IPSE Development. Proceedings of the Digital Equipment Computer Users Society, Spring 1990.

22. Booch, Grady. "Practical Software Engineering." Crosstalk, July 1995.

23. Fleischmann, Albert. Distributed Systems: Software Design and Implementation. Springer-Verlag, 1994.

24. DeMarco, T. and Lister, T. Peopleware: Productive Projects and Teams. Dorset House, 1979. 


\section{Acknowledgments}

\section{Contributors-Issue $A$ and $B$ Teams}

Duane Garrison

Jim Stromberg

Andrea Cassidy

David Cuyler

John K. Sharp

Ronald Hall

Mary Lynn Clark

Scott Joyce

Irene Thurston

Donna S. Eaton

John Hatley

Shelley Eaton

Joe Schofield

Gary E. Rivord

Fay Tamashiro

Greg Conrad

Elisa Kephart

Charlene Strickland

Dwayne Knirk

Al Alvarado

Carol Jones

Mike Pendley

Bill Mertens

T. C. Adams

Nancy Marsh
Administrative Systems

Administrative Systems

Administrative Systems

Data Administration

Data Administration

Data Administration

Electronic Commerce

Information Technologies

Information Technologies

Information Technologies

Information Technologies

Information Technologies

Information Technologies

Information Technologies

Information Technologies

Information Technologies

Information Technologies

Information Technologies

Software Quality

Program Management

Program Management

Test Bed System

Database Administration

Production Services

The Production Process 


\section{Glossary of Terms}

Table 4 Glossary

\begin{tabular}{|c|c|}
\hline Term & Definition \\
\hline $4 G L$ & Fourth Generation Language \\
\hline CASE & Computer-Aided Software Engineering \\
\hline $\begin{array}{l}\text { Change management } \\
\text { Configuration } \\
\text { management }\end{array}$ & $\begin{array}{l}\text { A discipline applying technical and administrative direction and } \\
\text { surveillance to identify and document the functional and } \\
\text { physical characteristics of a configuration item, control } \\
\text { changes to those characteristics, record and report change } \\
\text { processing and implementation status, and verify compliance } \\
\text { with specified requirements }\end{array}$ \\
\hline $\mathrm{ClO}$ & Corporate Information Officer \\
\hline $\begin{array}{l}\text { Conceptual Design } \\
\text { Review }\end{array}$ & $\begin{array}{l}\text { CDR; A review to verify the conceptual information model } \\
\text { created through interactions with customers for completeness, } \\
\text { logical integrity, and validity. Also discussed will be the } \\
\text { traceable path from the conceptual model to targeted physical } \\
\text { data stores, either existing or new. The conceptual model must } \\
\text { be capable of being expressed with structured English } \\
\text { sentences with concrete examples provided for validation. } \\
\text { Fact by Fact mapping to screens, reports, and databases will } \\
\text { be examined. Mappings of facts (data attributes) to middle } \\
\text { layer functions will also be presented. Algorithms used to } \\
\text { derive new facts will be reviewed, and targeted } \\
\text { implementation strategies will be discussed. Proof of the } \\
\text { customers' acceptance of the model must exist at this time. }\end{array}$ \\
\hline Conceptual schema & $\begin{array}{l}\text { A formal specification of the user's information requirements; a } \\
\text { common world model that explicitly defines the set of } \\
\text { meaningful sentences which can be communicated via } \\
\text { machine, or stored within the machine }\end{array}$ \\
\hline Constraint & $\begin{array}{l}\text { Defines a restriction on the permitted population(s) of one or } \\
\text { more populatable constructs in a conceptual schema }\end{array}$ \\
\hline Context Diagram & $\begin{array}{l}\text { The highest level data flow diagram, depicting the system's } \\
\text { interfaces to other systems within the enterprise and its } \\
\text { interfaces to the outside world; defines the scope and } \\
\text { boundary for the system. It represents the system as a single } \\
\text { circle, hiding all information about what occurs within the } \\
\text { system. Each external entity is depicted as a single square. } \\
\text { These squares, and the flows into and out of them, define the } \\
\text { context within which the system must operate. Arrows drawn } \\
\text { between the system and each external entity depict flows; they } \\
\text { are labeled with the names of objects that flow into the system } \\
\text { from the external entity and that flow out from the system to } \\
\text { the external entity. }\end{array}$ \\
\hline
\end{tabular}


Table 4 Glossary (Continued)

\begin{tabular}{|c|c|}
\hline Term & Definition \\
\hline CRUD & Create, Read, Update, Delete \\
\hline csu & Customer Service Unit \\
\hline Customer & The internal or external buyer or recipient of a product \\
\hline DCE & Distributed Computing Environment \\
\hline Detailed Design Review & $\begin{array}{l}\text { DDR; To review the implementation information model. The } \\
\text { implementation model may include implementation-specific } \\
\text { facts (such as surrogate keys, internal objects, etc.) used to } \\
\text { optimize physical implementation. Full compliance of the } \\
\text { physical structures to the model specifications will be } \\
\text { reviewed. Any constraints implemented in the schema will be } \\
\text { tested. Specific use of data by the functional layer will be } \\
\text { reviewed. Production support/operation documents should } \\
\text { exist. }\end{array}$ \\
\hline DOE & Department of Energy \\
\hline ERD & $\begin{array}{l}\text { Entity Relationship Diagram; A data model that describes } \\
\text { attributes of entities and the relationships among them }\end{array}$ \\
\hline Evolutionary prototype & $\begin{array}{l}\text { A preliminary instance of a system, usually with limited } \\
\text { interfaces and functionality, that serves as a starting point for } \\
\text { continued development of a system until that system exists in } \\
\text { its fully implemented form. In contrast to an exploratory } \\
\text { prototype, an evolutionary prototype becomes an integral part } \\
\text { of the delivered product. }\end{array}$ \\
\hline Fact & $\begin{array}{l}\text { A piece of information with specific meaning, communicated in } \\
\text { a formal natural language sentence }\end{array}$ \\
\hline Final Design Review & $\begin{array}{l}\text { FDR; The final opportunity to review the deliverables prior to } \\
\text { deployment in a production status. Assure that all test bed } \\
\text { anomalies have been resolved. All issues of support (CSU and } \\
\text { Production Operations) should be resolved. }\end{array}$ \\
\hline FIPS & Federal Information Processing Standard \\
\hline Functional diagrams & Graphic depictions of functional components of a system \\
\hline ICAM & $\begin{array}{l}\text { Integrated Computer-Aided Manufacturing; a definition } \\
\text { language }\end{array}$ \\
\hline IDEF & $\begin{array}{l}\text { Integrated Computer-Aided Manufacturing Definition; } \\
\text { designated government standards, FIPS } 183 \text { and } 184\end{array}$ \\
\hline IDEF0 & $\begin{array}{l}\text { Part of the IDEF set of standards; widely used method for } \\
\text { graphically describing how a process works that uses } \\
\text { functional decomposition to provide both an overall picture and } \\
\text { a detailed view of the process }\end{array}$ \\
\hline
\end{tabular}


Table 4 Glossary (Continued)

\begin{tabular}{|c|c|}
\hline Term & Definition \\
\hline IDEF1X & $\begin{array}{l}\text { Part of the IDEF set of standards; an entity-relationship } \\
\text { diagramming standard }\end{array}$ \\
\hline IEEE & $\begin{array}{l}\text { Institute of Electrical and Electronics Engineers-an } \\
\text { organization of engineering and electronics professionals; } \\
\text { notable for developing standards relating to software } \\
\text { engineering }\end{array}$ \\
\hline IIS & Integrated Information Services \\
\hline Implementation & $\begin{array}{l}\text { The process of converting a software design into executable } \\
\text { code }\end{array}$ \\
\hline Methodology & $\begin{array}{l}\text { A set of measurable core process definitions to be applied to } \\
\text { software developed at Sandia }\end{array}$ \\
\hline Metric & $\begin{array}{l}\text { A quantitative measure to the degree to which a system, } \\
\text { component, or process possesses a given attribute }\end{array}$ \\
\hline NIAM & Natural-language Information Analysis Methodology \\
\hline Project management & $\begin{array}{l}\text { The processes by which projects are administered from } \\
\text { conceptualization through maintenance and retirement }\end{array}$ \\
\hline Pseudocode & $\begin{array}{l}\text { A combination of programming language constructs and } \\
\text { natural language used to express a computer program design }\end{array}$ \\
\hline Quality assurance & $\begin{array}{l}\text { - A planned and systematic pattern of all actions necessary } \\
\text { to provide adequate confidence that an item or product } \\
\text { conforms to established technical requirements } \\
\text { - A set of activities designed to evaluate the process by } \\
\text { which products are developed or manufactured }\end{array}$ \\
\hline SDD & $\begin{array}{l}\text { Software Design Description-A representation of software } \\
\text { created to facilitate analysis, planning, implementation, and } \\
\text { decision making; used for communication of software design } \\
\text { information, and may be thought of as a blueprint or model of } \\
\text { the system }\end{array}$ \\
\hline SLP 1011 & Sandia Laboratories Policy for Software Management \\
\hline Software engineering & $\begin{array}{l}\text { The application of a systematic, disciplined, quantifiable } \\
\text { approach to the development, operation, and maintenance of } \\
\text { software }\end{array}$ \\
\hline $\begin{array}{l}\text { Software Management } \\
\text { Plan }\end{array}$ & $\begin{array}{l}\text { An auditable mechanism of each individual software group; } \\
\text { describes the methods, tools, and techniques to acquire, } \\
\text { develop and document, use, and support the software under } \\
\text { the stewardship of that group. Development methodology } \\
\text { documents and conduct of operations manuals are often the } \\
\text { mechanisms used to document the Plan. The Software Quality } \\
\text { Department distributes templates of the Plan. }\end{array}$ \\
\hline
\end{tabular}


Table 4 Glossary (Continued)

\begin{tabular}{|c|c|}
\hline Term & Definition \\
\hline $\begin{array}{l}\text { Software Management } \\
\text { Program }\end{array}$ & $\begin{array}{l}\text { Provides guidance and assistance to Sandia groups in } \\
\text { established policies, process analysis, and preparation of } \\
\text { Software Management Plans; administered by the Sandia } \\
\text { Software Quality Department in response to DOE Order } \\
1330.1 C \text { requirements that Sandia properly manage its } \\
\text { software assets. }\end{array}$ \\
\hline SRS & $\begin{array}{l}\text { Software Requirements Specification-Documentation of the } \\
\text { essential requirements (functions, performance, design } \\
\text { constraints, and attributes) of the software and its external } \\
\text { interfaces }\end{array}$ \\
\hline Standards & $\begin{array}{l}\text { Mandatory requirements employed and enforced to prescribe } \\
\text { a disciplined and uniform approach to software development; } \\
\text { Mandatory conventions and practices }\end{array}$ \\
\hline Structure charts & $\begin{array}{l}\text { Graphic depictions of the invocation control of modules which } \\
\text { comprise a software system }\end{array}$ \\
\hline Test database & $\begin{array}{l}\text { An exact replica of a production database, created for testing } \\
\text { purposes }\end{array}$ \\
\hline Verification & $\begin{array}{l}\text { The process of evaluating a system or component to } \\
\text { determine whether the products of a given development phase } \\
\text { satisfy the conditions imposed at the start of that phase }\end{array}$ \\
\hline
\end{tabular}




\section{Appendix A}

\section{Example of Deliverable Set to Complete the Analysis, Design, and Implementation Phases and to Use at the Design Reviews}

This example from the Network Database Project includes Deliverables 1 through 17, to demonstrate the deliverable set (considered the minimum critical set) for the analysis, design, and implementation phases of a software development project.

We chose this example because it is a real system, currently in development. It will probably be implemented by the time the SILC document is published. As a teaching tool, it uses concepts familiar to all computer users at Sandia, namely User IDs and accounts on those computer systems for which access has been approved.

This network database contains extensive network and security management concepts, which have been left out of our example to simplify the content to a manageable size for both the reader and the authors. As shown in the Problem Statement and Context Diagram, the concepts demonstrated are all aspects of the customer and logins/ accounts, plus the report, "Reauthorization Forms."

Only customers who are Sandia employees are considered here. The entire Network Database specifications are available in the corporate repository. For information about access to the repository, contact the Data Administration Department or the Corporate Computer Help Desk at 845-2243. The browsable functions, currently in development, will be available to any Sandian through the internal Web. 


\section{Problem Statement}

\section{Deliverable 1}

The problem statement contains a problem narrative, a textual deliverable that states the business problem in concise terms. A context diagram shows the scope of the system and which objects flow between the system and an external system interface. A high-level function diagram shows the decomposition of the system into major sub-processes. Large problems should be decomposed into subsystems that can be defined in two to three pages each.

\section{Problem Statement-Purpose}

The intent of a problem statement is to establish an initial and mutually acceptable understanding between the analyst and the customer(s) as to the nature and scope of the system. It establishes a boundary (fuzzy, to be sure) to the capabilities of the system. It gives the analyst a starting point for determining the major components of the system. It also launches the customer/analyst modeling sessions to clarify and verify all information and processes that the customer will require and agree to own.

The problem statement has value beyond the development period. It is a project resource that can and should be reused in socializing and training for application of the system; it is a good introduction for user manuals. Versions of this statement should be maintained to keep it current with the system "as built."

\section{Content Guide}

The problem statement should include:

- A high-level, simplified description of the major functions the system is to perform, its boundaries, and its interfaces

- Identification of users and operators, including their departmental (individual) business or operations

- Description of phasing if intended (large or complex systems may be developed in several phases). 


\section{Problem Narrative-Version 1}

\section{Deliverable 1}

The Network Database is the framework for administering an enterprise-wide information system consisting of distributed computers and groups and multiple levels of networks. It covers these major functions:

- Accounts-Keeps track of "customers" authorized to access Sandia networks or any centrally managed services on those networks. In this sense a "customer" is anyone who has a legitimate need to access Sandia networks, whether they are Sandians or not, and whether they are U.S. citizens or not.

- Networks-Keeps track of Sandia's overall network configuration, including all of the logical LANs defined under the four major protocols "TCP/IP," "Appletalk," "DECNET," and "IPX," the placement of those logical LANs on physical LANs and networks, and all machine connections to those logical and physical LANs.

- Security Plans-Provides a means to create and manage machine security plans. Also, manages and create portions of the major security plans that cover physical LANs, networks, and multi-user machines.

These major functions, and the user groups that perform them, are described in more detail in Table 1. The functions describe the complete system, to be developed in two phases.

Note: The shaded functions represent the focus of this example, all pertaining to the accounts function.

Table 1 Network Database Functions by User Group

\begin{tabular}{|ll|}
\hline \multicolumn{1}{|c|}{ User Group } & \multicolumn{1}{c|}{ Function } \\
\hline Password Administration & Registration of customers \\
& Generation of Login Names and Unix user IDs \\
& Registration of corporate-level central services \\
& Setting up customers and entity accounts on central services \\
& Expiration and reauthorization of accounts \\
& Placement of customers in NWDB user groups \\
& Registration of entities \\
& Setting up customer membership in named Unix groups \\
& Registration of physical LANs and logical LANs \\
& Administration of control information conceming user groups, countries, sites, e- \\
& mail types, and classification ranks \\
\hline $\begin{array}{l}\text { NWDB Administrators } \\
\text { (LAN Points of Contact) }\end{array}$ & Management of LAN connection information \\
& Management of basic machine information \\
& Registration of LAN-level central services \\
& Setting up customers and entity accounts on LAN central services \\
&
\end{tabular}


Table 1 Network Database Functions by User Group (Continued)

\begin{tabular}{|c|c|}
\hline User Group & Function \\
\hline & Verification of LAN points of contact \\
\hline \multirow[t]{4}{*}{ Customer Service Units } & Maintenance of desktop configuration information \\
\hline & Management of LAN connection information \\
\hline & Management of basic machine information \\
\hline & Generation of CSU charges \\
\hline \multirow[t]{4}{*}{ Central Service Administrators } & Maintenance of central service accounts \\
\hline & Administration of control information concerning Internet domains \\
\hline & Feeding Sandia's Domain Name Servers \\
\hline & Registration of Cryptographic Public Keys \\
\hline Network Analysts & General network troubleshooting \\
\hline \multirow[t]{4}{*}{ Network Design Team } & Management of LAN connection information \\
\hline & Management of basic machine information \\
\hline & Network troubleshooting \\
\hline & ISN Control Files \\
\hline \multirow{5}{*}{$\begin{array}{l}\text { Computer Security } \\
\text { Administrators }\end{array}$} & Management of major security plans \\
\hline & Verification of Security Officers \\
\hline & Approval and release of machine security plans \\
\hline & Registration of Computer Security Representatives \\
\hline & $\begin{array}{l}\text { Administration of control information concerning security plan approvers, security } \\
\text { managers, protection methods, sensitivity categories, security officer titles, and } \\
\text { major security plan categories }\end{array}$ \\
\hline \multirow{3}{*}{$\begin{array}{l}\text { Computer Security } \\
\text { Representatives }\end{array}$} & Preparation of machine security plans \\
\hline & Maintenance of LAN connection information \\
\hline & Maintenance of basic machine information \\
\hline $\begin{array}{l}\text { Physical Security } \\
\text { Administrators }\end{array}$ & Registration of Vaults \\
\hline \multirow[t]{2}{*}{ E-Mail Support } & Registration of E-Mail Post Offices \\
\hline & Generation of Login Names for the LIS System \\
\hline \multirow{2}{*}{$\begin{array}{l}\text { Network Database } \\
\text { Administrators }\end{array}$} & General troubleshooting \\
\hline & $\begin{array}{l}\text { Administration of control information conceming networks, security environments, } \\
\text { network interface types, tech control centers, protocols, TCP/P network } \\
\text { implementations, vendors, machine makes and types, operating systems, and } \\
\text { network functions }\end{array}$ \\
\hline
\end{tabular}




\section{The following functions have been chosen for detailed treatment} to demonstrate the software life cycle:

\section{Password Administration}

\section{Registration of Customers}

People who are in the Human Resources file automatically have much of their data reflected into the Network Database, but certain data, such as country of citizenship, Sandia sponsor, and network access expiration date must be entered by hand even if the customer is in Human Resources. For people who are not in the Human Resources file, including "visitors" from throughout the world, Password Administration registers all data. There are currently 9,256 Sandians (8,527 regular and 729 non-regular, all of which are in Human Resources), 3,083 contractors (of which 2,214 are in Human Resources), and 487 visitors (none of which are in Human Resources), listed as active in the Network Database.

\section{Generation of Login Names and Unix User IDs}

The "Login Name" (such as "meaton" or "mjmurph") is now in use throughout Sandia to identify users on computerized systems, and is also a standard part of everyone's e-mail address. For accounts on Unix systems, Login Names are paired with numeric Unix User IDs, with different aspects of the Unix account controlled by one or the other. The Network Database contains an algorithm to generate unique Login Names and Unix User IDs (up to three pairs for each person or entity-one pair each for the unclassified, confidential, and secret classification levels). Generation of unclassified Login Names and Unix User IDs is done automatically for people in the Human Resources file when they become active employees. All other such generation is hand-initiated by Password Administration. There are currently 14,328 active pairs of Login Names and Unix User IDs in the Network Database.

\section{Registration of corporate-level central services}

"Corporate-level central services" are major computing resources and services to which access can be restricted by password, and for which it has been decided that Password Administration will formally control access.

When each service is registered, the highest classification rank allowed is recorded, whether or not it is available for access by named Unix groups, whether or not it requires file disposition for terminated accounts, whether or not it requires a case for account charges, and where it is located as far as what server machines, physical LANs, and/or networks on which it is available.

\section{Setting up customer and entity accounts on central services}

Password administration uses the Network Database to set up accounts on central services they manage before they give out passwords. (Passwords are generated outside the Network Database.) 
The Network Database applies numerous rules to make sure that account data is complete and that a given customer's access to a service does not violate security considerations before an account may be activated.

If the service requires a case number for account charges, it is entered here and checked against the list of valid cases in HRIS.

There are currently 9,382 active corporate-level accounts.

\section{Expiration and reauthorization of accounts}

The Network Database determines the expiration date of accounts held by any customer or entity based on a number of factors such as the classification level of the accounts, a contractor's expiration date, a visitor's access expiration date, and so on. When it is time for a set of accounts belonging to a customer or entity to expire, the system will generate a Reauthorization Form, which is automatically delivered via e-mail to the account holder or entity owner if an entity. The customer can then print it out, get it signed, and return it to set the account expiration dates ahead. 


\section{Context Diagram}

\section{Deliverable 1}

This shows the scope of the system and which objects flow between the system and an external system interface. Dashed lines indicate business actions not covered in this example set.

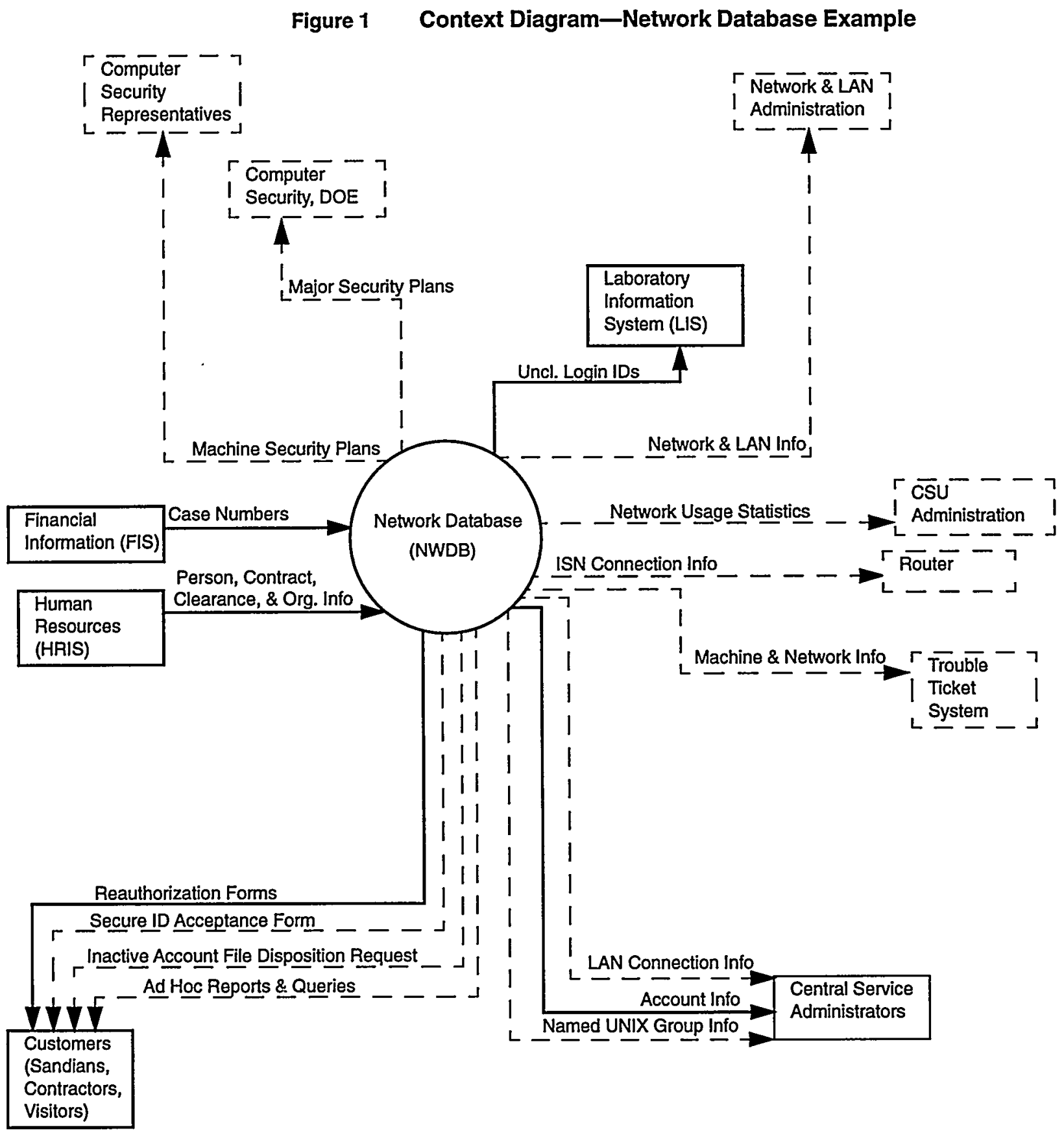




\section{High-Level Function Diagram}

\section{Deliverable 1}

This example shows the major functions of the NWDB. This depicts the central part of Figure 1 on page A-7.

Figure 2 Node A-0, Network Database Example

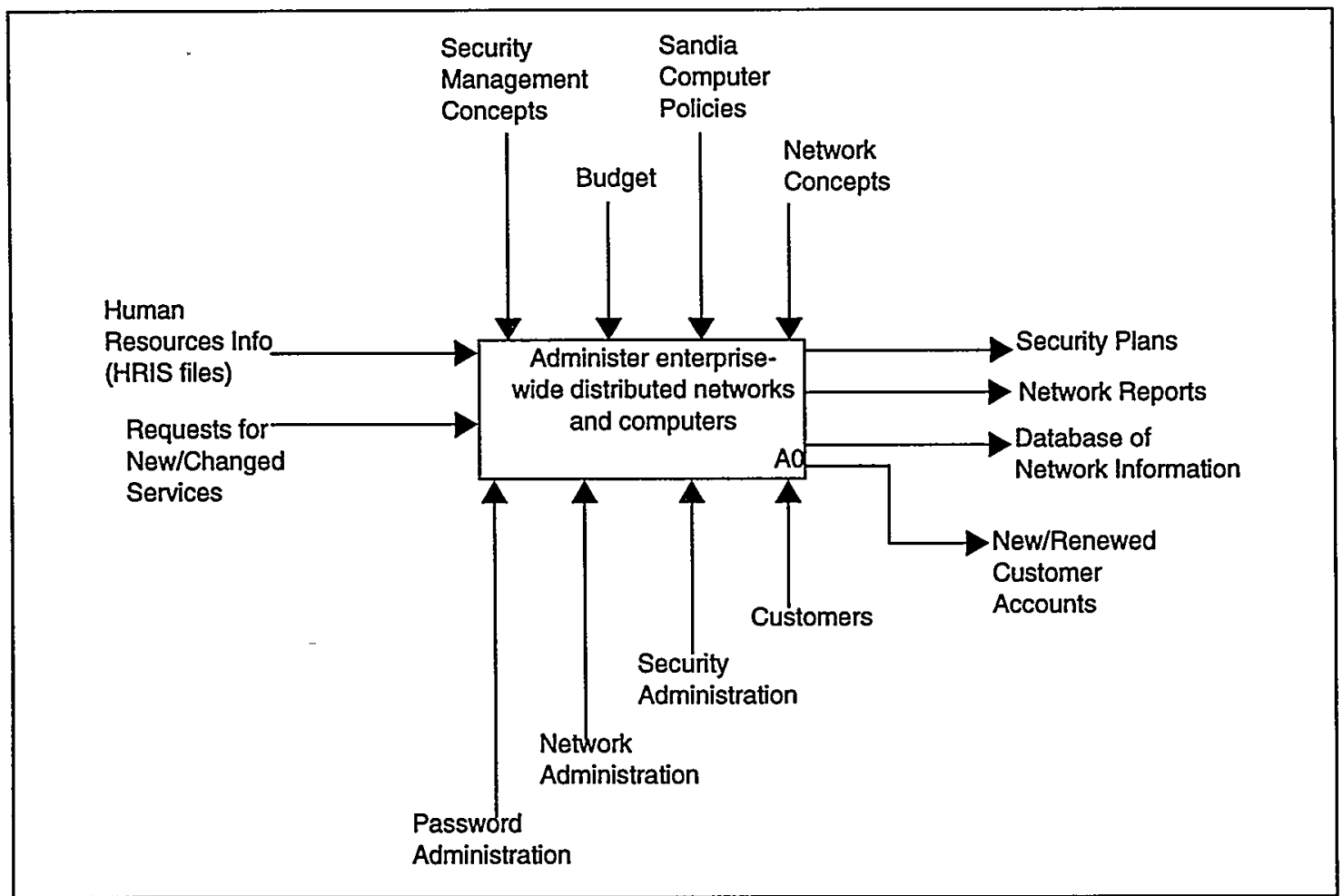

Reading from the top, clockwise:

- The arrows entering the top of the box containing the process description show "controls" on this process.

- The arrows exiting to the left show the outputs

- The bottom arrows show mechanisms, i.e., answers to who or what will act on this process

- Finally the arrows entering from the right show those inputs that will be affected by the processes and transformed to an output 


\section{Business Rules}

\section{Deliverable 2}

Formal natural language sentences with examples specify aspects of each object to be maintained in the information system. These sentences, together with initial storyboards or cartoons and flow diagrams, are also used to document the business rules and verify them with the customer. The initial storyboards or cartoons and flow diagrams with process and event information (not shown here) are refined throughout the analysis and design processes into Deliverable 6, presentation sets with event and process lists (see "Presentation Sets" on page A-25). General constraints and derivation rules are included in textual form or as a reference to the process list.

The formal natural language sentences with examples require an object listing with definitive information about each object. The listing includes the object's label, along with examples.

Note: We prefer that a minimum of three examples be supplied. Where the Network Database team had only two examples, this generated list simply displays <<a value $>$.

This example extracts specific information from the NWDB. To view the complete deliverable for this subset of the NWDB, see the World Wide Web:

http:// sass902d.itd.sandia.gov/SILCExam.pdf

Table 2 Object and Fact Type Listing, With Examples

\begin{tabular}{|c|c|}
\hline Object Type & Example Sentence \\
\hline \multirow[t]{3}{*}{ Account } & Central_Service <LIS > has access authorized for Login $<<a$ value $>>$ \\
\hline & Central_Service $<L I S>$ has access authorized for Login <jschavez> \\
\hline & Central_Service $<$ SOMNET $>$ has access authorized for Login $<$ dbblack $>$ \\
\hline \multirow[t]{3}{*}{ Agent } & Customers identifies a(n) Agent \\
\hline & agent_ID $<H R$ update $>$ identifies a(n) Agent \\
\hline & agent_ID <New IRN/NWDB Accts > identifies a(n) Agent \\
\hline \multirow[t]{3}{*}{ Case } & Case_Nbr $<33214000000>$ identifies $a(n)$ Case \\
\hline & Case_Nbr $<89991110000>$ identifies a(n) Case \\
\hline & Case_Nbr $<<a$ value $>$ identifies a(n) Case \\
\hline \multirow[t]{3}{*}{ Central_Service } & Short_Name $<<a$ value $>$ identifies a(n) Central_Service \\
\hline & Short_Name <LIS $>$ identifies a(n) Central_Service \\
\hline & Short_Name <SOMNET> identifies a(n) Central_Service \\
\hline \multirow[t]{3}{*}{ Clearance } & Clearance_type $<L>$ identifies a(n) Clearance \\
\hline & Clearance_type $<Q>$ identifies a(n) Clearance \\
\hline & Clearance_type <none $>$ identifies a(n) Clearance \\
\hline \multirow[t]{3}{*}{ Customer } & identifies a(n) Customer \\
\hline & jidentifies a(n) Customer \\
\hline & identifies $a(n)$ Customer \\
\hline
\end{tabular}


Table 2 Object and Fact Type Listing, With Examples

\begin{tabular}{|c|c|}
\hline Object Type & Example Sentence \\
\hline \multirow[t]{3}{*}{ Entity } & Entity_ID $<000031000>$ identifies a(n) Entity \\
\hline & Entity_ID $<000032007>$ identifies a(n) Entity \\
\hline & Entity_ID $<<$ a value $>$ identifies a(n) Entity \\
\hline FT225 & Account <LIS,dbblack> had status last changed by Agent_Type $<<a$ value $>>$ \\
\hline FT225 & Account <LIS, mfjohnson> had status last changed by Agent_Type <process> \\
\hline FT225 & Account $<$ SOMNET,jschavez $>$ had status last changed by Agent_Type $<<$ a value $>>$ \\
\hline FT226 & Account $<$ LIS, dbblack $>$ charges by default to Case $<<$ a value $>$ \\
\hline FT226 & Account $<$ LIS, mfjohnson $>$ charges by default to Case $<33214000000>$ \\
\hline FT226 & Account $<S O M N E T$, jschavez $>$ charges by default to Case $<<a$ value $>>$ \\
\hline FT227 & Account $<$ LIS, dbblack $>$ had its status last changed by Agent $<<$ a value $>>$ \\
\hline FT227 & Account <LIS, mfjohnson> had its status last changed by Agent <New IRN/NWDB Accts> \\
\hline FT227 & Account $<$ SOMNET,jschavez $>$ had its status last changed by Agent $<\quad$ Customer \\
\hline FT228 & Account $<$ LIS,dbblack $>$ had its status last changed on Date_Time $<<a$ value $>>$ \\
\hline FT228 & Account <LIS,mfjohnson> had its status last changed on Date_Time $<198812110545>$ \\
\hline FT228 & Account $<S O M N E T$,jschavez $>$ had its status last changed on Date_Time $<<$ a value $>$ \\
\hline FT229 & Account $<$ LIS, dbblack $>$ is accepted on Date $<<a$ value $>$ \\
\hline FT229 & Account $<$ LIS, mfjohnson $>$ is accepted on Date $<19941521>$ \\
\hline FT229 & Account <SOMNET,jschavez> is accepted on Date $<19931203>$ \\
\hline FT230 & Account $<$ LIS, dbblack $>$ is marked with Status $<<a$ value $>>$ \\
\hline FT230 & Account $<$ LIS, mfjohnson $>$ is marked with Status <inactive $>$ \\
\hline FT230 & Account $<$ SOMNET,jschavez $>$ is marked with Status $<<a$ value $>$ \\
\hline FT231 & Customer $<286449007>$ had status last changed by Agent $<<a$ value $>>$ \\
\hline FT231 & Customer $<399886113>$ had status last changed by Agent $<$ New IRN/NWDB Accts $>$ \\
\hline FT231 & Customer $<576447650>$ had status last changed by Agent $<$ \\
\hline FT232 & Customer $<286449007>$ had status last changed by Agent_Type <<a value $>$ \\
\hline FT232 & Customer $<399886113>$ had status last changed by Agent_Type <process $>$ \\
\hline FT232 & Customer $<576447650>$ had status last changed by Agent_Type <<a value $>$ \\
\hline
\end{tabular}




\section{Conceptual Information Model}

\section{Deliverable 3}

The primary components of Deliverable 3 are the constrained sentences in textual form and in a natural language model diagram. These communicate analysis results concisely to the designer.

"Information systems are systems which support the effective communication of meaningful information between human beings by design. If these information systems are to be truly effective, then the principles governing their construction and use must be derived from the principles of human communication and not from the principles of computerized data processing. Our most fundamental axiom is:

Information systems are systems which support the communication of linguistic sentences (called facts) between humans.

“... in order to restrict ourselves to the effective communication of meaningful information via these information systems we must define a formal representation of the common world model to be shared by the computer and the human. This common world model is called a conceptual schema. For the human user, the conceptual schema explicitly defines the set of meaningful sentences which can be communicated via the machine (or, for that matter, can be stored within the machine). For the computer, the conceptual schema explicitly defines the permitted states of the database contents and the permitted transitions between those states." (Reference 14; see "References" on page 20).

Sentences and their constraints in textual form (facts) follow. 


\section{Constrained Sentences}

\section{Deliverable 3}

Table 3 Objects-NWDB Example

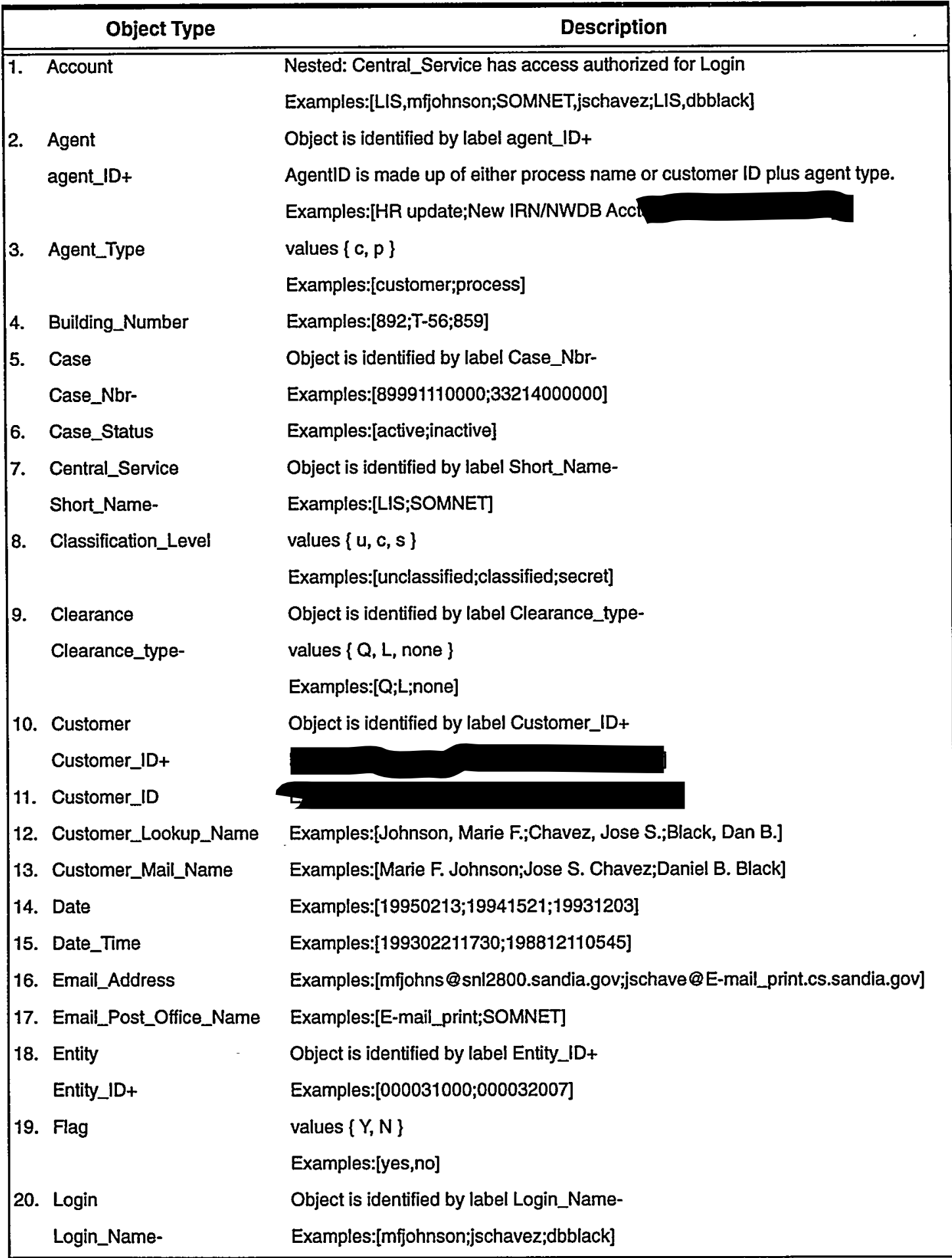




\section{Table 3 Objects-NWDB Example (Continued)}

\begin{tabular}{|c|c|c|}
\hline & Object Type & Description \\
\hline & Login_Holder & Object is identified by label Login_Holder_ID+ \\
\hline & Login_Holder_ID+ & Examples: $[5$ \\
\hline \multirow[t]{2}{*}{22.} & Login_Holder_Type & values $\{$ customer, entity $\}$ \\
\hline & & Examples:[customer;entity] \\
\hline 23. & Mail_Stop_Number & Examples:[0661;0330;0933] \\
\hline \multirow[t]{2}{*}{24.} & NWDB_User_Group & Object is identified by label User_Group_Title- \\
\hline & User_Group_Title- & $\begin{array}{l}\text { Examples:[router;NWDB Administrator;Password Administrator;Computer } \\
\text { Security Administrator] }\end{array}$ \\
\hline \multirow[t]{2}{*}{25.} & Organization & Object is identified by label Org_Nbr- \\
\hline & Org_Nbr- & Examples:[13211;02811;04000] \\
\hline 26. & Phone_Number & Examples:[5058443333;5102945555;5058452222] \\
\hline \multirow[t]{2}{*}{27.} & Reference_Record & Object is identified by label Ref_Rcd_Key- \\
\hline & Ref_Rcd_Key- & Examples:[30035;30036;30037] \\
\hline 28. & Room_Number & Examples:[M100;268;L400] \\
\hline 29. & SecurlD_Card_Serial_Nbr & Examples:[ \\
\hline & Site & Object is identified by label Site_code- \\
\hline & Site_code- & Examples:[SA,SC] \\
\hline 31. & Site_Desc & Examles:[Sandia Labs, NM; Sandia Labs, CA] \\
\hline & Status & Object is identified by label status_code- \\
\hline & status_code- & values $\{a, i\}$ \\
\hline & & Examples:[active;inactive] \\
\hline 33. & Unix_User_ID & Examples:[12001;18003;30035] \\
\hline
\end{tabular}

Table 4 Facts-NWDB Example

\begin{tabular}{|llll|}
\hline \multicolumn{1}{|c}{ Fact Type } & \multicolumn{1}{c|}{ Mandatory Object } & \multicolumn{1}{c|}{ Unique Object } \\
\hline \hline 1. & Account had status last changed by Agent_Type & Account & Account \\
2. & Account charges by default to Case & -- & Account \\
3. & Account had its status last changed by Agent & Account & Account \\
4. & Account had its status last changed on Date_Time & Account & Account \\
5. & Account is accepted on Date & -- & Account \\
6. & Account is marked with Status & Account & Account \\
7. & Customer had status last changed by Agent & Customer & Customer \\
8. Customer changed by Agent_Type & Customer & Customer \\
9. Case is statused by Case_Status & Case & Case \\
10. Central_Service has access authorized for Login & -- & Central_Service + Login \\
11. Customer can be reached at Phone_Number & - & Customer \\
\hline
\end{tabular}


Table 4 Facts-NWDB Example (Continued)

\begin{tabular}{|c|c|c|c|}
\hline & Fact Type & Mandatory Object & Unique Object \\
\hline 12. & Customer holds Clearance & Customer & Customer \\
\hline 13. & Customer is identified by Customer_Lookup_Name & Customer & Customer \\
\hline 14. & Customer is identified by Customer_Mail_Name & Customer & Customer \\
\hline 15. & Account is originally set up by Customer & -- & Account \\
\hline 16. & $\begin{array}{l}\text { Customer receives electronic mail through } \\
\text { Email_Post_Office_Name }\end{array}$ & - & Customer \\
\hline 17. & Customer receives faxes at Phone_Number & -- & Customer \\
\hline 18. & $\begin{array}{l}\text { Customer receives hard-copy mail at } \\
\text { Mail_Stop_Number }\end{array}$ & -- & Customer \\
\hline 19. & Customer works at Site & - & Customer \\
\hline 20. & Customer works for Organization & -- & Customer \\
\hline 21. & Customer works in Building_Number & -- & Customer \\
\hline 22. & Customer works in Room_Number & - & Customer \\
\hline 23. & $\begin{array}{l}\text { Reference_Record has as last used for a customer a } \\
\text { Customer_ID }\end{array}$ & Reference_Record & Reference_Record \\
\hline 24. & Account has its card expire on Date & - & Account \\
\hline 25. & Customer had status last changed on Date_Time & Customer & Customer \\
\hline 26. & Account has file disposition made Flag & -- & Account \\
\hline 27. & Customer holds a login as flagged by Flag & Customer & Customer \\
\hline 28. & Entity flagged as holding a login by Flag & Entity & Entity \\
\hline 29. & Customer has registered in hr system Flag & Customer & Customer \\
\hline 30. & Login changed by Agent_Type & Login & Login \\
\hline 31. & Login had its status last changed by Agent & Login & Login \\
\hline 32. & Login had its status last changed on Date_Time & Login & Login \\
\hline 33. & Login has its accounts expire on Date & -- & Login \\
\hline 34. & Login holds Login_Holder & Login & Login \\
\hline \multirow[t]{2}{*}{35.} & Login is given Unix_User_ID & Login & Login \\
\hline & & - & Unix_User_ID \\
\hline 36. & Login is held in level Classification_Level & Login & Login \\
\hline 37. & Login is marked with Status & Login & Login \\
\hline 38. & Login is typed by Login_Holder_Type & Login & Login \\
\hline 39. & $\begin{array}{l}\text { NWDB_User_Group can be contacted in ca through } \\
\text { Mail_Stop_Number }\end{array}$ & -- & NWDB_User_Group \\
\hline 40. & $\begin{array}{l}\text { NWDB_User_Group can be contacted in nm through } \\
\text { Mail_Stop_Number }\end{array}$ & -- & NWDB_User_Group \\
\hline 41. & NWDB_User_Group contains Customer & -- & $\begin{array}{l}\text { NWDB_User_Group + } \\
\text { Customer }\end{array}$ \\
\hline 42. & NWDB_User_Group is ca contact for Email_Address & -- & NWDB_User_Group \\
\hline & $\begin{array}{l}\text { NWDB_User_Group is nm contact for } \\
\text { Email_Address }\end{array}$ & -- & NWDB_User_Group \\
\hline
\end{tabular}


Table 4 Facts-NWDB Example (Continued)

$\therefore$

\begin{tabular}{|c|c|c|c|}
\hline & Fact Type & Mandatory Object & Unique Object \\
\hline 44. & $\begin{array}{l}\text { NWDB_User_Group can be contacted in ca through } \\
\text { Organization }\end{array}$ & -- & NWDB_User_Group \\
\hline 45. & $\begin{array}{l}\text { NWDB_User_Group can be contacted in } \mathrm{nm} \text { through } \\
\text { Organization }\end{array}$ & - & NWDB_User_Group \\
\hline 46. & $\begin{array}{l}\text { NWDB_User_Group can be contacted in ca through } \\
\text { Phone_Number }\end{array}$ & - & NWDB_User_Group \\
\hline 47. & $\begin{array}{l}\text { NWDB_User_Group can be faxed to in ca at } \\
\text { Phone_Number }\end{array}$ & -- & NWDB_User_Group \\
\hline 48. & $\begin{array}{l}\text { NWDB_User_Group can be contacted in nm through } \\
\text { Phone_Number }\end{array}$ & -- & NWDB_User_Group \\
\hline 49. & $\begin{array}{l}\text { NWDB_User_Group can be faxed to in nm at } \\
\text { Phone_Number }\end{array}$ & -- & NWDB_User_Group \\
\hline \multirow[t]{2}{*}{50.} & SecurlD_Card_Serial_Nbr is authorized by Account & - & SecurlD_Card_Serial_Nbr \\
\hline & & -- & Account \\
\hline 51. & Site is described by Site_Desc & Site & Site \\
\hline 52. & Customer is marked with Status & Customer & Customer \\
\hline 53. & $\begin{array}{l}\text { Reference_Record has as last used for a customer a } \\
\text { Unix_User_ID }\end{array}$ & Reference_Record & Reference_Record \\
\hline 54. & $\begin{array}{l}\text { Reference_Record has as last used for an entity a } \\
\text { Unix_User_ID }\end{array}$ & Reference_Record & Reference_Record \\
\hline
\end{tabular}




\section{Natural Language Model Diagram}

\section{Deliverable 3}

We show two pages of Natural-language Information Analysis Methodology (NIAM) models, which is one form of a conceptual model in diagram form. This diagram provides the designer with another view that demonstrates the data relationships and data roles.

Notes: * denotes a "derived fact."

The FTxx numbers shown in the diagram reference those defined in the formal natural language sentences in Deliverable 2. 


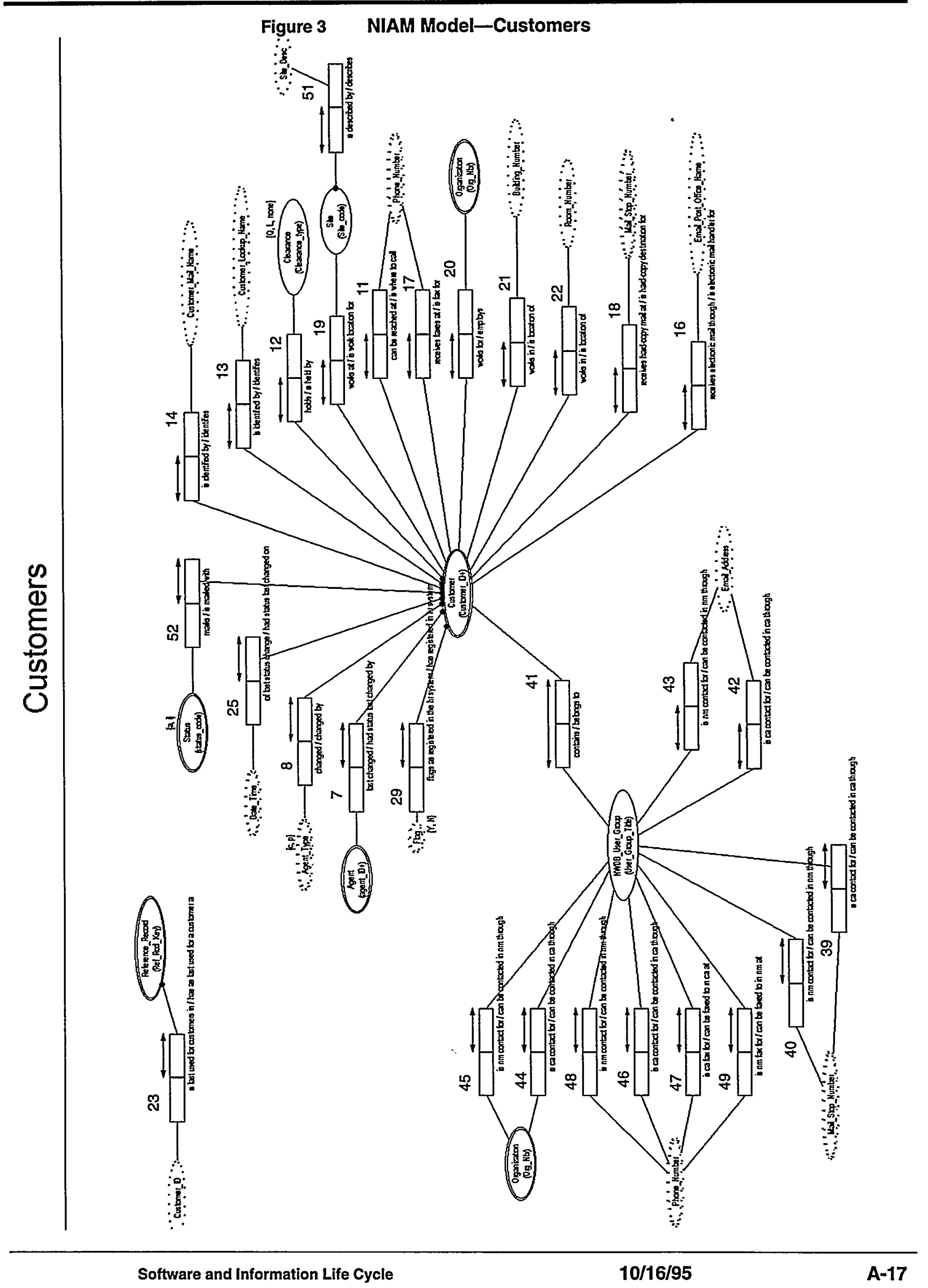




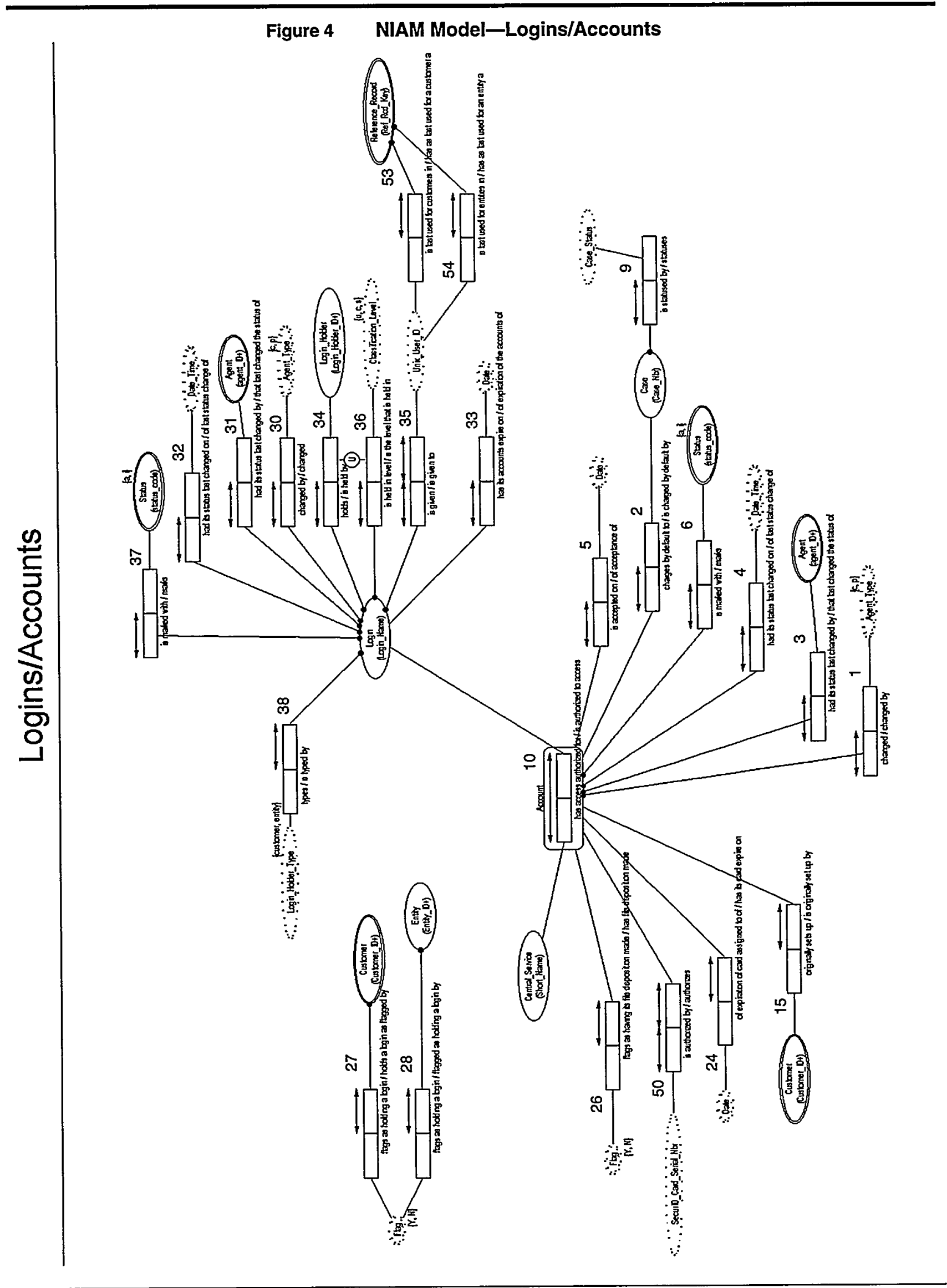




\section{Logical Information Model-IDEF1X Diagram}

\section{Deliverable 4}

The logical database structure (without vendor software or implementation considerations) is documented with a diagram of the form used in IDEF1X (a FIPS representation of an ER model). This diagram shows the objects and attributes with foreign key relationships.

The IDEF1X format shown here is a standard chosen for government agencies.

Note: Keys are listed first in each table with a line following the last item in the key. Data items which uniquely identify an object are usually the primary key. The following describes the symbols used in an IDEF1X diagram.

PKxx

AKxx

FKXX

Parent

Child

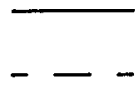

Primary key; key that uniquely identifies one object from another

Alternate key; a secondary identifier

Foreign key; key of another entity when it migrates into a given entity as a result of a relationship between the two entities

An entity on the 1-end of a 1-to-many relationship

An entity on the many end of a 1-to-many relationship Identifying relationships (foreign key is part of primary key)

Non-identifying relationships (foreign key is not part of primary key)

Cardinality

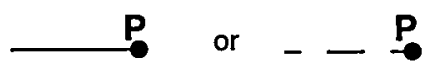

$\mathbf{z}_{0}$ or $-\underline{z}_{0}$

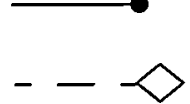

The quantifier in a relationship between two entities; a quantifier answers the question, "How many?"

Existence of at least one matching child required if parent exists (1: 1 or more)

Existence of maximum of one child matching parent (1: 0 or 1$)$

1: 0 or more

Parent-child relationship where the parent entity is optional (i.e., optional non-identifying relationship) 
Figure 5

NWDB IDEF1X Logical Model
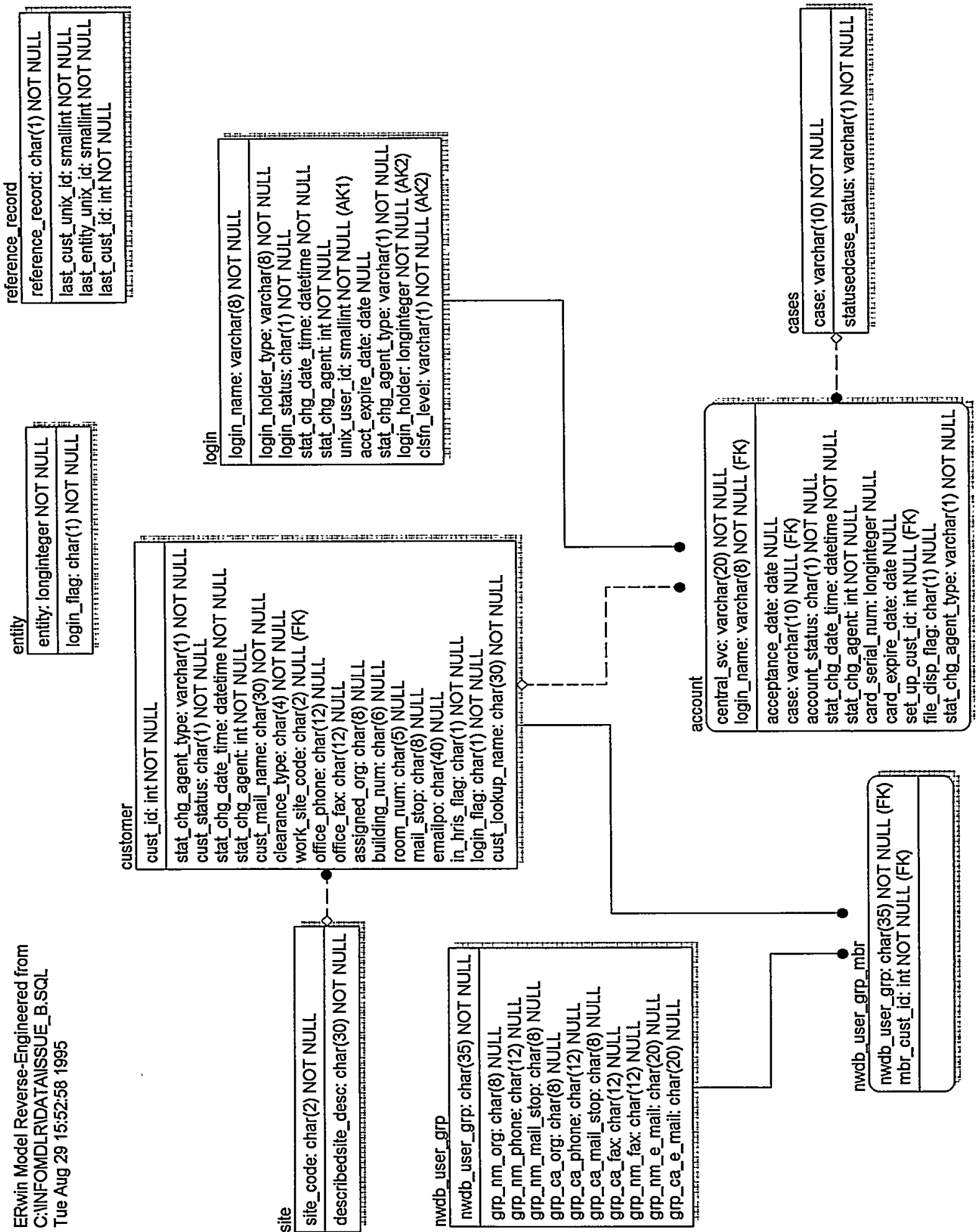

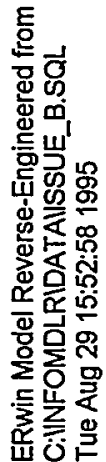
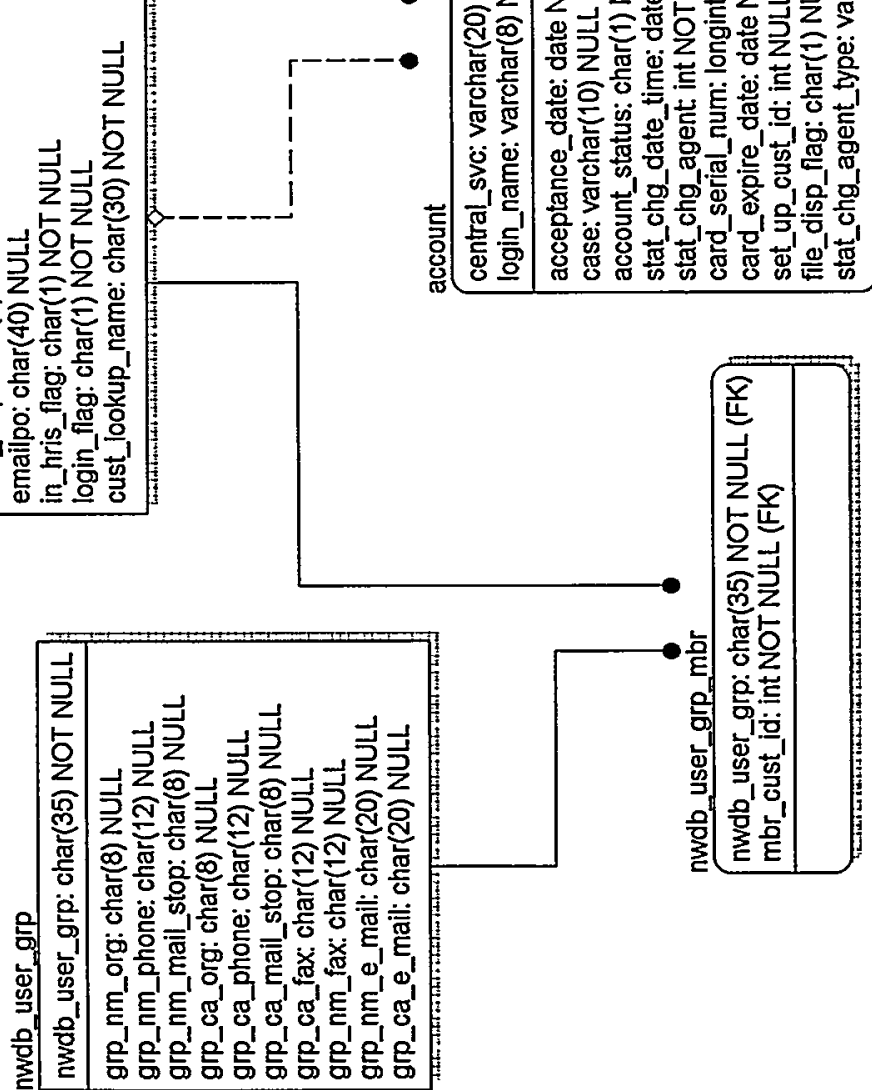


\section{Elementary Processes}

\section{Deliverable 5}

Elementary processes represent the smallest units of work which can be executed to modify the content of the information base and which will leave the information base in a state consistent with integrity rules.

The elementary processes in the example define the Create/Update/Delete (CUD) processes used on each core object. They can be generated from the Information Model, and they form the basis for the CRUD matrix in Deliverable 7 (see "CRUD Matrix" on page A-35). They also form the basis for analyzing the processes by beginning and ending state and recording the changes made to the data by a person or automated system.

Notes: * items are processes which include the enforcement of the mandatory relationships among tables, shown in Deliverable 4 (see "Logical Information ModelIDEF1X Diagram" on page A-19). However, the following example demonstrates no mandatory relationships among tables.

This example is for the tables of the NWDB. They demonstrate the elementary processes by table.

This example extracts specific information from the NWDB. To view the complete deliverable for this subset of the NWDB, see the World Wide Web:

http:// sass902d.itd.sandia.gov/SILCExam.pdf

Notes: The Optional column notes Null Allowed. The following describes the Data Entry designation:

md Mixed determination - both the user and other data supplied by the system are involved in changing the data

derived Only the system may change the data, using a "derivation rule"

user A person enters or modifies the data without using other data from the database (also called strict determination) 


\section{Elementary Processes}

Table 5 CUD Actions by Table

\begin{tabular}{|c|c|c|c|}
\hline CUD/Table Row & Optional & Data Entry & Comments \\
\hline \multicolumn{4}{|l|}{ customer } \\
\hline cust_id & & derived & system-generated key \\
\hline stat_chg_agent_type & & derived & system-generated key \\
\hline cust_status & & md & user/pick list \\
\hline stat_chg_date_time & & derived & system clock \\
\hline stat_chg_agent & & derived & \\
\hline cust_mail_name & & user/HRIS & \\
\hline clearance_type & & user/HRIS & \\
\hline work_site_code & $\checkmark$ & $\mathrm{md} / \mathrm{HRIS}$ & user/pick list site.site_code \\
\hline office_phone & $\checkmark$ & user/HRIS & \\
\hline office_fax & $\checkmark$ & user/HRIS & \\
\hline assigned_org & $\checkmark$ & user/HRIS & \\
\hline building_num & $\checkmark$ & user/HRIS & \\
\hline room_num & $\checkmark$ & user/HRIS & \\
\hline mail_stop & $\checkmark$ & user/HRIS & \\
\hline emailpo & $\checkmark$ & user/HRIS & \\
\hline in_hris_flag & & derived & \\
\hline login_flag & & derived & \\
\hline $\begin{array}{l}\text { cust_lookup_name } \\
\text { account }\end{array}$ & & derived & \\
\hline central_svc & & md & pick list \\
\hline login_name & & md & pick list from login table \\
\hline acceptance_date & $\checkmark$ & user & \\
\hline case & $\checkmark$ & HRIS/FIS & \\
\hline account_status & & md & pick list \\
\hline stat_chg_date_time & & derived & system clock \\
\hline stat_chg_agent & & derived & administrator login \\
\hline card_serial_num & $\checkmark$ & user & \\
\hline card_expire_date & $\checkmark$ & user & \\
\hline set_up_cust_id & $\checkmark$ & user & \\
\hline file_disp_flag & $\checkmark$ & md & pick list \\
\hline stat_chg_agent_type & & derived & administrator type \\
\hline \multicolumn{4}{|l|}{ login } \\
\hline login_name & & md & system-generated/user-modified \\
\hline
\end{tabular}


Table 5 CUD Actions by Table (Continued)

\begin{tabular}{|c|c|c|c|}
\hline CUD/Table Row & Optional & Data Entry & Comments \\
\hline login_holder_type & & md & pick list \\
\hline login_status & & md & pick list \\
\hline stat_chg_date_time & & derived & system clock \\
\hline stat_chg_agent & & derived & administrator login \\
\hline unix_user_id & & md & system-generated/user-modified \\
\hline acct_expire_date & $\checkmark$ & user & \\
\hline stat_chg_agent_type & & derived & administrator type \\
\hline login_holder & & user & \\
\hline clsfin_level & & md & pick list \\
\hline nwdb_user_grp & & & \\
\hline nwdb_user_grp & & user & \\
\hline grp_nm_org & $\checkmark$ & user & \\
\hline grp_nm_phone & $\checkmark$ & user & \\
\hline grp_nm_mail_stop & $\checkmark$ & user & \\
\hline grp_ca_org & $\checkmark$ & user & \\
\hline grp_ca_phone & $\checkmark$ & user & \\
\hline grp_ca_mail_stop & $\checkmark$ & user & \\
\hline grp_ca_fax & $\checkmark$ & user & \\
\hline grp_nm_tax & $\checkmark$ & user & \\
\hline grp_nm_e_mail & $\checkmark$ & user & \\
\hline $\begin{array}{l}\text { grp_ca_e_mail } \\
\text { nwdb_user_grp_mbr }\end{array}$ & $\checkmark$ & user & \\
\hline nwdb_user_grp_mbr & & md & assign customer as member of nwdb group pick list \\
\hline $\begin{array}{l}\text { mbr_cust_id } \\
\text { cases }\end{array}$ & & md & pick list/validation=customer table \\
\hline case & & HRIS/FIS & case must be valid case number from this list \\
\hline $\begin{array}{l}\text { statusedcase_status } \\
\text { site }\end{array}$ & & md & pick list \\
\hline site_code & & md & site code must be validated from this list \\
\hline $\begin{array}{l}\text { describedsite_desc } \\
\text { entity }\end{array}$ & & user & \\
\hline entity & & user & \\
\hline login_flag & & md & pick list \\
\hline
\end{tabular}


Table 5 CUD Actions by Table (Continued)

\begin{tabular}{|c|c|c|c|}
\hline CUD/Table Row & Optional & Data Entry & Comments \\
\hline \multicolumn{4}{|l|}{ reference_record } \\
\hline reference_record & & derived & system-generated keys \\
\hline last_cust_unix_id & & derived & system-generated keys \\
\hline last_entity_unix_id & & derived & system-generated keys \\
\hline last_cust_id & & derived & system-generated keys \\
\hline
\end{tabular}




\section{Presentation Sets}

\section{Deliverable 6}

Presentation sets consist of one Process/Actor State Transition Matrix per core entity (usually represented by a table), the completed storyboard diagrams, and the event and process lists:

- The Process/Actor State Transition Matrix (PAST) will add rigorous definitions of the processes related to each presentation set or object. In addition, from the customer's viewpoint, it helps integrate the actions performed and the state of the information system for each elementary process.

-The analyst first draws up a rough draft of the matrices and then confirms them with all the customers. It is this process of confirming the matrices that adds value of using PAST. Matrices that have not been confirmed with the customer will clarify few concepts.

- Completed storyboard diagrams with annotated sets denoting groups of data items to be treated as a single unit (as in elementary processes). Standard templates, when available, will be applied to provide a consistent "look and feel" with other systems. Diagrams may be hand-drawn initially, to help the customers view their data and how they will enter data into the computer. Other diagrams will enable the customers to think about their data and how they want to use it, i.e., reports, screen displays, graphs, etc. The application development software or other vendor software may be used, starting the prototyping processes early in the customeranalyst dialogues. 


\section{Process/Actor State Transition Matrix}

Deliverable 6

Description

- One matrix for each major database entity, or each major object (see "Logical Information Model-IDEF1X Diagram" on page A-19)

- One column for each major actor (actors can be people or software modules/ systems)

- One row for each major customer or system task (each thing that can happen to the entity/object)

- Column for Beginning state (status) on the left; Ending state (status) on the right

- Not every row results in a state (status) change

- Cells show what each actor does

Uses

- Help customers and developers understand the system

- Help define the requirements

- Help think through business needs

- Provide systematic, structured framework for process analysis

- Get more detail in specifications

- Help all parties communicate about requirements and specifications

- Capture knowledge about the system for managers, customers, future maintainers

Inputs Needed

- Context diagram

- Core requirements (more may be found later)

- Core data entities (more may be found later)

- List of players (actors)

- List of tasks or events

- List of processes

\section{Skills/Guidelines for Writing}

- Listen

- Understand customers' needs

- Communicate clearly in writing, with precision and conciseness

-Use customer's terminology

-Avoid computer jargon

-Avoid methodology's jargon 
Table 6 Customer Process/Actor State Transition Matrix (Valid Status List: Null, Active, Inactive)

\begin{tabular}{|c|c|c|c|c|c|c|c|c|c|c|}
\hline $\begin{array}{l}\text { Object } \\
\text { Life Cycle } \\
\text { Event } \\
\text { (Task) }\end{array}$ & $\begin{array}{l}\text { Beginning } \\
\text { State }\end{array}$ & Actions Tak & en-By Bus & Iness Functi & & & & & $\begin{array}{l}\text { Elementary } \\
\text { Processes }\end{array}$ & $\begin{array}{l}\text { Ending } \\
\text { State }\end{array}$ \\
\hline & $\begin{array}{c}\text { Incoming } \\
\text { Status }\end{array}$ & $\begin{array}{l}\text { Line Org } \\
\text { Individual }\end{array}$ & HRIS & $\begin{array}{l}\text { NWDB } \\
\text { Admin }\end{array}$ & $\begin{array}{l}\text { Password } \\
\text { Admin }\end{array}$ & $\begin{array}{l}\text { LAN } \\
\text { POC }\end{array}$ & $\begin{array}{l}\text { Security } \\
\text { System }\end{array}$ & $\begin{array}{c}\text { NWDB } \\
\text { Application } \\
\text { Program }\end{array}$ & & $\begin{array}{c}\text { Resulting } \\
\text { Status }\end{array}$ \\
\hline $\begin{array}{l}\text { Create } \\
\text { customer } \\
\text { from HRIS } \\
\text { upload file }\end{array}$ & Null & $n / a$ & \begin{tabular}{|l|} 
Sends \\
batch \\
upload \\
files \\
(Changes \\
file 5 \\
nights a \\
week; Big \\
file every \\
Friday)
\end{tabular} & $n / a$ & $n / a$ & $n / a$ & $n / a$ & \begin{tabular}{|l|} 
If customer \\
does not \\
exist, \\
creates \\
customer, \\
generates e- \\
mail name, \\
generates \\
lookup \\
name, \\
generates \\
UNIX User \\
ID, sets \\
in_HRIS \\
flag to Yes
\end{tabular} & \begin{tabular}{|l} 
Reads \\
customer \\
Creates \\
customer
\end{tabular} & \begin{tabular}{|l|} 
If edits \\
pass \\
Active \\
If edits fail \\
Null
\end{tabular} \\
\hline $\begin{array}{l}\text { Create } \\
\text { customer } \\
\text { on NWDB } \\
\text { online } \\
\text { screen }\end{array}$ & Null & \begin{tabular}{|l} 
Submits \\
User ID \\
Request \\
Form
\end{tabular} & $n / a$ & $\begin{array}{l}\text { Accesses } \\
\text { screen; } \\
\text { creates } \\
\text { customer }\end{array}$ & $\begin{array}{l}\text { Accesses } \\
\text { screen; } \\
\text { creates } \\
\text { customer }\end{array}$ & n/a & $n / a$ & $\begin{array}{l}\text { If customer } \\
\text { does not } \\
\text { exist, } \\
\text { creates } \\
\text { customer, } \\
\text { generates e- } \\
\text { mail name, } \\
\text { generates } \\
\text { lookup } \\
\text { name, } \\
\text { generates } \\
\text { UNIX User } \\
\text { ID, sets } \\
\text { in_HRIS } \\
\text { flag to no }\end{array}$ & \begin{tabular}{|l} 
Reads \\
customer \\
Creates \\
customer
\end{tabular} & Active \\
\hline $\begin{array}{l}\text { Display } \\
\text { customer } \\
\text { info online }\end{array}$ & \begin{tabular}{|l} 
Active or \\
Inactive
\end{tabular} & $\begin{array}{l}\text { Accesses } \\
\text { NWDB } \\
\text { screen }\end{array}$ & n/a & $\begin{array}{l}\text { Accesses } \\
\text { NWDB } \\
\text { screen }\end{array}$ & $\begin{array}{l}\text { Accesses } \\
\text { NWDB } \\
\text { screen }\end{array}$ & $\begin{array}{l}\text { Access } \\
\text { es } \\
\text { NWDB } \\
\text { screen }\end{array}$ & $\begin{array}{l}\text { Computer } \\
\text { Security } \\
\text { accesses } \\
\text { NWDB } \\
\text { screen }\end{array}$ & \begin{tabular}{|l} 
Accesses \\
all related \\
tables to get \\
customer \\
info
\end{tabular} & \begin{tabular}{|l} 
Reads \\
customer
\end{tabular} & $\begin{array}{l}\text { Active or } \\
\text { Inactive }\end{array}$ \\
\hline $\begin{array}{l}\text { Reactivate } \\
\text { customer } \\
\text { online }\end{array}$ & Inactive & $\begin{array}{l}\text { May place } \\
\text { phone call } \\
\text { to NWDB } \\
\text { Admin or } \\
\text { Password } \\
\text { Control }\end{array}$ & $n / a$ & $\begin{array}{l}\text { Reactivates } \\
\text { status }\end{array}$ & $\begin{array}{l}\text { Reactivates } \\
\text { status }\end{array}$ & $n / a$ & $n / a$ & $\begin{array}{l}\text { Enforces } \\
\text { edits; } \\
\text { Changes } \\
\text { customer } \\
\text { info }\end{array}$ & $\begin{array}{l}\text { Reads } \\
\text { customer } \\
\text { Updates } \\
\text { customer }\end{array}$ & Active \\
\hline
\end{tabular}


Table 6 Customer Process/Actor State Transition Matrix (Valid Status List: Null, Active, Inactive) (Continued)

\begin{tabular}{|c|c|c|c|c|c|c|c|c|c|c|}
\hline \multirow[t]{2}{*}{$\begin{array}{l}\text { Object } \\
\text { Life Cycle } \\
\text { Event } \\
\text { (Task) }\end{array}$} & \multirow{2}{*}{\begin{tabular}{|c}
$\begin{array}{c}\text { Beginning } \\
\text { State }\end{array}$ \\
$\begin{array}{c}\text { incoming } \\
\text { Status }\end{array}$
\end{tabular}} & \multicolumn{7}{|c|}{ Actions Taken-By Business Function } & \multirow[t]{2}{*}{$\begin{array}{l}\text { Elementary } \\
\text { Processes }\end{array}$} & \multirow{2}{*}{$\begin{array}{c}\begin{array}{c}\text { Ending } \\
\text { State }\end{array} \\
\begin{array}{c}\text { Resulting } \\
\text { Status }\end{array}\end{array}$} \\
\hline & & $\begin{array}{l}\text { Line Org } \\
\text { Individual }\end{array}$ & HRIS & $\begin{array}{l}\text { NWDB } \\
\text { Admin }\end{array}$ & $\begin{array}{l}\text { Password } \\
\text { Admin }\end{array}$ & $\begin{array}{l}\text { LAN } \\
\text { POC }\end{array}$ & $\begin{array}{l}\text { Security } \\
\text { System }\end{array}$ & $\begin{array}{l}\text { NWDB } \\
\text { Application } \\
\text { Program }\end{array}$ & & \\
\hline $\begin{array}{l}\text { Reactivate } \\
\text { customer } \\
\text { from HRIS } \\
\text { upload file }\end{array}$ & Inactive & $n / a$ & \begin{tabular}{|l|} 
Sends \\
batch \\
upload \\
files \\
(Changes \\
file 5 \\
nights a \\
week; Big \\
file every \\
Friday
\end{tabular} & $n / a$ & $n / a$ & $n / a$ & $n / a$ & \begin{tabular}{|l|} 
Enforces \\
edits; \\
Changes \\
customer \\
info
\end{tabular} & \begin{tabular}{|l|} 
Reads \\
customer \\
Updates \\
customer
\end{tabular} & Active \\
\hline \begin{tabular}{|l|} 
Deactivate \\
customer
\end{tabular} & Active & $n / a$ & $n / a$ & $\begin{array}{l}\text { Reads } \\
\text { report of } \\
\text { inactives, } \\
\text { greater than } \\
1 \text { year }\end{array}$ & \begin{tabular}{|l|} 
Reads \\
report of \\
inactives, \\
greater \\
than 1 year
\end{tabular} & n/a & n/a & $\begin{array}{l}\text { Changes } \\
\text { status of } \\
\text { customer }\end{array}$ & \begin{tabular}{|l}
$\begin{array}{l}\text { Reads } \\
\text { customer }\end{array}$ \\
Updates \\
customer
\end{tabular} & Inactive \\
\hline $\begin{array}{l}\text { Deactivate } \\
\text { customer } \\
\text { from HRIS } \\
\text { Update File }\end{array}$ & Active & no & \begin{tabular}{|l} 
Sends \\
batch \\
upload \\
files \\
(Changes \\
file 5 \\
nights a \\
week; Big \\
file every \\
Friday
\end{tabular} & n/a & n/a & na & n/a & $\begin{array}{l}\text { Changes } \\
\text { status of } \\
\text { customer }\end{array}$ & $\begin{array}{l}\text { Reads } \\
\text { customer } \\
\text { Updates } \\
\text { customer }\end{array}$ & Inactive \\
\hline $\begin{array}{l}\text { Update } \\
\text { customer } \\
\text { from HRIS } \\
\text { Update File }\end{array}$ & Active & $n / a$ & $\begin{array}{l}\text { Sends } \\
\text { batch } \\
\text { upload } \\
\text { files } \\
\text { (Changes } \\
\text { file 5 } \\
\text { nights a } \\
\text { week; Big } \\
\text { file every } \\
\text { Friday }\end{array}$ & $n / a$ & $n / a$ & $n / a$ & $n / a$ & \begin{tabular}{|l|} 
Enforces \\
edits; \\
Changes \\
customer \\
info
\end{tabular} & \begin{tabular}{|l|}
$\begin{array}{l}\text { Reads } \\
\text { customer }\end{array}$ \\
Updates \\
customer
\end{tabular} & Active \\
\hline \begin{tabular}{|l} 
Report \\
customers \\
with \\
inactive \\
status \\
greater \\
than 1 year
\end{tabular} & & This task is & reported on & the login entity & & & & & & \\
\hline \begin{tabular}{|l|} 
Report \\
customers \\
withexpired \\
logins
\end{tabular} & & This task is & reported on & the login entity & & & & & & \\
\hline
\end{tabular}




\section{Table 6 Customer Process/Actor State Transition Matrix} (Valid Status List: Null, Active, Inactive) (Continued)

\begin{tabular}{|c|c|c|c|c|c|c|c|c|c|c|}
\hline \multirow[t]{2}{*}{$\begin{array}{c}\text { Object } \\
\text { Lilfe Cycle } \\
\text { Event } \\
\text { (Task) }\end{array}$} & \multirow{2}{*}{$\begin{array}{c}\text { Beginning } \\
\text { State } \\
\begin{array}{c}\text { Incoming } \\
\text { Status }\end{array}\end{array}$} & \multicolumn{7}{|c|}{ Actions Taken-By Business Function } & \multirow[t]{2}{*}{$\begin{array}{r}\text { Elementary } \\
\text { Processes }\end{array}$} & \multirow{2}{*}{$\begin{array}{c}\begin{array}{c}\text { Ending } \\
\text { State }\end{array} \\
\text { Resulting } \\
\text { Status }\end{array}$} \\
\hline & & $\begin{array}{c}\text { Line Org } \\
\text { Individual }\end{array}$ & HRIS & $\begin{array}{l}\text { NWDB } \\
\text { Admin }\end{array}$ & $\begin{array}{l}\text { Password } \\
\text { Admin }\end{array}$ & $\begin{array}{l}\text { LAN } \\
\text { POC }\end{array}$ & $\begin{array}{c}\text { Security } \\
\text { System }\end{array}$ & $\begin{array}{c}\text { NWDB } \\
\text { Application } \\
\text { Program }\end{array}$ & & \\
\hline $\begin{array}{l}\text { Assign } \\
\text { customer } \\
\text { to NWDB } \\
\text { User } \\
\text { Groups }\end{array}$ & & \multicolumn{7}{|c|}{ This task is reported on the NWDB User Group } & & \\
\hline $\begin{array}{l}\text { Assign } \\
\text { customers } \\
\text { to a login } \\
\text { holder }\end{array}$ & & \multicolumn{7}{|c|}{ This task is reported on the login entity } & & \\
\hline $\begin{array}{l}\text { Generate e- } \\
\text { mall } \\
\text { address \& } \\
\text { pass to } \\
\text { HRIS }\end{array}$ & $\begin{array}{l}\text { Active or } \\
\text { Inactive }\end{array}$ & $n / a$ & $\begin{array}{l}\text { Receives } \\
\text { e-mail } \\
\text { address } \\
\text { and } \\
\text { updates } \\
\text { HRIS }\end{array}$ & $n / a$ & $n / a$ & $n / a$ & $n / a$ & \begin{tabular}{|l|} 
Reads all \\
new/ \\
updated \\
customers; \\
Creates e- \\
mail \\
addresses; \\
Builds file for \\
HRIS
\end{tabular} & $\begin{array}{l}\text { Reads } \\
\text { customer } \\
\text { Update } \\
\text { customer }\end{array}$ & $\begin{array}{l}\text { Active or } \\
\text { Inactive }\end{array}$ \\
\hline $\begin{array}{l}\text { Delete } \\
\text { customer }\end{array}$ & Inactive & $n / a$ & $\mathrm{n} / \mathrm{a}$ & $\begin{array}{l}\text { Reads } \\
\text { report of } \\
\text { deleted } \\
\text { customers }\end{array}$ & $\begin{array}{l}\text { Reads } \\
\text { report of } \\
\text { deleted } \\
\text { customers }\end{array}$ & $n / a$ & $n / a$ & \begin{tabular}{|l|} 
Deletes \\
customer \\
who has \\
been \\
inactive \\
more than 1 \\
year
\end{tabular} & $\begin{array}{l}\text { Deletes } \\
\text { customer }\end{array}$ & Null \\
\hline \begin{tabular}{|l|} 
Process \\
SecurlD \\
acceptance \\
forms
\end{tabular} & & \multicolumn{7}{|c|}{ Outside the project's scope } & & \\
\hline \begin{tabular}{|l|} 
Create \\
customer \\
from online \\
screen \\
(only for \\
contractors \\
$\&$ visitors) \\
\end{tabular} & & \multicolumn{7}{|c|}{ Outside the project's scope } & & \\
\hline $\begin{array}{l}\text { Update } \\
\text { customer's } \\
\text { cryptogra- } \\
\text { phic public } \\
\text { key }\end{array}$ & & \multicolumn{7}{|c|}{ Outside the project's scope } & & \\
\hline
\end{tabular}


Table 7 Logins Process/Actor State Transition Matrix (Valid Status List: Null, Active, Inactive)

\begin{tabular}{|c|c|c|c|c|c|c|c|c|c|c|}
\hline \multirow[t]{2}{*}{$\begin{array}{l}\text { Object Life } \\
\text { Cycle } \\
\text { Event } \\
\text { (Task) }\end{array}$} & \multirow{2}{*}{\begin{tabular}{|c}
$\begin{array}{c}\text { Beginning } \\
\text { State }\end{array}$ \\
$\begin{array}{c}\text { Incoming } \\
\text { Status }\end{array}$
\end{tabular}} & \multicolumn{7}{|c|}{ Actions Taken-By Business Function } & \multirow[t]{2}{*}{$\begin{array}{l}\text { Elementary } \\
\text { Processes }\end{array}$} & \multirow{2}{*}{\begin{tabular}{|c}
$\begin{array}{c}\text { Ending } \\
\text { State }\end{array}$ \\
$\begin{array}{c}\text { Resulting } \\
\text { Status }\end{array}$
\end{tabular}} \\
\hline & & $\begin{array}{l}\text { Line Org } \\
\text { Individual }\end{array}$ & HRIS & $\begin{array}{l}\text { NWDB } \\
\text { Admin }\end{array}$ & $\begin{array}{l}\text { Password } \\
\text { Admin }\end{array}$ & $\begin{array}{l}\text { LAN } \\
\text { POC }\end{array}$ & $\begin{array}{l}\text { Security } \\
\text { System }\end{array}$ & $\begin{array}{c}\text { NWDB } \\
\text { Application } \\
\text { Program }\end{array}$ & & \\
\hline \begin{tabular}{|l|} 
Create login \\
name from \\
HRIS \\
upload file
\end{tabular} & Null & $n / a$ & $\begin{array}{l}\text { Sends } \\
\text { batch } \\
\text { upload } \\
\text { files } \\
\text { (Changes } \\
\text { file } 5 \\
\text { nights a } \\
\text { week; Big } \\
\text { file every } \\
\text { Friday) }\end{array}$ & $n / a$ & $n / a$ & $n / a$ & $n / a$ & \begin{tabular}{|l|} 
If login does \\
not exist, \\
creates a \\
login
\end{tabular} & $\begin{array}{l}\text { Reads login } \\
\text { Creates } \\
\text { login }\end{array}$ & \begin{tabular}{|l} 
If edits \\
pass \\
Active \\
If edits fail \\
Null
\end{tabular} \\
\hline \begin{tabular}{|l|} 
Assign \\
customer a \\
login name \\
for each \\
classification \\
lovel
\end{tabular} & Null & $\begin{array}{l}\text { Submits } \\
\text { request } \\
\text { form for } \\
\text { confidential } \\
\text { and secret }\end{array}$ & $n / a$ & $\begin{array}{l}\text { Assigns } \\
\text { login holder } \\
\text { \& login } \\
\text { holder type }\end{array}$ & $\begin{array}{l}\text { Assigns } \\
\text { login holder } \\
\text { \& login } \\
\text { holder type }\end{array}$ & $n / a$ & $n / a$ & \begin{tabular}{|l} 
Enforces \\
edits \\
(validates \\
clearance \\
against \\
Physical \\
Security \\
clearance \\
file)
\end{tabular} & $\begin{array}{l}\text { Reads login } \\
\text { Creates } \\
\text { login }\end{array}$ & $\begin{array}{l}\text { If edits } \\
\text { pass } \\
\text { Active } \\
\text { If edits fail } \\
\text { Null }\end{array}$ \\
\hline $\begin{array}{l}\text { Display } \\
\text { login info } \\
\text { online }\end{array}$ & $\begin{array}{l}\text { Active or } \\
\text { Inactive }\end{array}$ & $\begin{array}{l}\text { Accesses } \\
\text { NWDB } \\
\text { screen }\end{array}$ & $n / a$ & $\begin{array}{l}\text { Accesses } \\
\text { NWDB } \\
\text { screen }\end{array}$ & $\begin{array}{l}\text { Accesses } \\
\text { NWDB } \\
\text { screen }\end{array}$ & $\begin{array}{l}\text { Access- } \\
\text { es } \\
\text { NWDB } \\
\text { screen }\end{array}$ & $\begin{array}{l}\text { Accesses } \\
\text { NWDB } \\
\text { screen }\end{array}$ & $\begin{array}{l}\text { Accesses } \\
\text { all related } \\
\text { tables to get } \\
\text { login info }\end{array}$ & Reads login & $\begin{array}{l}\text { Active or } \\
\text { Inactive }\end{array}$ \\
\hline $\begin{array}{l}\text { Update } \\
\text { login name }\end{array}$ & Active & $\begin{array}{l}\text { May place } \\
\text { phone call } \\
\text { to NWDB } \\
\text { Admin or } \\
\text { Password } \\
\text { Control; } \\
\text { Completes } \\
\text { form }\end{array}$ & n/a & $\begin{array}{l}\text { May } \\
\text { receive } \\
\text { phone call } \\
\text { from Line } \\
\text { Org } \\
\text { Individual; } \\
\text { Receives } \\
\text { Discrepancy } \\
\text { Report; } \\
\text { Updates } \\
\text { login }\end{array}$ & \begin{tabular}{|l} 
May \\
receive \\
phone call \\
from Line \\
Org \\
Individual; \\
Receives \\
Discrepancy \\
Report; \\
Updates \\
login
\end{tabular} & $n / a$ & $n / a$ & $\begin{array}{l}\text { Enforces } \\
\text { edits; } \\
\text { Changes } \\
\text { login info }\end{array}$ & $\begin{array}{l}\text { Reads login } \\
\text { Updates } \\
\text { login }\end{array}$ & Active \\
\hline \begin{tabular}{|l|} 
Update \\
account \\
expiration \\
date for \\
each \\
classification \\
level
\end{tabular} & Active & $n / a$ & $n / a$ & $n / a$ & \begin{tabular}{|l} 
Reads \\
report; \\
Uses \\
account \\
screen to \\
reauthorize \\
account \\
expiration \\
date
\end{tabular} & $n / a$ & $n / a$ & $\begin{array}{l}\text { Enforces } \\
\text { edits; Sets } \\
\text { expiration } \\
\text { date ahead } \\
\text { either } 6 \\
\text { months or } 1 \\
\text { year, } \\
\text { according to } \\
\text { classification } \\
\text { level }\end{array}$ & $\begin{array}{l}\text { Reads login } \\
\text { Updates } \\
\text { login }\end{array}$ & Active \\
\hline
\end{tabular}


Table 7 Logins Process/Actor State Transition Matrix (Valid Status List: Null, Active, Inactive) (Continued)

\begin{tabular}{|c|c|c|c|c|c|c|c|c|c|c|}
\hline $\begin{array}{c}\text { Object Life } \\
\text { Cycle } \\
\text { Event } \\
\text { (Task) }\end{array}$ & $\operatorname{Beginning}_{\text {State }}$ & & & etlons Taken- & -By Busines & is Functi & & & $\begin{array}{l}\text { Elementary } \\
\text { Processes }\end{array}$ & $\begin{array}{c}\text { Ending } \\
\text { State }\end{array}$ \\
\hline & $\begin{array}{c}\text { Incoming } \\
\text { Status }\end{array}$ & $\begin{array}{l}\text { Line Org } \\
\text { Individual }\end{array}$ & HRIS & $\begin{array}{l}\text { NWDB } \\
\text { Admin }\end{array}$ & $\begin{array}{l}\text { Password } \\
\text { Admin }\end{array}$ & $\begin{array}{l}\text { LAN } \\
\text { POC }\end{array}$ & $\begin{array}{l}\text { Security } \\
\text { System }\end{array}$ & $\begin{array}{c}\text { NWDB } \\
\text { Application } \\
\text { Program }\end{array}$ & & $\begin{array}{c}\text { Resulting } \\
\text { Status }\end{array}$ \\
\hline $\begin{array}{l}\text { Report } \\
\text { customers } \\
\text { with expired } \\
\text { logins }\end{array}$ & Active & $n / a$ & $n / a$ & $\begin{array}{l}\text { Reads } \\
\text { report }\end{array}$ & \begin{tabular}{|l|} 
Reads \\
report
\end{tabular} & $n / a$ & $n / a$ & \begin{tabular}{|l|} 
Generates \\
report of \\
account \\
expiration \\
dates less \\
than today's \\
date
\end{tabular} & Reads login & Active \\
\hline $\begin{array}{l}\text { Report } \\
\text { customers } \\
\text { with Inactive } \\
\text { login status } \\
\text { greater } \\
\text { than1 year }\end{array}$ & Inactive & $n / a$ & $n / a$ & $\begin{array}{l}\text { Reads } \\
\text { report }\end{array}$ & \begin{tabular}{|l} 
Reads \\
report
\end{tabular} & n/a & $n / a$ & \begin{tabular}{|l|} 
Generates \\
report of \\
logins \\
whose login \\
status has \\
been \\
inactive \\
greater than \\
1 year
\end{tabular} & Reads login & Inactive \\
\hline $\begin{array}{l}\text { Deactivate } \\
\text { login }\end{array}$ & Active & $n / a$ & $n / a$ & \begin{tabular}{|l|} 
Reads \\
Discrepancy \\
Report; \\
Updates \\
login
\end{tabular} & \begin{tabular}{|l|} 
Reads \\
Discrepancy \\
Report; \\
Updates \\
login
\end{tabular} & n/a & $n / a$ & \begin{tabular}{|l|} 
Enforces \\
edits; \\
Records \\
update in \\
login info
\end{tabular} & $\begin{array}{l}\text { Reads login } \\
\text { Updates } \\
\text { login }\end{array}$ & Inactive \\
\hline Delete login & Inactive & $n / a$ & $n / a$ & \begin{tabular}{|l} 
Reads \\
report of \\
deleted \\
logins
\end{tabular} & \begin{tabular}{|l|} 
Reads \\
report of \\
deleted \\
logins
\end{tabular} & $n / a$ & $n / a$ & \begin{tabular}{|l|} 
Deletes \\
login that \\
has been \\
inactive \\
more than 1 \\
year
\end{tabular} & \begin{tabular}{|l|} 
Deletes \\
login
\end{tabular} & Null \\
\hline $\begin{array}{l}\text { Create login } \\
\text { from online } \\
\text { screen (only } \\
\text { for } \\
\text { contractors } \\
\text { \& visitors }\end{array}$ & & Outside th & project & & & & & & & \\
\hline $\begin{array}{l}\text { Reauthorize } \\
\text { account } \\
\text { explration } \\
\text { date from } \\
\text { online } \\
\text { screen (only } \\
\text { for } \\
\text { contractors } \\
\text { \& visitors) }\end{array}$ & & Outside the & project's s & & & & & & & \\
\hline
\end{tabular}


Table 8 Accounts Process/Actor State Transition Matrix (Central service/LAN POC accounts)

(Valid Status List: Null, Active, Inactive)

\begin{tabular}{|c|c|c|c|c|c|c|c|c|c|c|}
\hline \multirow[t]{2}{*}{$\begin{array}{c}\text { Object Llife } \\
\text { Cycle } \\
\text { Event } \\
\text { (Task) }\end{array}$} & \multirow{2}{*}{\begin{tabular}{|c|}
$\begin{array}{c}\text { Beginning } \\
\text { State }\end{array}$ \\
$\begin{array}{c}\text { Incoming } \\
\text { Status }\end{array}$ \\
\end{tabular}} & \multicolumn{7}{|c|}{ Actions Taken-By Business Function } & \multirow[t]{2}{*}{$\begin{array}{l}\text { Elementary } \\
\text { Processes }\end{array}$} & \multirow{2}{*}{\begin{tabular}{|c|}
$\begin{array}{c}\text { Ending } \\
\text { State }\end{array}$ \\
$\begin{array}{c}\text { Resulting } \\
\text { Status }\end{array}$
\end{tabular}} \\
\hline & & $\begin{array}{l}\text { Line Org } \\
\text { Individual }\end{array}$ & HRIS & $\begin{array}{l}\text { NWDB } \\
\text { Admin }\end{array}$ & $\begin{array}{l}\text { Password } \\
\text { Admin }\end{array}$ & LAN POC] & $\begin{array}{l}\text { Security } \\
\text { System }\end{array}$ & $\begin{array}{c}\text { NWDB } \\
\text { Application } \\
\text { Program }\end{array}$ & & \\
\hline \begin{tabular}{|l|} 
Assign \\
customer \\
an account \\
for each \\
desired \\
central \\
service
\end{tabular} & Nuil & $\begin{array}{l}\text { Submits } \\
\text { request } \\
\text { form for } \\
\text { confidential } \\
\text { and secret }\end{array}$ & $n / a$ & $\begin{array}{l}\text { Assigns } \\
\text { account }\end{array}$ & $\begin{array}{l}\text { Assigns } \\
\text { account }\end{array}$ & \begin{tabular}{|l|} 
Assigns \\
account \\
(LAN \\
POC \\
accounts \\
only)
\end{tabular} & $n / a$ & $\begin{array}{l}\text { Enforces } \\
\text { edits } \\
\text { (validates } \\
\text { case } \\
\text { number \& } \\
\text { clearance } \\
\text { level) }\end{array}$ & $\begin{array}{l}\text { Reads } \\
\text { account } \\
\text { Creates } \\
\text { account }\end{array}$ & \begin{tabular}{|l|} 
If edits \\
pass \\
Active \\
If edits fail \\
Null
\end{tabular} \\
\hline \begin{tabular}{|l|} 
Set up \\
accounts for \\
service \\
group
\end{tabular} & Null & $\begin{array}{l}\text { Submits } \\
\text { request for } \\
\text { service } \\
\text { group } \\
\text { under RSN } \\
\text { or SSN }\end{array}$ & $n / a$ & $\begin{array}{l}\text { Reads } \\
\text { request; } \\
\text { Accesses } \\
\text { account } \\
\text { screen }\end{array}$ & $\begin{array}{l}\text { Reads } \\
\text { request; } \\
\text { Accesses } \\
\text { account } \\
\text { screen }\end{array}$ & $n / a$ & $n / a$ & \begin{tabular}{|l|} 
Enforces \\
edits; \\
Creates \\
accounts for \\
service \\
groups
\end{tabular} & $\begin{array}{l}\text { Create } \\
\text { account }\end{array}$ & \begin{tabular}{|l|} 
If edits \\
pass \\
Active \\
If edits fail \\
Null
\end{tabular} \\
\hline \begin{tabular}{|l} 
Display \\
account \\
info online
\end{tabular} & $\begin{array}{l}\text { Active or } \\
\text { Inactive }\end{array}$ & $\begin{array}{l}\text { Accesses } \\
\text { NWDB } \\
\text { screen }\end{array}$ & $n / a$ & $\begin{array}{l}\text { Accesses } \\
\text { NWDB } \\
\text { screen }\end{array}$ & $\begin{array}{l}\text { Accesses } \\
\text { NWDB } \\
\text { screen }\end{array}$ & \begin{tabular}{|l|} 
Accesses \\
NWDB \\
screen
\end{tabular} & $\begin{array}{l}\text { Accesses } \\
\text { NWDB } \\
\text { screen }\end{array}$ & \begin{tabular}{|l|} 
Accesses \\
all related \\
tables to get \\
login info
\end{tabular} & Reads login & $\begin{array}{l}\text { Active or } \\
\text { Inactive }\end{array}$ \\
\hline \begin{tabular}{|l|} 
Reauthorize \\
account
\end{tabular} & Active & This task is $r$ & reported or & the login entity & & & & & $\begin{array}{l}\text { Updates } \\
\text { account }\end{array}$ & Active \\
\hline \begin{tabular}{|l|} 
Report \\
customers \\
with \\
account \\
expiration \\
dates less \\
than \\
today's date
\end{tabular} & Active & n/a & $n / a$ & Reads report & $\begin{array}{l}\text { Reads } \\
\text { report }\end{array}$ & $n / a$ & $n / a$ & \begin{tabular}{|l|} 
Generates \\
report of \\
account \\
expiration \\
dates less \\
than today's \\
date
\end{tabular} & $\begin{array}{l}\text { Reads } \\
\text { account }\end{array}$ & Active \\
\hline \begin{tabular}{|l|} 
Report \\
customers \\
withinactive \\
account \\
status \\
greater \\
than1 year
\end{tabular} & Inactive & $n / a$ & n/a & Reads report & $\begin{array}{l}\text { Reads } \\
\text { report }\end{array}$ & $n / a$ & nn/a & \begin{tabular}{|l|} 
Generates \\
report of \\
accounts \\
whose \\
account \\
status has \\
been \\
inactive \\
greater than \\
1 year
\end{tabular} & $\begin{array}{l}\text { Reads } \\
\text { account }\end{array}$ & Inactive \\
\hline $\begin{array}{l}\text { Deactivate } \\
\text { account }\end{array}$ & Active & $\begin{array}{l}\text { Submits } \\
\text { request to } \\
\text { deactivate } \\
\text { account }\end{array}$ & $n / a$ & $n / a$ & $\begin{array}{l}\text { Reads } \\
\text { requests; } \\
\text { Updates } \\
\text { account }\end{array}$ & $\begin{array}{l}\text { Reads } \\
\text { requests; } \\
\text { Updates } \\
\text { account } \\
\text { (LAN } \\
\text { POC } \\
\text { accounts } \\
\text { only) }\end{array}$ & $n / a$ & $\begin{array}{l}\text { Enforces } \\
\text { edits; } \\
\text { Records } \\
\text { update in } \\
\text { account info }\end{array}$ & $\begin{array}{l}\text { Reads } \\
\text { account } \\
\text { Updates } \\
\text { account }\end{array}$ & Inactive \\
\hline
\end{tabular}


Table 8 Accounts Process/Actor State Transition Matrix (Central service/LAN POC accounts)

(Valid Status List: Null, Active, Inactive) (Continued)

\begin{tabular}{|c|c|c|c|c|c|c|c|c|c|c|}
\hline \multirow[t]{2}{*}{$\begin{array}{c}\text { Object Liffe } \\
\text { Cycle } \\
\text { Event } \\
\text { (Task) }\end{array}$} & \multirow{2}{*}{\begin{tabular}{|c} 
Beginning \\
State
\end{tabular}} & \multicolumn{7}{|c|}{ Actions Taken-By Business Function } & \multirow[t]{2}{*}{$\begin{array}{l}\text { Elementary } \\
\text { Processes }\end{array}$} & \multirow{2}{*}{\begin{tabular}{|c}
$\begin{array}{c}\text { Ending } \\
\text { State }\end{array}$ \\
$\begin{array}{c}\text { Resulting } \\
\text { Status }\end{array}$
\end{tabular}} \\
\hline & & $\begin{array}{l}\text { Line Org } \\
\text { Indlvidual }\end{array}$ & HRIS & $\begin{array}{l}\text { NWDB } \\
\text { Admin }\end{array}$ & $\begin{array}{c}\text { Password } \\
\text { Admin }\end{array}$ & LAN POC & $\begin{array}{l}\text { Security } \\
\text { System }\end{array}$ & $\begin{array}{c}\text { NWDB } \\
\text { Application } \\
\text { Program }\end{array}$ & & \\
\hline $\begin{array}{l}\text { Deactivate } \\
\text { account } \\
\text { through } \\
\text { HRIS }\end{array}$ & Active & $n / a$ & \begin{tabular}{|l|} 
Sends \\
batch \\
upload \\
file \\
(Changes \\
file 5 \\
nights a \\
week; Big \\
file every \\
Friday)
\end{tabular} & $n / a$ & $n / a$ & $n / a$ & $n / a$ & \begin{tabular}{|l|} 
Enforces \\
edits; \\
Records \\
update in \\
account info
\end{tabular} & $\begin{array}{l}\text { Reads } \\
\text { account } \\
\text { Updates } \\
\text { account }\end{array}$ & Inactive \\
\hline $\begin{array}{l}\text { Delete } \\
\text { account }\end{array}$ & Inactive & $n / a$ & $n / a$ & $\begin{array}{l}\text { Reads report } \\
\text { of inactive } \\
\text { accounts }\end{array}$ & $\begin{array}{l}\text { Reads } \\
\text { report of } \\
\text { inactive } \\
\text { accounts }\end{array}$ & n/a & n/a & \begin{tabular}{|l|} 
Deletes \\
account that \\
has been \\
inactive \\
more than 1 \\
year
\end{tabular} & $\begin{array}{l}\text { Deletes } \\
\text { account }\end{array}$ & Null \\
\hline \begin{tabular}{|l|} 
Create \\
account \\
from online \\
screen (only \\
for \\
contractors \\
\& visitors
\end{tabular} & & \multicolumn{7}{|c|}{ Outside the project's scope } & & \\
\hline \begin{tabular}{|l|} 
Reauthorize \\
account \\
expiration \\
date from \\
online \\
screen (only \\
for \\
contractors \\
\& visitors)
\end{tabular} & & \multicolumn{7}{|c|}{ Outside the project's scope \& reported on login entity } & & \\
\hline
\end{tabular}




\section{Storyboard Diagrams}

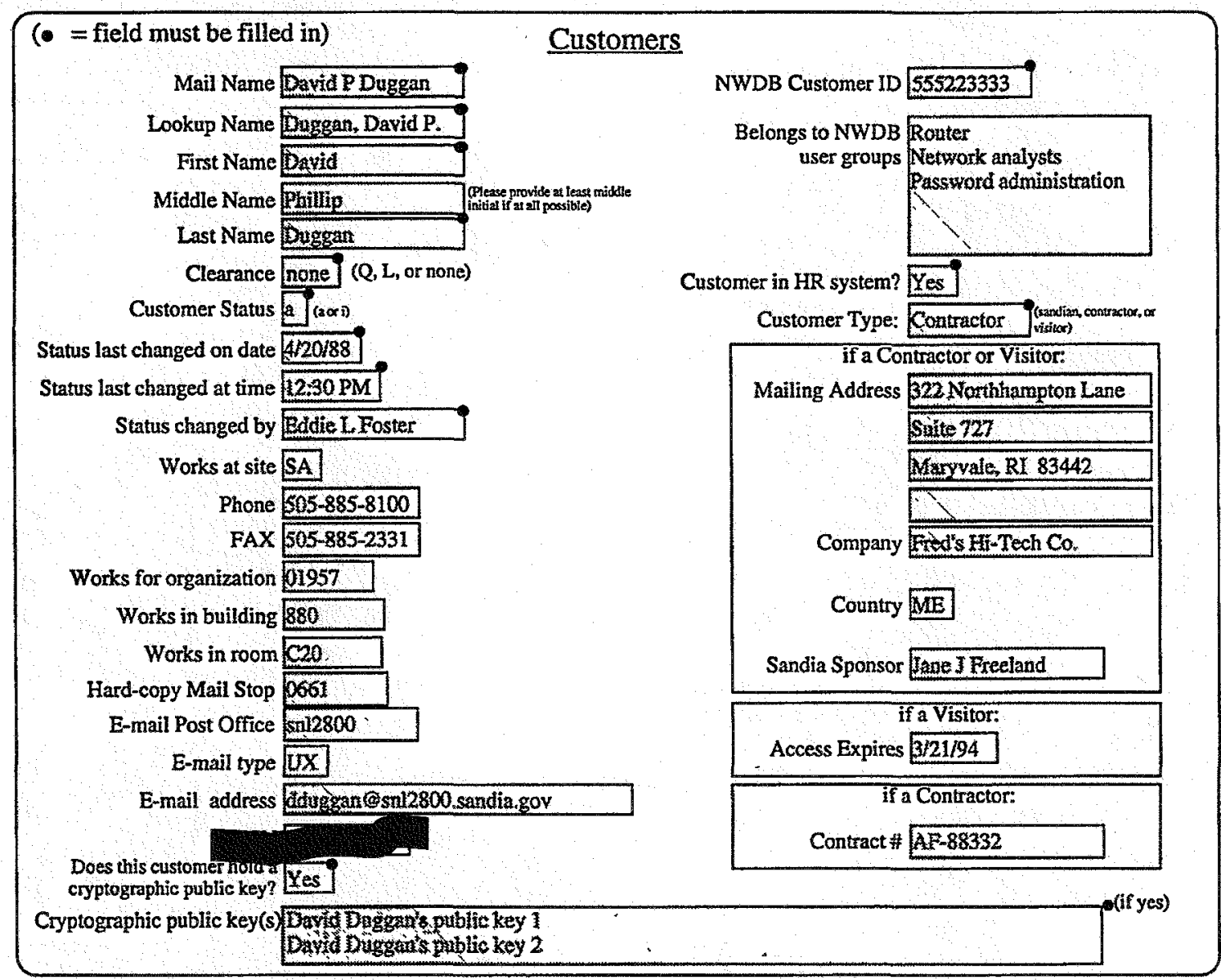




\section{CRUD Matrix}

\section{Deliverable 7}

The CRUD (Create, Read, Update, Delete) matrix identifies each elementary process used on each core object of the information system. Accompanying analysis assists in verifying that each object is supported by a create, read, update, and delete process-it also helps identify redundancy of processes for an object.

This approach clusters elementary processes with objects, revealing a matrix in process sequence and identifying clusters from top left to bottom right.

In most instances, the C's for Create will fall on the diagonal. All other uses appear in the lower triangle of the matrix. The software engineer determines the cluster boundaries. The resulting rectangle will show the related process and objects that should be in a common module or grouping of objects and activities.

Some CASE tools will perform initial clustering on a matrix, but human interaction is usually required by the software engineer to finalize these groupings.

Note: In the following example, words in italics indicate the groupings that form logical screen processes. The $\mathbf{R}$ indicates mandatory read information, while $\mathbf{r}$ represents read to find optional information. 


\section{CRUD Matrix}

Table 9 CRUD Matrix-Create Version Only

\begin{tabular}{|c|c|c|c|c|c|c|c|c|c|c|c|c|c|c|}
\hline $\begin{array}{l}\text { Object creation dependency matrix } \\
\text { (The C in CRUD) }\end{array}$ & 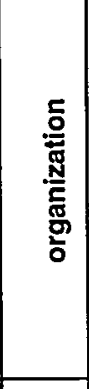 & 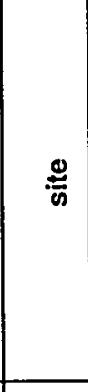 & 岁 & 蒿 & $\frac{0}{\stackrel{D}{D}}$ & 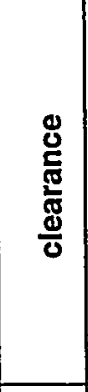 & 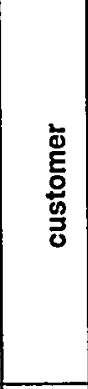 & 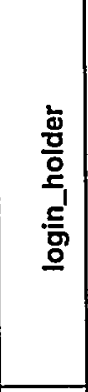 & 등 & 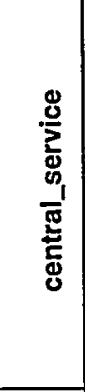 & $\begin{array}{l}\text { 를 } \\
\text { 옹 } \\
\text { ్․ }\end{array}$ & 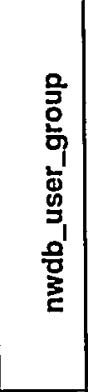 & 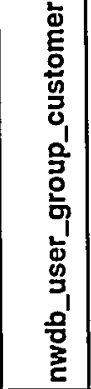 & 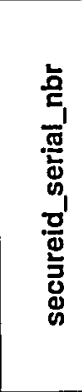 \\
\hline create organization & $c$ & & & & & & & & & & & & & \\
\hline create site & & C & & & & & & & & & & & & \\
\hline create case & & & C & & & & & & & & & & & \\
\hline create agent & & & & C & & & & & & & & & & \\
\hline create status & & & & & C & & & & & & & & & \\
\hline create clearance & & & & & & c & cust & & & & & & & \\
\hline create customer & $r$ & $r$ & & $R$ & $R$ & $R$ & $\mathrm{c}$ & & login & & & & $g r p$ & \\
\hline create login_holder & & & & & & & $\mathbf{R}$ & $c$ & & & & & & \\
\hline create login & & & & $\mathrm{R}$ & R & & & $R$ & C & & acct & & & \\
\hline create central_service & & & & & & & & & & C & & & & \\
\hline create account & & & $r$ & $\mathbf{R}$ & $R$ & & $r$ & & $R$ & $R$ & C & & & \\
\hline create nwdb_user_group & $r$ & & & & & & & & & & & C & & \\
\hline create nwdb_user_group_customer & & & & & & & $R$ & & & & & $R$ & C & \\
\hline create securid_serial_nbr & & & & & & & & & & & $\mathbf{r}$ & & & c \\
\hline
\end{tabular}




\section{Extended Presentation Sets}

\section{Deliverable 8}

Extended Presentation Sets consist of storyboard diagrams that include vendor-specific and implementation-specific features, as well as application of standard template features for the enterprise systems. These are normally "extended" or evolved from initial diagrams in Deliverable 6 (see "Storyboard Diagrams" on page A-34). They are often produced and managed electronically. An evolutionary prototype might begin with diagrams and electronic screens produced by the presentation layer tool. As these designs evolve, test data and coding are added for rapid production of the first product.

This example extracts specific information from the NWDB. To view the complete deliverable for this subset of the NWDB, see the World Wide Web:

http:// sass902d.itd.sandia.gov/SILCExam.pdf 


\title{
Extended Presentation Sets
}

\author{
Customer List Screen
}

Figure 6 Customer List Screen

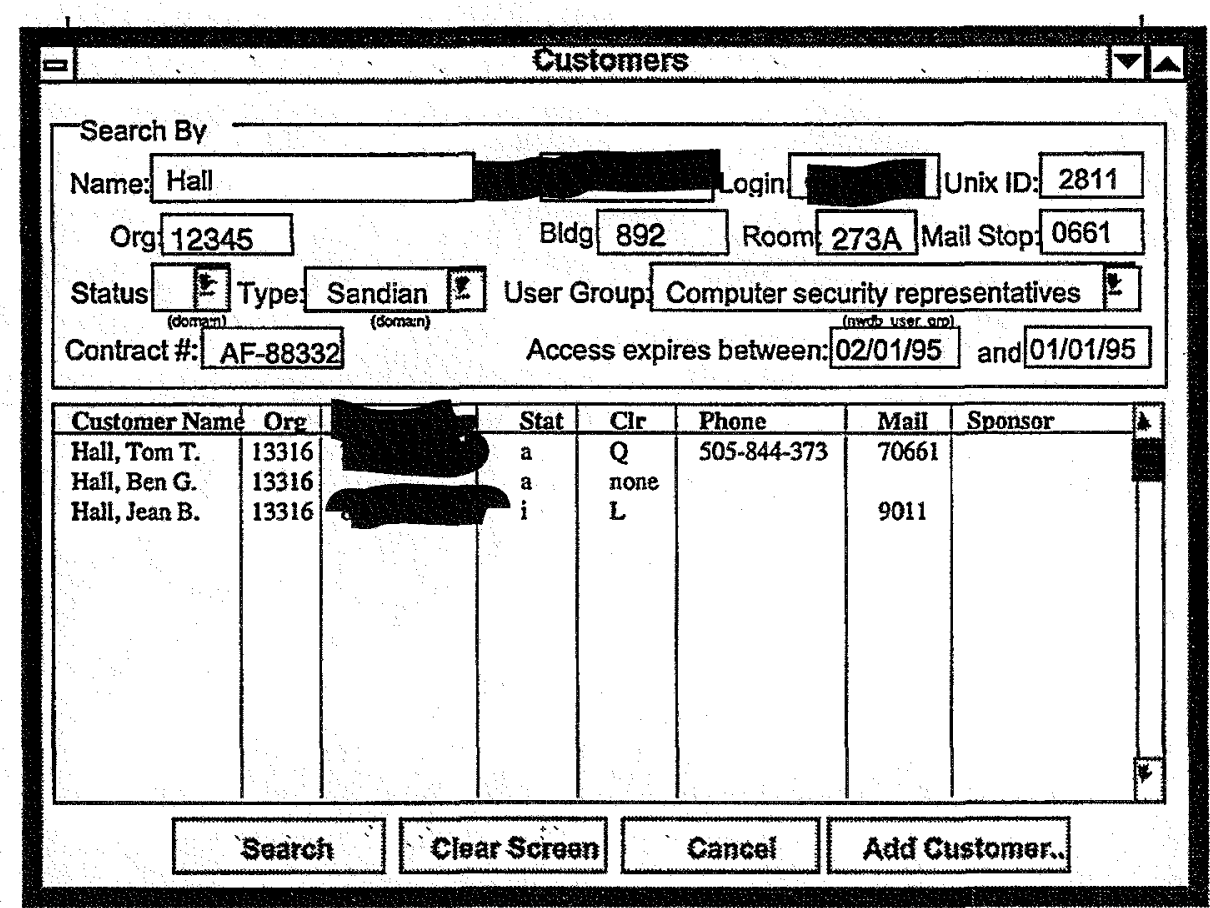

Records used

contract

customer

login

nwdb user_grp_mbr

\section{Access controls}

clist-10 A user must belong to one of the NWDB user groups "Password

administration" or "NWDB administrators" to click the Add button on this screen.

\section{Details}

clist-20 Login name, or Unix User ID is entered, all other data should be ignored and a match made directly on that field. Otherwise, search for all matches. Entering any one of Login name, or Unix User ID will blank out the other three.

clist-30 Matches should be obtainable based on partial login name, lookup name or org. (Other matches should be by full field content.) 
Say in Help what fields can be partially entered. Also remind them to place leading zeroes on org if want " $013 \times x$ " rather than " $13 \mathrm{xxx."}$

clist-50 When a building is input, the input field should be altered to strip any leading " $\mathrm{B}$ " and any embedded spaces, blanks, "-," or "\%," and should show on the screen in stripped form. Only a-Z, A-Z, and 0-9 may be input, and these will be forced to upper case.

clist- 60 When a room is input, the input field should be altered to strip any embedded spaces, blanks, "-", or " $"$ ", and should show on the screen in stripped form. Only a-z, $A-Z$, and 0-9 may be input, and these will be forced to upper case. 


\section{Customer Detail Screen}

Figure 7 Customer Screens

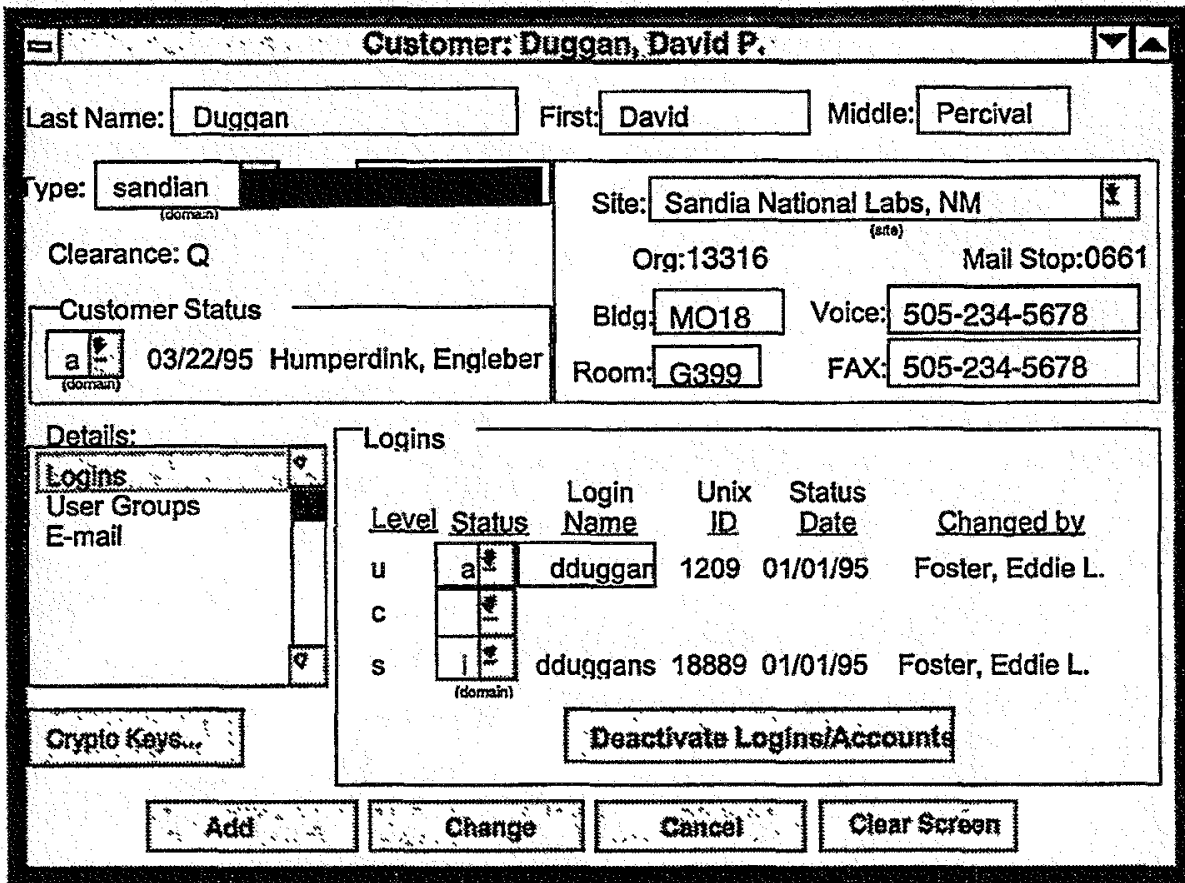

\begin{tabular}{|c|c|}
\hline Available user groups & User groups for this customer \\
\hline 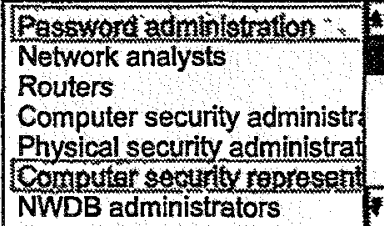 & $\begin{array}{l}\text { Password administration } \\
\text { NWDB administrators } \\
\text { E-mail support }\end{array}$ \\
\hline Add> & * Remove All \\
\hline
\end{tabular}

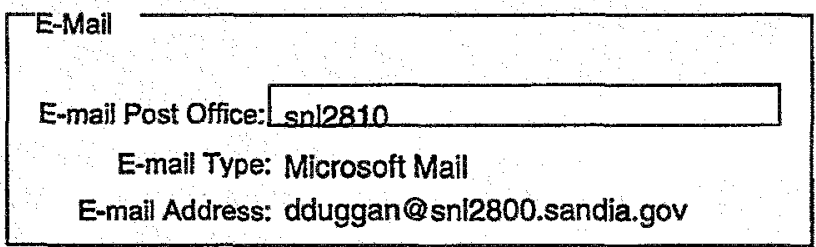

\section{Records used}

accounts (update)

customer (update)

emailpo

login (update)

nwdb_user_grp

nwdb user_grp_mbr (update) 
reference_record (update)

site

\section{Access controls}

cust-10 A user must belong to one of the NWDB user groups "Password administration" or "NWDB administrators" to update any data on this screen.

\section{Details}

cust-20 When a customer is added for the first time (when "Add" is clicked), a new customer $\mathbb{D}$ must be generated (this is the primary key to customer). Do the generation as follows: get the last customer ID used from the reference record and add 1. Set the last customer ID used to that value, and set the customer ID to that value.

cust-40 Last, first, and middle name fields should be only alphabetic plus any embedded "-" or blank spaces, and the first character of the name should be forced to be upper case, and the first character after any "-" or blank should be forced to be upper case.

cust-50 If the customer first, middle, or last name is changed, the following should happen: The customer's first name, a space, the first character of the middle name and a space (if there is a middle name), and last name should be concatenated to form the customer mail name. The customer's last name, a comma, a space, first name, and if there is a middle name, another space, the first character of the middle name and a period should be concatenated to form the customer lookup name. Customer lookup name and mail name do not show on the screen.

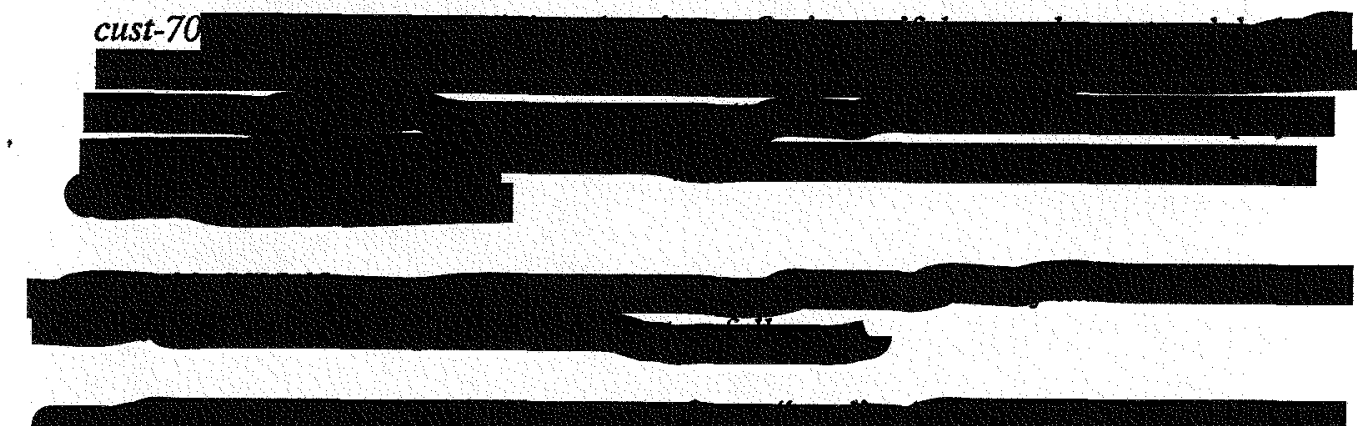

the record.

cust-100 Clearance code should be automatically defaulted to "none" if a customer is initially added on this screen. Clearance code cannot be entered on-line. Clearance code is updated only from the HR system.

If the customer status is changed to " $a$," or first entered as " $a$," a Login Name and User ID may need to be automatically generated (this is detailed below).

The field shown for "Site" should be the site description, even though that is not the primary key.

cust-120 Site is required for customers of type "sandian", even though it is nullable in the record. 
Note that a customer's org. may not be entered here-it is updated only from the HR system.

Note that mail stop may not be entered here-it is updated only from the HR system.

cust- 150 When a building is input, any leading " $\mathrm{B}$ " and any embedded spaces, blanks, "-", or " "P" should be stripped out and the building number displayed in stripped form.

Only a-z, A-Z, and 0-9 may be input, and these will be forced to upper case.

cust-151** The building number that a customer works in should exist in the liscopy "building" table, in attribute building.bldgnum.

cust-160 When a room is input, any embedded spaces, blanks, “-", or "/" should be stripped out and the room number displayed in stripped form. Only a-z, A-Z, and 0-9 may be input, and these will be forced to upper case.

Phone numbers may be entered on-line for phones in other countries, so there is no set format for phone number. Phone number should be stored without any embedded dashes or spaces, so these should be stripped on input.

cust-170 For display, any phone numbers made of 10 characters should have parens and a dash inserted as they are typed and be shown in the format (999) 999-9999.

Phone numbers with more or less than 10 characters should display just as a number.

(Note that the HR update will keep most phone numbers current.)

(Note: The Logins detail is listed last in this section, even though it is the default first detail, since it is the most complicated and you might want to save it for last). 


\section{Central Services List Screen}

Figure 8 Central Services Screen

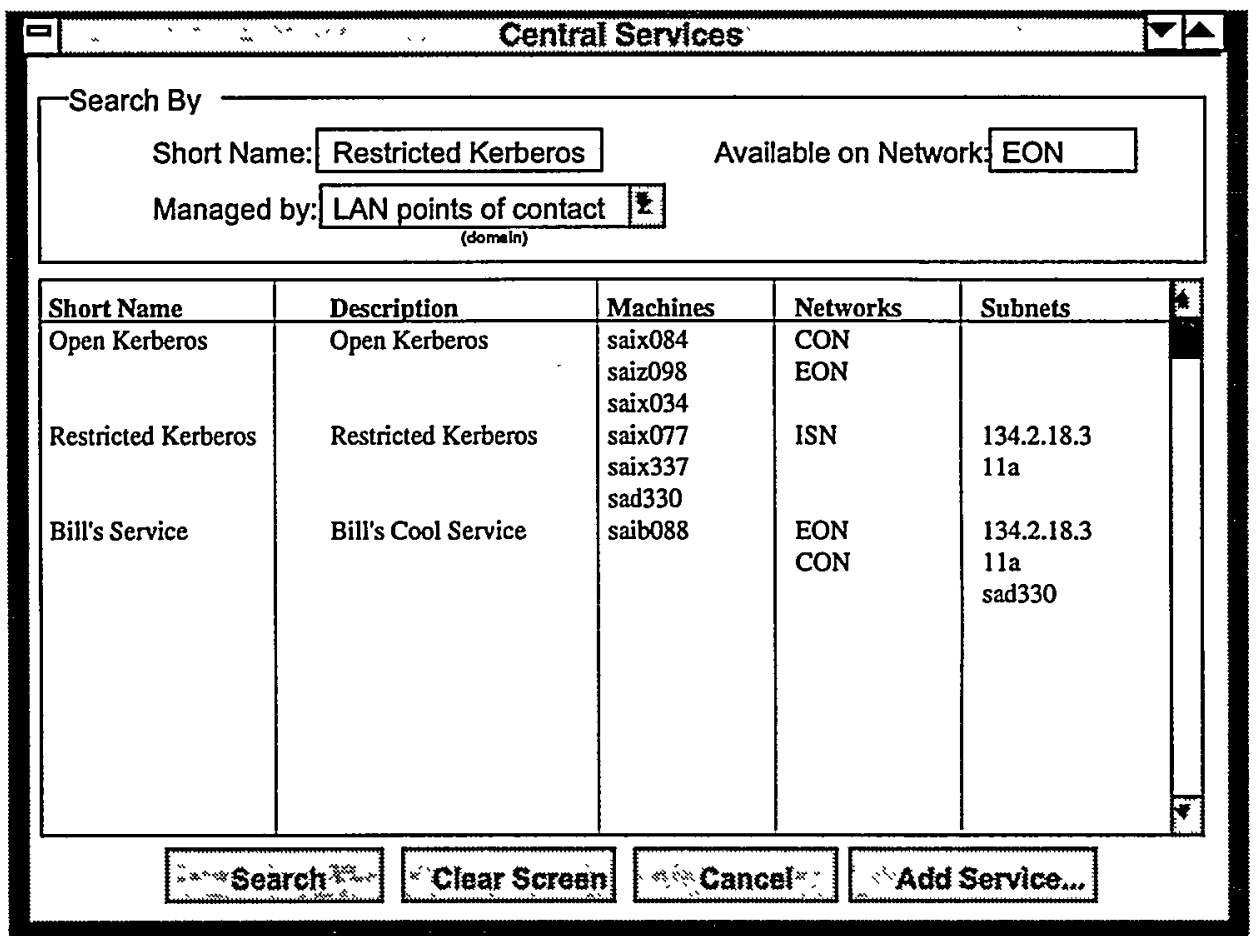

\section{Records used}

central_svc

central_svc_machine

central_svc_network

central_svc_subnet

\section{Access controls}

cslist-10 A user must belong to the user group "NWDB administrators" or "Password administration" to click the Add button on this screen.

\section{Details}

(none) 


\section{Central Service Detail Screen}

Figure 9 Central Service Detail Screen

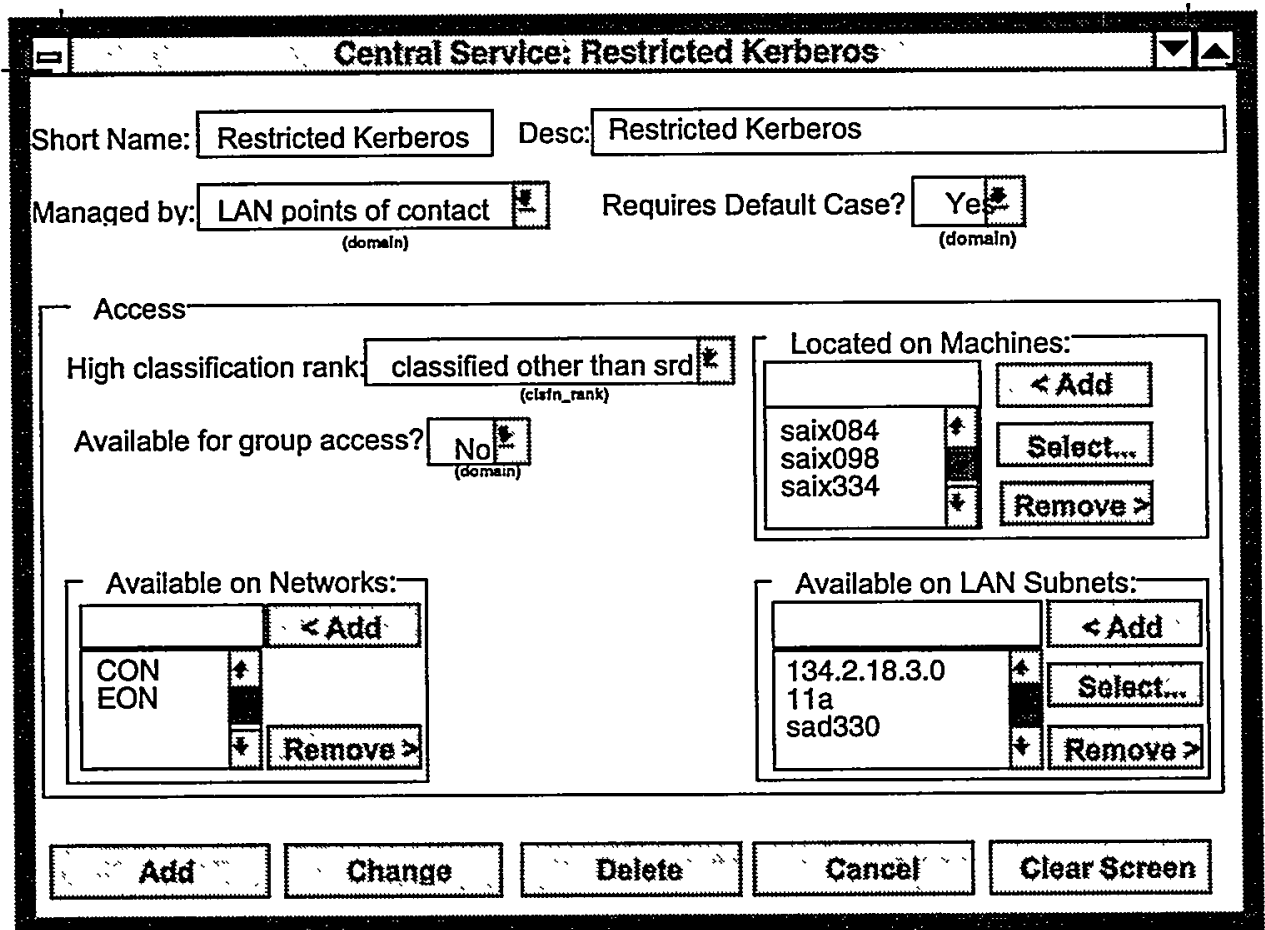

Records used

central_svc (updated)

central_svc_machine (updated)

machine

clsfn_rank

lan_subnet

central_svc_subnet (updated)

network

central_svc_network (updated)

\section{Access controls}

cs-10 A user must belong to the user group "NWDB administrators" or "Password administration" to update any data on this screen.

\section{Details}

Note: The pick-list for clsfn_rank is not the primary key field. For all display purposes (here and elsewhere), we are using the description of the classification rank, not its numeric code. Users other than NWDB administrators should never see the numeric code.

cs-20 A central service may only be managed by the NWDB User groups "LAN points of contact" and "Password administration," so rather than having a pick_list into the nwdb_user_grp table, we suggest a short custom picklist with these two values. 
Note: The two flags "Requires default case?" and "Available for group access?" are shown as "Yes" and "No," but these values are stored in the database as "Y" and "N."

$c s$-30 A central service is a POC-managed central service when it is managed by the NWDB User group "LAN points of contact." Only a POC-managed central service may be available on a subnet-hide this box otherwise.

\section{Accounts List Screen}

Figure 10 Accounts Screen

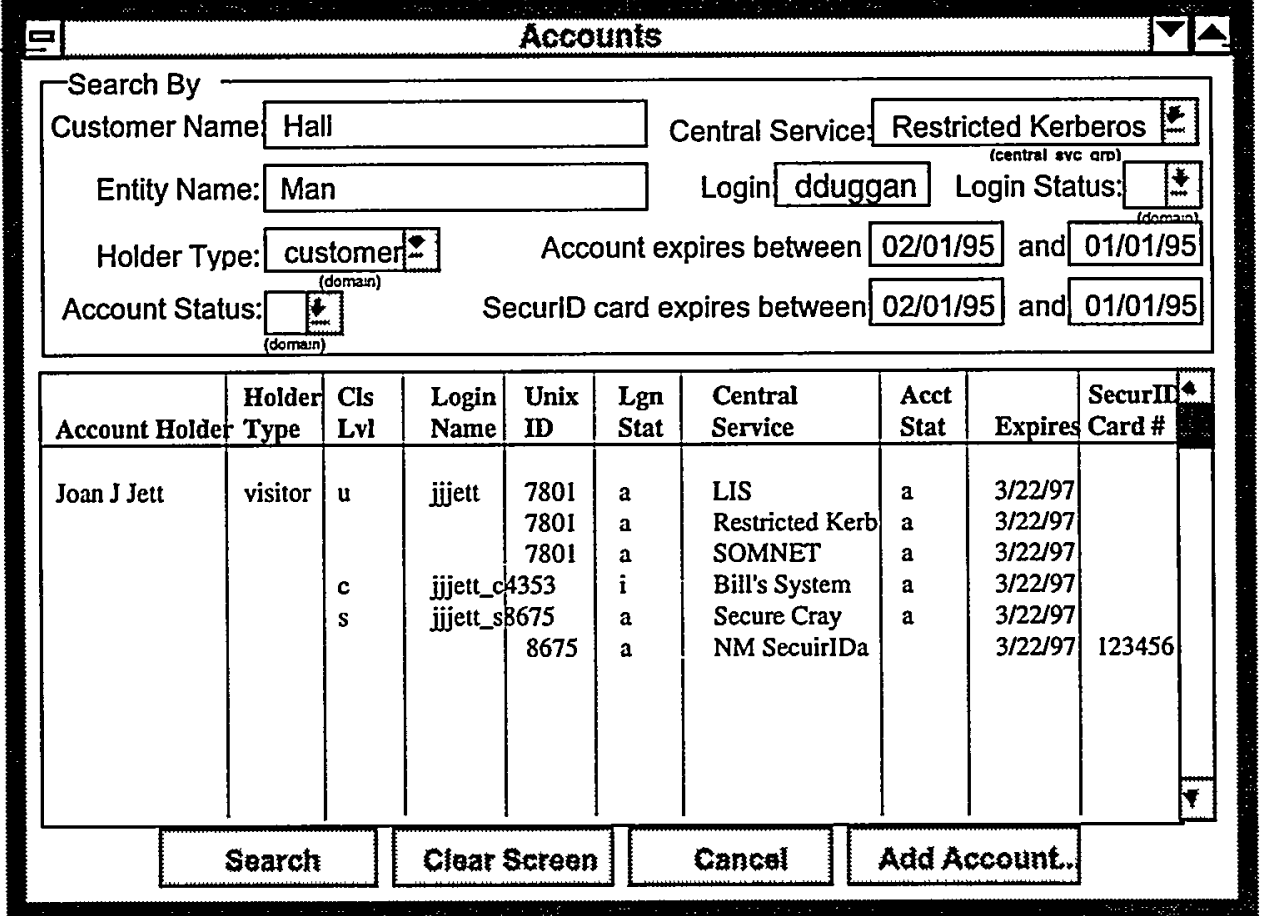

\section{Records used}

customer

entity

login

account

central_svc

\section{Access controls}

alist-10 A user must belong to the user group "NWDB administrators," "Password administration," or "LAN points of contact" to click the Add button on this screen.

\section{Details}

alist-20 Login name when entered must be alpha and lower case.

alist-30 If the search criteria yields a customer or entity without a Login Name, or with a Login Name but without any accounts, go ahead and show them (i.e., show all 
matches, even if you can't fill out the whole report line). If the search criteria yields both customers and entities, show both in the report.

alist-40 "Account holder type" is a combination of login holder type (customer, entity) and customer type. Basically, we want to convert login holder type "customer" into the three types of customers for display on this query.

alist-50 Each login name for a login holder should show only once, even if there are multiple accounts for that login name.

Note that the fields "Account Holder" and "Central Service" in the list are truncated to make room. 


\section{DB Schema}

\section{Deliverable 9}

The Physical Database, using the constructs of the vendor software and the additional information needed by the implementer of the system, is documented with the database schema diagram in the form of IDEF1X. Optionally, the SQL listings may be used. The SQL to support all of the elementary processes for CRUD (Create, Read, Update, and Delete) may be automatically generated from the physical model by a tool.

To view the complete SQL listings for this subset of the NWDB, see the World Wide Web:

http:// sass902d.itd.sandia.gov/SILCExam.pdf

Note: Keys are listed first in each table with a line following the last item in the key. Data items which uniquely identify an object are usually the primary key. The following describes the symbols used in an IDEF1X diagram.

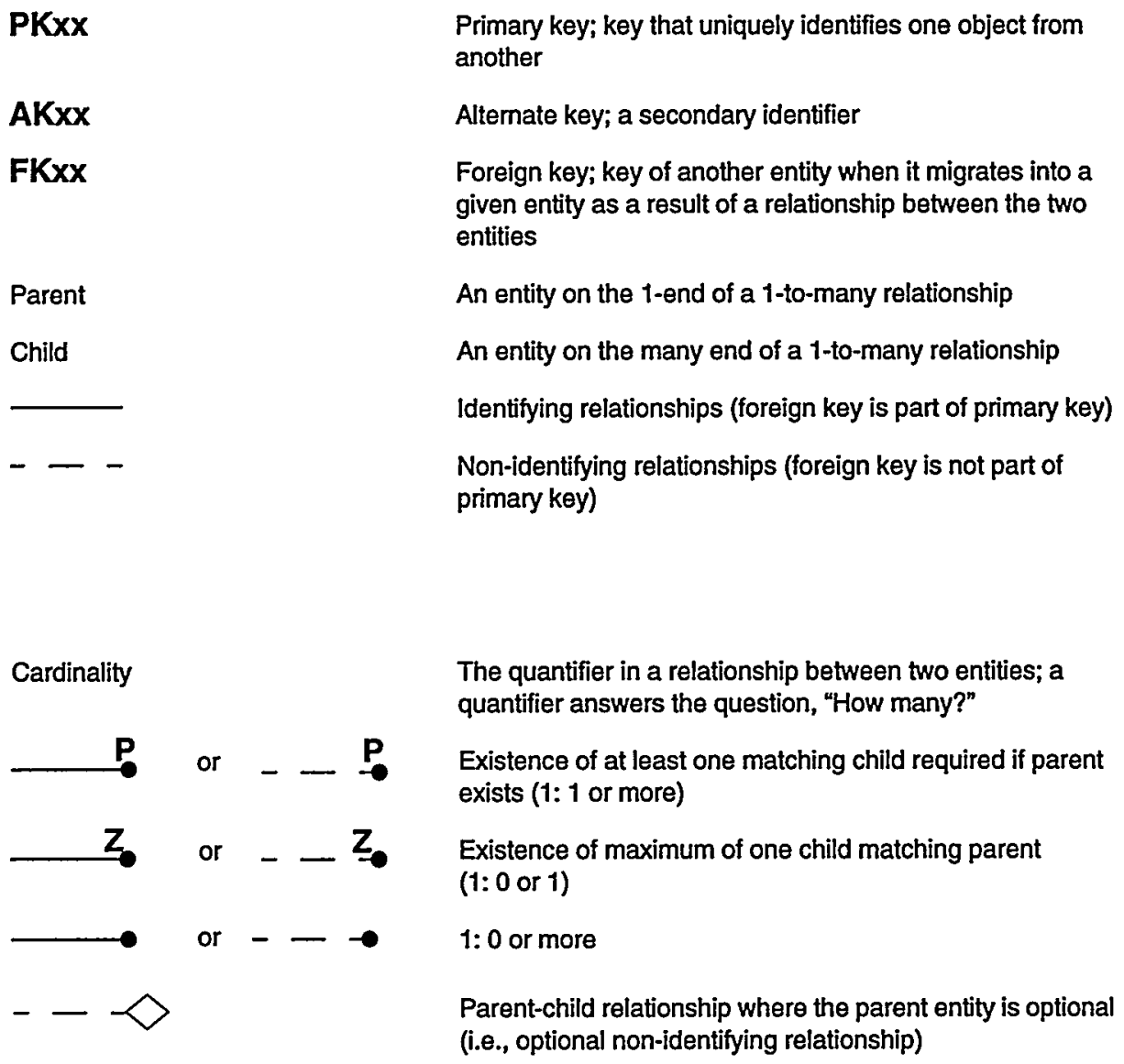


DB Schema

Figure 11 DB Schema
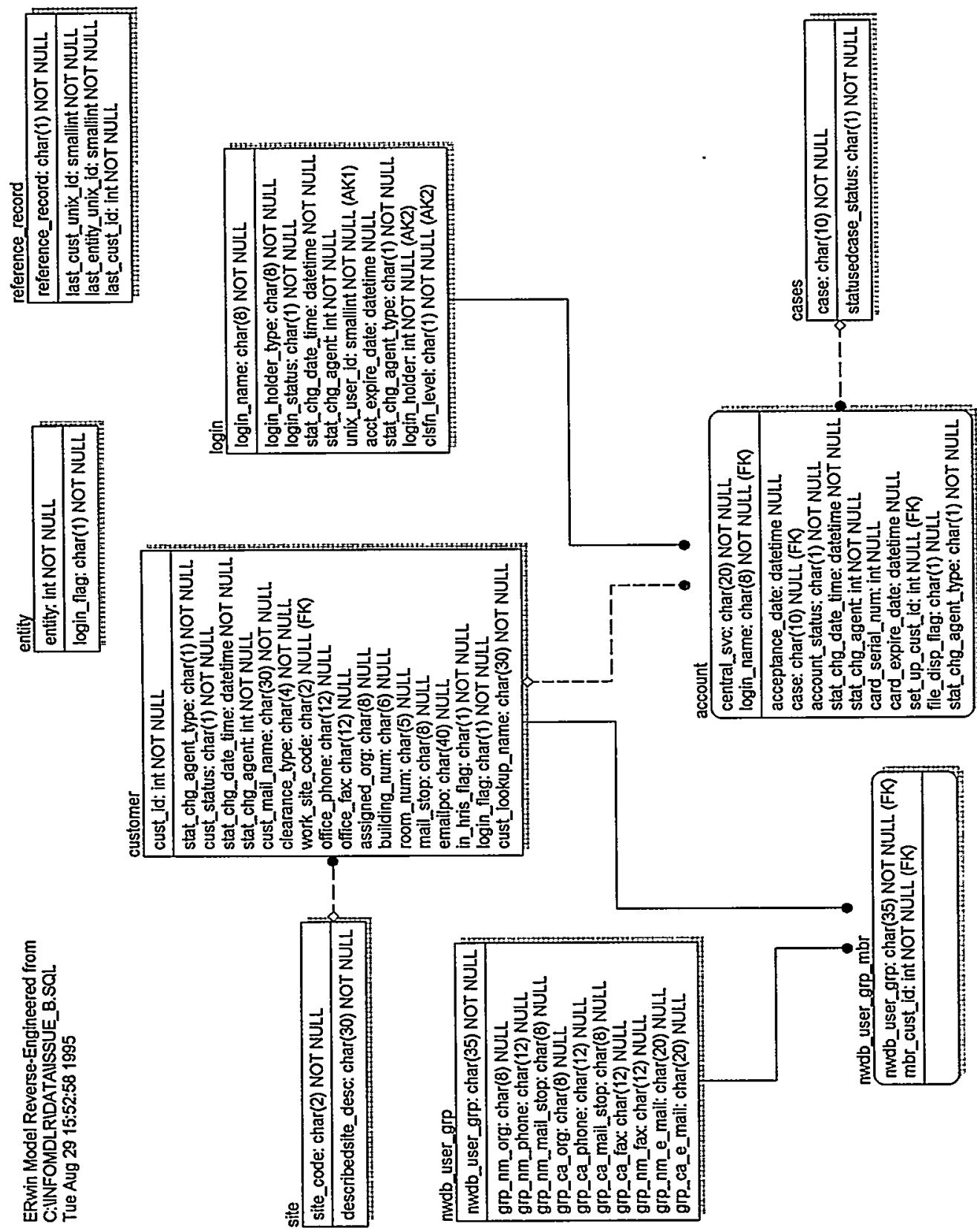


\section{Extended Dependencies and Implementation Constraints}

\section{Deliverable 10}

This deliverable consists of a formal definition of precedence required in the flow steps.

This example shows an overall description that applies to all screens. The NWDB does not have complex algorithms or calculations. If a system does contain these, they would be included in this deliverable.

The format presented here was very useful for the testers and for generating the error messages, and it helped clarify material for the user documentation. This format is not necessarily recommended for every system.

This example extracts specific information from the NWDB. To view the complete deliverable for this subset of the NWDB, see the World Wide Web:

http:// sass902d.itd.sandia.gov/SILCExam.pdf 


\title{
Extended Dependencies and Implementation Constraints
}

\author{
Process Flow Dependencies (Menu)
}

Figure 12 Network Database Menus

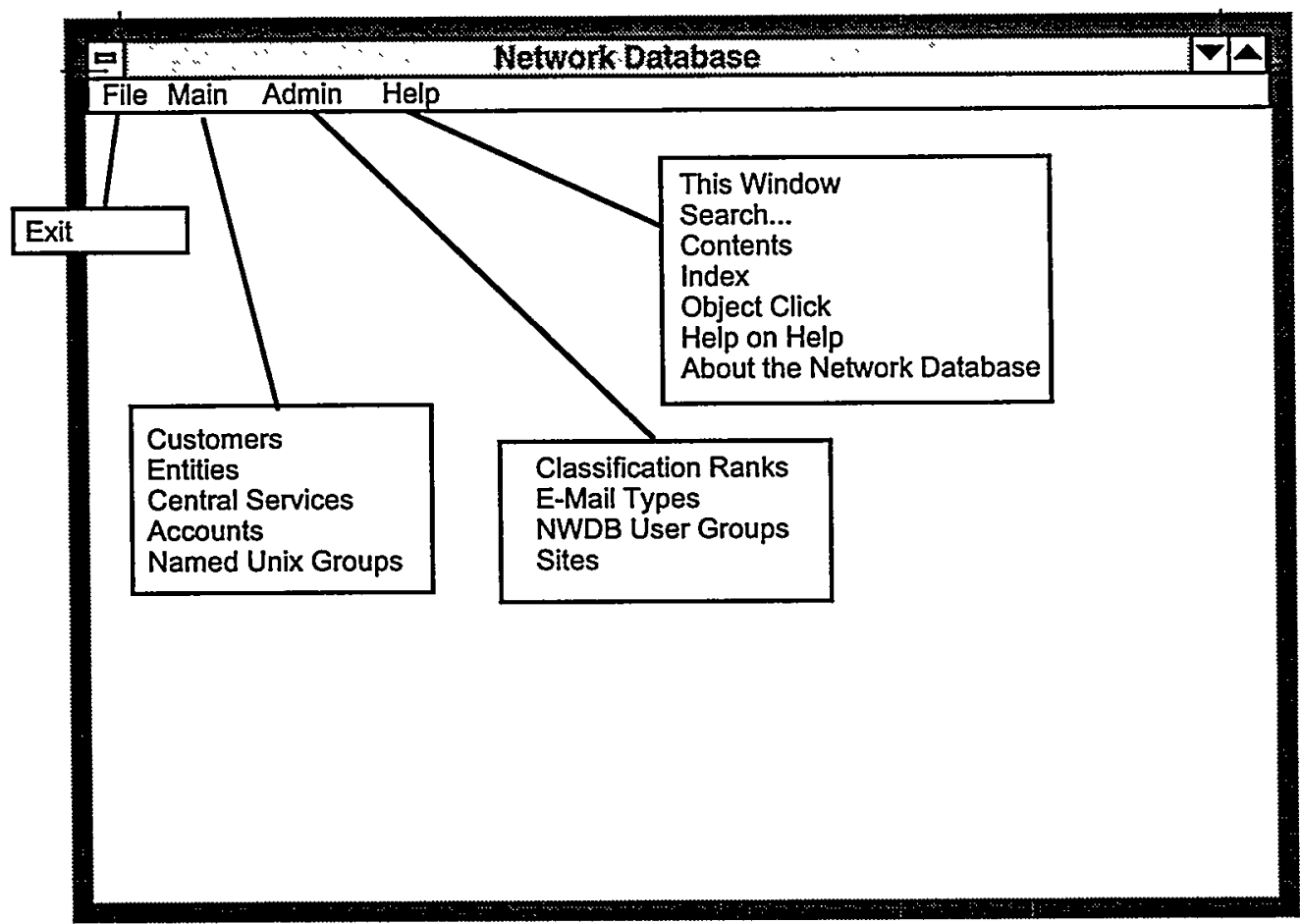

\section{General Screen Criteria (Reusable GUI Guidelines and Framework)}

gen-10 The menus should match what is shown. Each menu pick should bring up the correct screen. The screen title should match the menu.

gen-20 For every input field: If the user tries to type data into a field that does not match the basic data type as shown in the IDEF1X diagram, (e.g., alpha data into a numeric field or numeric data into an alpha field) the system should not allow it, preferably by not allowing the data to be typed into the field in the first place.

gen-30 When a field in a record is listed as "Not Null" on the IDEF1X diagram, and that record is stored from a screen, the screen should either require the user to fill in that field (if the field shows on the screen) or loaded with an appropriate default (if the field does not show on the screen). 
gen-40 Primary key fields may not be Changed once added. There is one exception, as explained in login-220, which is login names (in the case of login names we will have to go out and fix all the related foreign keys to match the new login key). Otherwise, if key fields have been changed and the user clicks Change, an error message should appear.

gen-50 If a user has entered or changed data on a Detail screen (i.e., not just search criteria on a List screen) and then tries to close the screen either by clicking the close box or by choosing Cancel, the system should pop up a warning that requires confirmation.

gen-60 An Add on any screen when an entity with that key already exists in the database should produce an error message.

gen-70 On all Deletes, the system should ask for confirmation before doing the delete.

gen-80 The Clear button should remove all data from a screen.

gen-90 Cancel (if it is not the situation where changes have been made and not saved) should simply close a screen.

gen-100 If a screen title includes the basic title plus the key of the primary entity appearing on that screen (this is true on most complex detail screens), the key shown in the title should match the key shown in the body of the screen. If the key is compound (like on the Accounts screen), its components should be separated with a “."

gen-110 When there are fields dependent on a subtype, those fields should be automatically shown when an occurrence of that subtype is on the screen, and hidden otherwise. Each such field dependency is described in the text below.

gen-120 If a user does not have privileges as a result of his NWDB user group to update data on a screen, "Add," "Change," and "Delete" buttons should be grayed out. This includes the Add buttons on the List screens.

gen-150 The domain of status fields (other than doc_status, which is a different concept), should always be "a" and "i." Status field is always in a little pick-list. It may be shown initially with blanks to force input.

The domain of status_chg_agent_type and rcd_chg_agent_type is "c" and "p" (i.e., customer and process). This does not show on screens.

gen-180 Flags should be stored as "N" or "Y," and are shown on screens as "Yes" and "No," so we want to convert them back and forth, showing "Yes" and "No" in the pick list, and storing " $\mathrm{N}$ " and "Y."

gen-190 Dates must be entered as 6 digits in the sequence MMDDYY. The system should insert slashes in between as necessary, and display the date in the format $\mathrm{MM} / \mathrm{DD} / \mathrm{YY}$. 


\section{Input Process Dependencies}

In the NWDB, most input process constraints and dependencies were described in the Extended Presentation Sets (see "Extended Presentation Sets" on page A-37).

Another input dependency is an update flag that shows that the proper cycle for the Human Resources Information System (HRIS) has been executed. This will give current information accessed directly for the status and certain attributes of line organization individuals.

\section{Output Process Dependencies}

Onscreen reports use the List, Detail, and Report screens (see "Extended Presentation Sets" on page A-37).

Batch Reports include Password Reauthorization List, generated monthly. This is computed on an 11-month warning, with a 12-month expiration for each individual account. The format of this 11 -month warning or notice normally would appear here.

Output files with e-mail address updates are generated daily and sent to HRIS. The format of this file normally would appear here.

\section{Output Processes}

In general, every table (each table should more-or-less map to a logical object) should be listable from its home input screen based on full, partial, or "list them all" input of the table's primary key, and from this list a user should be able to pick an instance to expand or update. When a given object is listed, as many additional attributes of that object (besides its key) should be shown as possible in the list to help the user reference the object. This type of output should basically be a given for all tables. Below we specify additional outputs, primarily because they either have more complex selection criteria, are output only periodically, or are electronic files to be sent to other systems.

Reports show as "basic queries" which should produce a wide range of on-demand information to serve most any need, and then as specific report definitions grouped under the NWDB user access type that would be the main users.

Where a report's output method is listed as "Standard," we mean that the report could, at the user's choice and with the click of a button, be (a) printed as hard copy at a userspecified printer with an appropriate cover banner identifying the requesting user (b) emailed to an e-mail address that they provide, or (c) downloaded to a user-specified machine under a user-specified file name. (Note: this latter capability requires a machine set-up that will be controlled by NWDB administrators outside of the NWDB system itself. Only "trusted" machines will be allowed.)

In general, if any query generates more than 100 lines of output, the system should stop and ask the user if he or she wants to continue, and then again at 200 lines of output, etc. This check should be bypassed for certain large standard reports. 


\section{IDEF0 Decomposition}

\section{Deliverable 11}

IDEF0 decomposition is a formal, hierarchical breakdown of the functions or processes that the software will provide. In addition to showing each process in progressively more detail, these graphical charts also emphasize:

- The inputs, which are transformed by the process

- The outputs that result from the process

- Inputs that are not transformed, but are controls on the process

- The "mechanisms" that are involved or use the processes

Note: Figures on the following pages include explanatory notes. 
IDEF0 Decomposition

Figure 13 Node A-0, Network Database Example

\begin{tabular}{|c|c|c|c|}
\hline $\begin{array}{l}\text { Human } \\
\text { Resources Info } \\
\text { (HRIS files) } \\
\text { Requests for } \\
\text { New/Changed } \\
\text { Services }\end{array}$ & 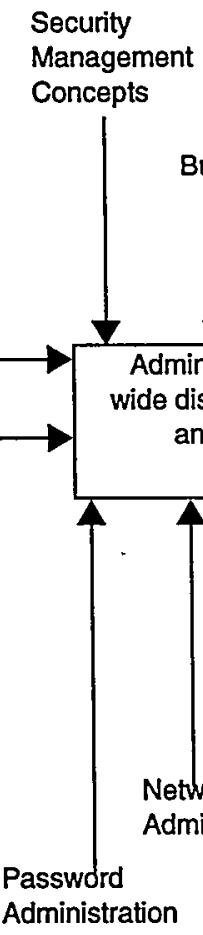 & $\begin{array}{l}\text { Sandia } \\
\text { Computer } \\
\text { Policies } \\
\text { et } \\
\text { Security } \\
\text { Administration } \\
\text { omputers } \\
\text { tration }\end{array}$ & $\begin{array}{l}\text { Security Plans } \\
\text { Network Reports } \\
\text { Database of } \\
\text { Network Information } \\
\text { New/Renewed } \\
\text { Customer } \\
\text { Accounts }\end{array}$ \\
\hline
\end{tabular}

Reading from the top, clockwise:

- The arrows entering the top of the box containing the process description show "controls" on this process.

- The arrows exiting to the left show the outputs.

- The bottom arrows show mechanisms, i.e., answers to who or what will act on this process.

- Finally the arrows entering from the right show those inputs that will be affected by the processes and transformed to an output. 
Figure 14 Node A0, Administer Enterprise-Wide Distributed Networks

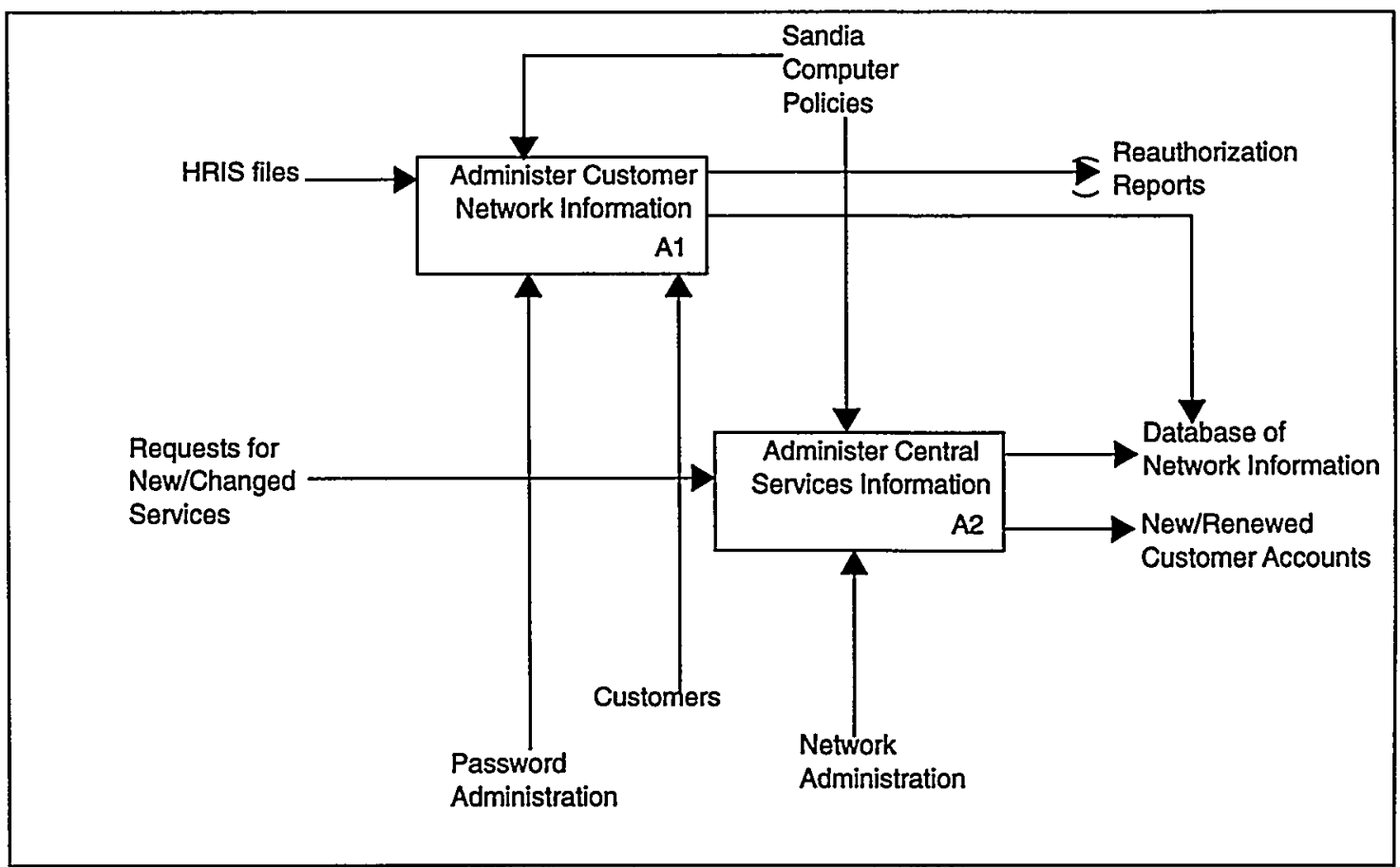

The A0 process shown here is decomposed into two subprocesses, A1 and A2. If an external entity was not noted with exact wording in the higher-level diagram, a tunnel marker displays around the arrowhead. 
Figure 15 Node A1, Administer Customer Network Information

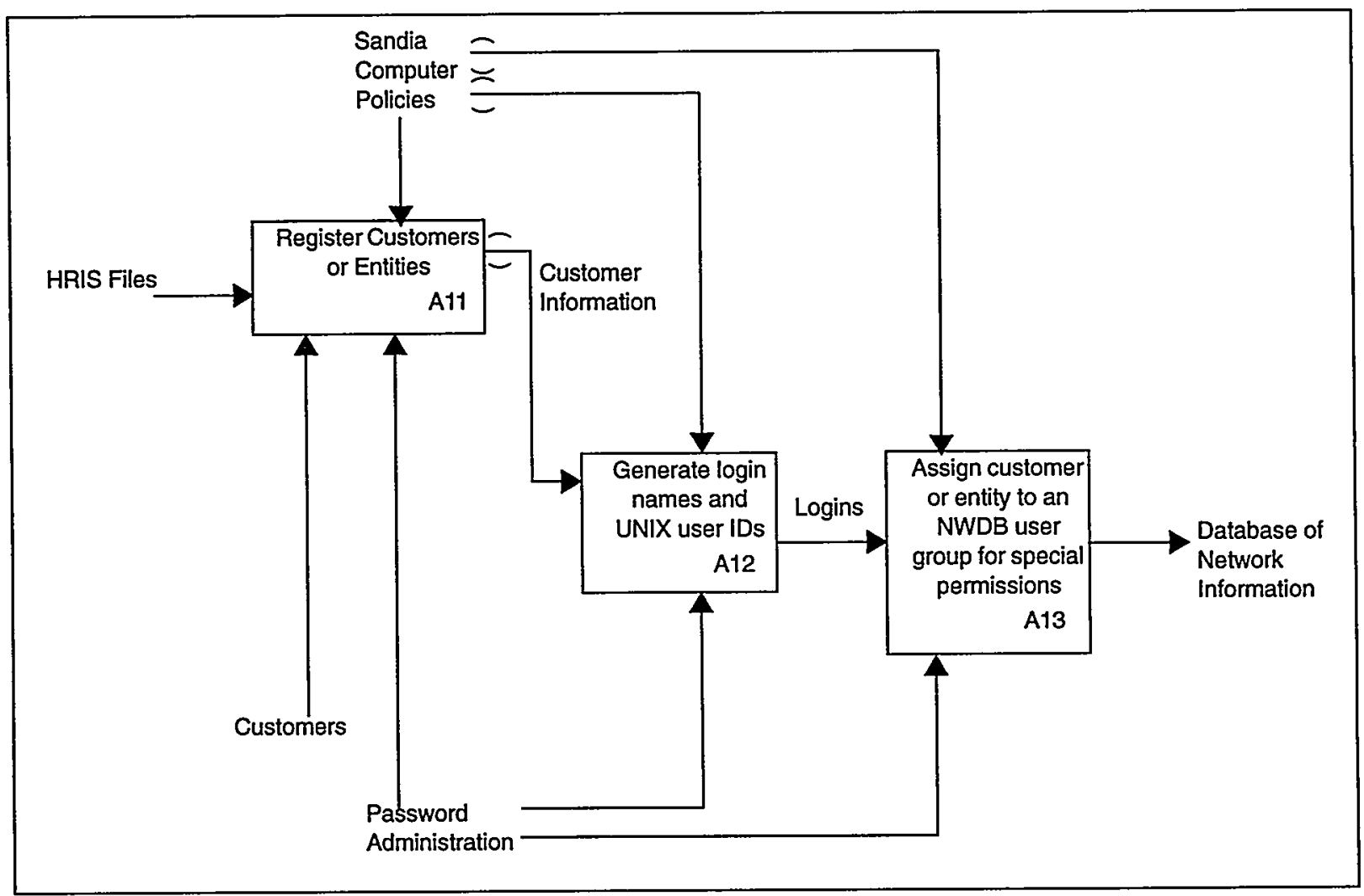

The A1 subprocess is further broken down into activities A11, A12, and A13. Each of these can be decomposed again until the granularity is such as to describe the software processes to be managed in writing and deploying the system. 


\section{Figure 16 Node A2, Administer Central Services Information}

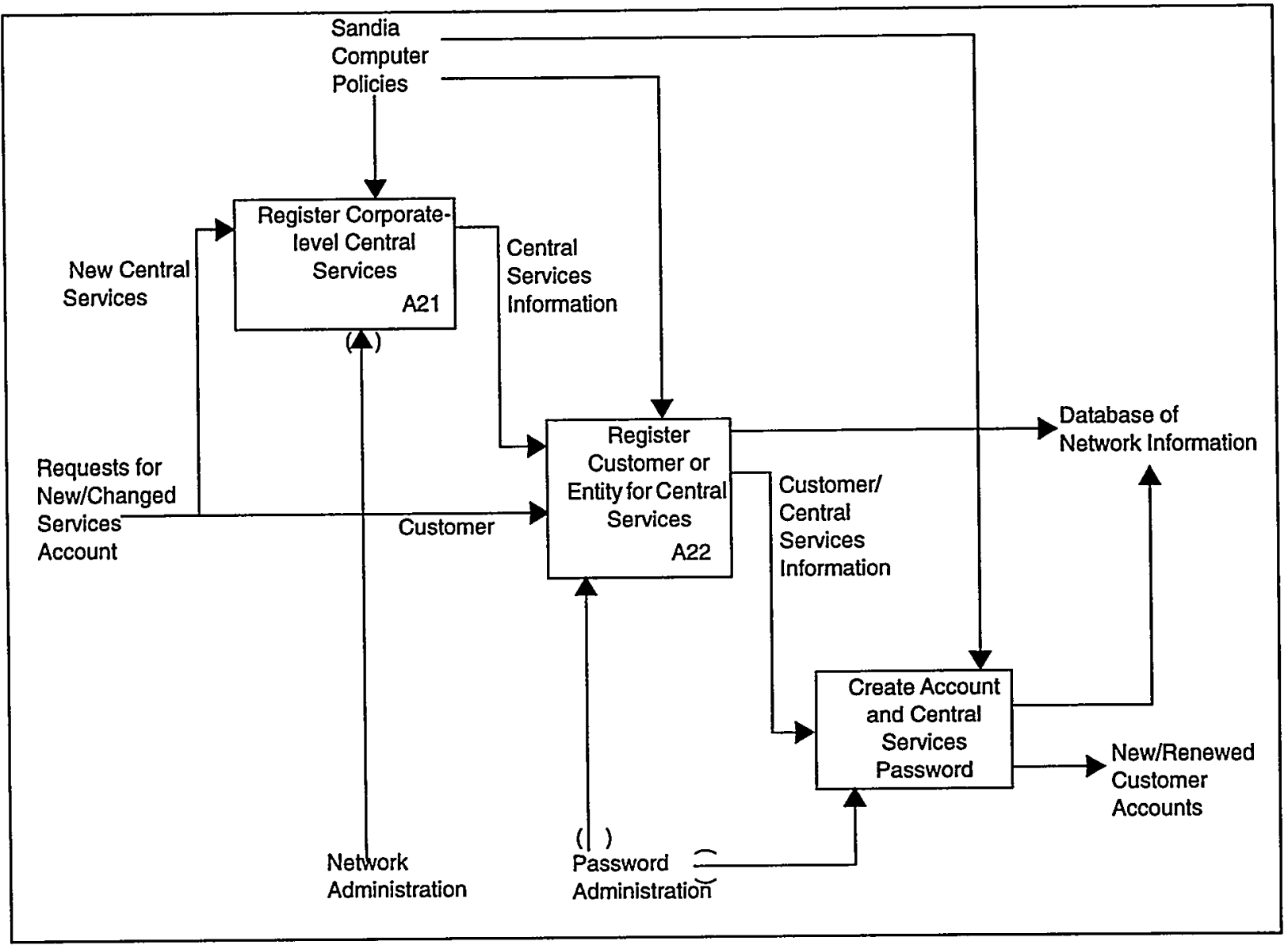

The A2 subprocess is further broken down into activities A21, A22, and A23. 


\section{Test Plan, Test Database, and Test Data}

\section{Deliverable 12}

Test data may be acquired in the modeling phase as valid and invalid examples of each fact. The design of the test plan will validate the modeling examples, in addition to other tests as needed to check the algorithms and the output or results of the processes and the system. The test database will be a significant data set to establish and carry out the test plan. It must be a reusable baseline database, and it should be established early in the prototyping process.

The detailed specifications of screen functions and constraints for each process are written for the NWDB as numbered constraints for each screen. These constraints are essentially the test plan-to verify that the developer implemented every constraint as specified.

In addition, an experienced programmer will apply the testing technique called "error guessing." Without using any specific methodology, the veteran coder can "smell out" errors. Given a particular application, this tester can intuitively guess certain probable types of errors and test to expose these errors, if they are present (Reference 18). All tests will be run on the primary software platform (PC) and the other platforms prior to production.

The tester will document the results of all tests, using the Microsoft Word template (see "Test Incident Report" on page A-59).

Format and content of each report and datafile are validated by the recipients (customers). 


\section{Test Incident Report}

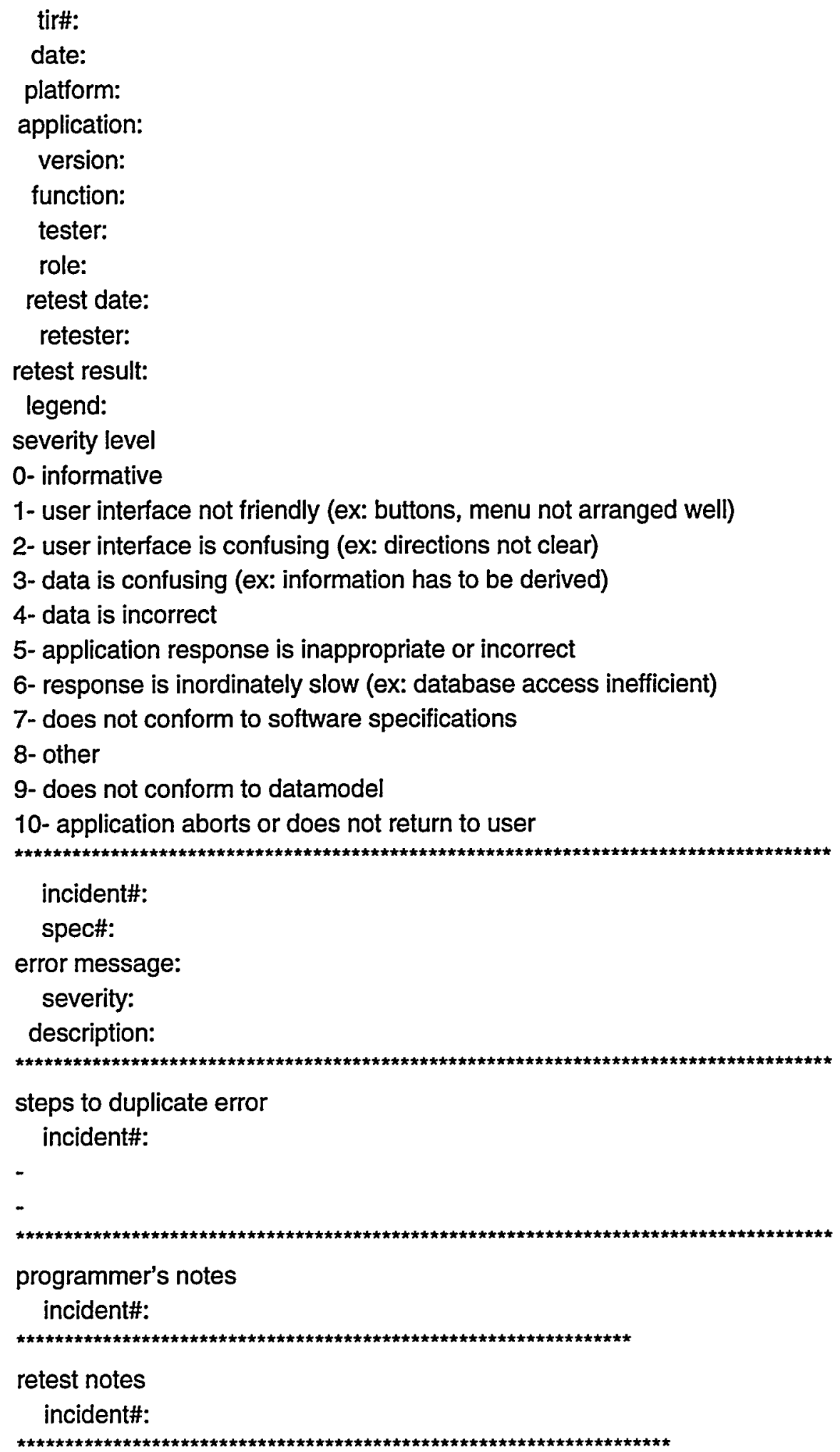




\section{Test Data/Test Database Listing}

Table 10 customer-Test Data

\begin{tabular}{|c|c|c|c|c|c|c|c|c|c|c|c|c|c|c|c|c|c|}
\hline $\begin{array}{c}\text { cust } \\
\text { id }\end{array}$ & $\begin{array}{l}\text { stat_- } \\
\text { chg_ } \\
\text { agent } \\
\text {-type }\end{array}$ & $\begin{array}{l}\text { cust } \\
\text { _stat } \\
\text { us }\end{array}$ & $\begin{array}{l}\text { stat_chg } \\
\text { _date_time }\end{array}$ & $\begin{array}{l}\text { stat } \\
\text { ch̄g } \\
\text { _ag } \\
\text { ent }\end{array}$ & $\begin{array}{l}\text { cust_- } \\
\text { mail_- } \\
\text { name }\end{array}$ & $\begin{array}{c}\text { cle } \\
\text { ara } \\
\text { nce } \\
\text { ty } \\
\text { pe }\end{array}$ & $\begin{array}{l}\text { work_ } \\
\text { site_- } \\
\text { code }\end{array}$ & $\begin{array}{l}\text { office_- } \\
\text { phone }\end{array}$ & $\begin{array}{c}\text { office } \\
\text { fax }\end{array}$ & $\begin{array}{l}\text { assign } \\
\text { ed_org }\end{array}$ & $\begin{array}{l}\text { build } \\
\text { ing_ } \\
\text { num }\end{array}$ & $\begin{array}{c}\text { room_ } \\
\text { num }\end{array}$ & mail_ & $\begin{array}{c}\text { email } \\
\text { po }\end{array}$ & $\begin{array}{l}\text { in } \\
\text { hris } \\
\text { flag }\end{array}$ & $\begin{array}{l}\log \\
\text { in } \\
\text { flag }\end{array}$ & $\begin{array}{l}\text { cust__ } \\
\text { lookup__ } \\
\text { name }\end{array}$ \\
\hline 1 & C & $a$ & $\begin{array}{l}\text { 9/15/95 } \\
\text { 12:00:00 AM }\end{array}$ & 1 & $\begin{array}{l}\text { David S } \\
\text { Cuyler }\end{array}$ & $\mathbf{Q}$ & SA & $\begin{array}{l}000- \\
0000\end{array}$ & $\begin{array}{l}000- \\
0000\end{array}$ & 00000 & 000 & 000 & 0000 & PRINT & $\bar{Y}$ & $\bar{Y}$ & $\begin{array}{l}\text { CUYLER, } \\
\text { DAVID S. }\end{array}$ \\
\hline 3 & $p$ & $a$ & $\begin{array}{l}\text { 10/15/95 } \\
12: 00: 00 \mathrm{AM}\end{array}$ & 1 & $\begin{array}{l}\text { Donna } \\
\text { B Black }\end{array}$ & $\mathbf{Q}$ & $S A$ & $\begin{array}{l}505- \\
845- \\
9987\end{array}$ & $\begin{array}{l}505- \\
844- \\
9344\end{array}$ & 04832 & 880 & D99 & 0884 & PRINT & $Y$ & $Y$ & $\begin{array}{l}\text { BLACK, } \\
\text { DONNAB. }\end{array}$ \\
\hline 4 & $p$ & $a$ & $\begin{array}{l}\text { 10/15/95 } \\
12: 00: 00 \mathrm{AM}\end{array}$ & 1 & $\begin{array}{l}\text { Mary F } \\
\text { Johnson }\end{array}$ & $\mathbf{Q}$ & SA & $\begin{array}{l}505- \\
945- \\
8898\end{array}$ & $\begin{array}{l}505- \\
844- \\
9344\end{array}$ & 04832 & 880 & D99 & 0884 & PRINT & $Y$ & $Y$ & $\begin{array}{l}\text { JOHNSON, } \\
\text { MARY F. }\end{array}$ \\
\hline
\end{tabular}

Table 11 account-Test Data

\begin{tabular}{|c|c|c|c|c|c|c|c|c|c|c|c|}
\hline $\begin{array}{c}\text { central__ } \\
\text { svc }\end{array}$ & $\underset{\text { name }}{\text { login }}$ & $\begin{array}{c}\text { acceptance } \\
\text { date }\end{array}$ & case & $\begin{array}{l}\text { account } \\
\text { status }\end{array}$ & $\begin{array}{l}\text { stat_chg } \\
\text { date_time }\end{array}$ & $\begin{array}{l}\text { stat_ } \\
\text { chg_ } \\
\text { agent }\end{array}$ & $\begin{array}{c}\text { card__ } \\
\text { serial__ } \\
\text { num }\end{array}$ & $\begin{array}{c}\text { card } \\
\text { expire } \\
\text { date }\end{array}$ & $\begin{array}{l}\text { set_- } \\
\text { up_ } \\
\text { cust } \\
\text { id }\end{array}$ & $\underset{\text { flag }}{\text { file_- }}$ & $\begin{array}{l}\text { stat_- } \\
\text { chg_ } \\
\text { agent } \\
\text { type }\end{array}$ \\
\hline LIS & dbblack & $\begin{array}{l}10 / 15 / 95 \\
12: 00: 00 \mathrm{AM}\end{array}$ & 0100589000 & $a$ & $\begin{array}{l}10 / 15 / 95 \\
12: 00: 00 \mathrm{AM}\end{array}$ & 1 & 0 & $\begin{array}{l}\text { 10/15/95 } \\
12: 00: 00 \mathrm{AM}\end{array}$ & 3 & $y$ & $p$ \\
\hline LIS & dscuyle & $\begin{array}{l}\text { 9/15/95 } \\
12: 00: 00 \mathrm{AM}\end{array}$ & 3321400000 & a & $\begin{array}{l}\text { 9/15/95 } \\
\text { 12:00:00 AM }\end{array}$ & 1 & 0 & $\begin{array}{l}\text { 9/15/95 } \\
\text { 12:00:00 AM }\end{array}$ & 1 & $Y$ & $p$ \\
\hline LIS & mfjohns & $\begin{array}{l}\text { 10/15/95 } \\
12: 00: 00 \mathrm{AM}\end{array}$ & 0100589000 & a & $\begin{array}{l}\text { 10/15/95 } \\
12: 00: 00 \mathrm{AM}\end{array}$ & 1 & 0 & $\begin{array}{l}\text { 10/15/95 } \\
12: 00: 00 \mathrm{AM}\end{array}$ & 4 & $y$ & $\mathrm{p}$ \\
\hline SYBLIS & dscuyle & $\begin{array}{l}9 / 15 / 95 \\
12: 00: 00 \mathrm{AM}\end{array}$ & 3321400000 & a & $\begin{array}{l}9 / 15 / 95 \\
12: 00: 00 \mathrm{AM}\end{array}$ & 1 & 0 & $\begin{array}{l}9 / 15 / 95 \\
12: 00: 00 \mathrm{AM}\end{array}$ & 1 & $\mathrm{Y}$ & $p$ \\
\hline Secure Gray & dduggan & $\begin{array}{l}\text { 9/15/95 } \\
12: 00: 00 \mathrm{AM}\end{array}$ & 0100589000 & a & $\begin{array}{l}\text { 9/15/95 } \\
12: 00: 00 \mathrm{AM}\end{array}$ & 1 & 0 & $\begin{array}{l}\text { 9/15/95 } \\
\text { 12:00:00 AM }\end{array}$ & 2 & $Y$ & $p$ \\
\hline
\end{tabular}


Table 12 login-Test Data

\begin{tabular}{|c|c|c|c|c|c|c|c|c|c|}
\hline$\underset{\text { name }}{\text { login }}$ & $\begin{array}{c}\text { login_- } \\
\text { holder_t } \\
\text { ype }\end{array}$ & $\begin{array}{l}\text { login } \\
\text { status }\end{array}$ & stat_chg_date_time & $\begin{array}{l}\text { stat__ } \\
\text { chg__ } \\
\text { agent }\end{array}$ & $\underset{\text { user_id }}{\text { unix }}$ & acct_expire_date & $\begin{array}{c}\text { stat__ } \\
\text { chg__ } \\
\text { agent_- } \\
\text { type }\end{array}$ & $\begin{array}{l}\text { Jogin } \\
\text { holder }\end{array}$ & $\begin{array}{l}\text { clsfn } \\
\text { level }\end{array}$ \\
\hline dbblack & customer & a & 9/12/95 12:00:00 AM & $\overline{1}$ & $\overline{411}$ & 9/12/96 12:00:00 AM & $p$ & 3 & s \\
\hline dduggan & customer & $a$ & 9/12/95 12:00:00 AM & 1 & 922 & 9/12/96 12:00:00 AM & p & 2 & $\mathbf{s}$ \\
\hline dscuyle & customer & $a$ & 9/12/95 12:00:00 AM & 1 & 1 & 9/12/95 12:00:00 AM & $p$ & 1 & $u$ \\
\hline mfjohns & customer & a & 10/12/95 12:00:00 AM & 1 & 222 & 10/12/96 12:00:00 AM & $p$ & 4 & s \\
\hline
\end{tabular}

Table 13 nwdb_user_grp_Test Data

\begin{tabular}{|c|c|c|c|c|c|c|c|c|c|c|}
\hline $\begin{array}{c}\text { nwdb_user } \\
\text { _grp }\end{array}$ & $\begin{array}{c}\text { grp_nm } \\
\text { _org }\end{array}$ & $\underset{\text { phone }}{\text { grp_nm_n }}$ & $\underset{\text { mail_stop }}{\text { grp_nm_ }}$ & $\begin{array}{c}\text { grp_ca } \\
\text { _org }\end{array}$ & $\begin{array}{c}\text { grp_ca_ } \\
\text { phone }\end{array}$ & $\underset{\text { mail_sto }}{\text { grp_ca_}}$ & $\underset{\text { fax }}{\text { grp_ca_ }}$ & $\underset{\text { fax }}{\text { grp_nm_ }}$ & $\underset{\text { e_mail }}{\text { grp_nm_ }}$ & $\underset{\text { e_mail }}{\text { grp_ca_ }}$ \\
\hline $\begin{array}{l}\text { LAN Points of } \\
\text { Contact }\end{array}$ & 13911 & $\overline{505-234-5677}$ & 1009 & 08534 & $\overline{~ 510-294-2222}$ & 9001 & $\begin{array}{l}510-294- \\
9999\end{array}$ & $\begin{array}{l}505-844- \\
3333\end{array}$ & $\begin{array}{l}\text { dduggan@ } \\
\text { sandia.gov }\end{array}$ & $\begin{array}{l}\text { mjsimth@ } \\
\text { sandia.gov }\end{array}$ \\
\hline $\begin{array}{l}\text { Password } \\
\text { Administration }\end{array}$ & 13316 & $505-234-5678$ & 0661 & 08534 & $510-294-2222$ & 9001 & $\begin{array}{l}510-294- \\
9999\end{array}$ & $\begin{array}{l}505-844- \\
3333\end{array}$ & $\begin{array}{l}\text { dduggan@ } \\
\text { sandia.gov }\end{array}$ & $\begin{array}{l}\text { mjsmith@ } \\
\text { sandia.gov }\end{array}$ \\
\hline
\end{tabular}

Table 14 nwdb_user_grp_mbr-Test Data

\begin{tabular}{|ll|}
\hline \multicolumn{1}{|c|}{ nwdb_user_grp } & mbr_cust_id \\
\hline \hline LAN Points of Contact & 3 \\
Password Administration & 1 \\
Password Administration & 2 \\
Password Administration & 4 \\
\hline
\end{tabular}

Table 15 cases-Test Data

\begin{tabular}{|cl|}
\hline case & statusedcase_status \\
\hline \hline 0000000000 & a \\
0100589000 & a \\
0101010101 & a \\
3321400000 & a \\
8999111000 & a \\
9999111000 & a \\
\hline
\end{tabular}


Table 16 site-Test Data

\begin{tabular}{|c|c|}
\hline site_code & describedsite_desc \\
\hline SA & Sandia New Mexico \\
\hline SL & Sandia California \\
\hline
\end{tabular}

Table 17 reference_record-Test Data

\begin{tabular}{|llll|}
\hline reference_record & $\begin{array}{c}\text { last_cust } \\
\text { _unix_id }\end{array}$ & $\begin{array}{c}\text { last_entity_ } \\
\text { unix_id }\end{array}$ & last_cust_id \\
\hline \hline 1 & 985 & 444 & 4 \\
\hline
\end{tabular}

Table 18 entity-Test Data

\begin{tabular}{|ll|}
\hline entity & login_flag \\
\hline 356 & $n$ \\
443 & $n$ \\
\hline
\end{tabular}




\section{Detail Process Specifications \& Algorithms}

\section{Deliverable 13}

Processes, other than elementary processes and functions that models can generate, should be documented to the level of detail that would eventually assist in the generation of code. Several formats will suffice, until an automatic code generation tool is chosen or written.

\section{NWDB Example}

This is an optional deliverable, and the NWDB example did not supply this information. It did not have extensive process algorithms, and relevant material was documented in detail as processing constraints and presentation sets (see "Extended Presentation Sets" on page A-37 and "Extended Dependencies and Implementation Constraints" on page A49). 


\section{External and Internal Interfaces}

\section{Deliverable 14}

Most systems rely on data and controls from other systems, either by direct network links or file transfer. The interfaces must be documented to the level of detail required for future maintenance of the software. If the data must be converted for this application, a conversion map will show the input and transformation of each field, and the mapping to the new software.

The Conversion Map is optional.

This example extracts specific information from the NWDB. To view the complete deliverable for this subset of the NWDB, see the World Wide Web:

http:// sass902d.itd.sandia.gov/SILCExam.pdf 


\section{External and Internal Interfaces}

The NWDB example includes these interfaces:

- Inputs from Other Systems-The Network Database receives, from Human Resources, basic data about customers who are registered in Human Resources (note that many customers are not registered in Human Resources), a list of valid contracts with begin and end dates, a list of valid buildings, a list of valid cases and case statuses, and the clearance level ("L" or "Q") of each cleared person.

- Outputs to Other Systems-The Network Database generates and sends Login Names to Human Resources to support e-mail, sends case charges for central service accounts, LAN connections, and CSU services to the Financial Information System, sends six types of files to the Domain Name servers to drive Internet traffic, and sends basic user, account, machine, and LAN connection data to the Trouble Ticket system for reference purposes.

- Other Outputs-The Network Database also generates about 30 other types of output, many of which are data files to feed various hosts and other network services.

The data must be converted for this application. The following conversion map illustrates the input and transformation of each field, and the mapping to the new software.

Table 19 Conversion Map

\begin{tabular}{|c|c|c|c|c|c|c|}
\hline \multirow[b]{2}{*}{ Facts } & \multicolumn{3}{|c|}{ Old Tables } & \multicolumn{3}{|c|}{ New Tables } \\
\hline & Table(s) & $\begin{array}{l}\text { Column } \\
\text { Name of } \\
\text { Sentence } \\
\text { Subject }\end{array}$ & $\begin{array}{l}\text { Column } \\
\text { Name of } \\
\text { Sentence } \\
\text { Object }\end{array}$ & Table(s) & $\begin{array}{l}\text { Column } \\
\text { Name of } \\
\text { Sentence } \\
\text { Subject }\end{array}$ & $\begin{array}{c}\text { Column Name } \\
\text { of Sentence } \\
\text { Object }\end{array}$ \\
\hline $\begin{array}{l}\text { A customer has a first name. } \\
\text { On HR load, derive by parsing out name. }\end{array}$ & user_info & & $\begin{array}{l}\text { fname } \\
\text { name }\end{array}$ & customer & cust_id & first_name \\
\hline $\begin{array}{l}\text { A customer has a middle name. } \\
\text { On HA load, derive by parsing out name. }\end{array}$ & $\begin{array}{l}\text { user_info } \\
\text { rpt_persor }\end{array}$ & & $\begin{array}{l}\text { mname } \\
\text { name }\end{array}$ & customer & cust_id & middle_name \\
\hline $\begin{array}{l}\text { A customer has a last name. } \\
\text { On HR load, derive by parsing out name. }\end{array}$ & $\begin{array}{l}\text { user_info } \\
\text { rpt_persol }\end{array}$ & & $\begin{array}{l}\text { Iname } \\
\text { name }\end{array}$ & customer & cust_id & last_name \\
\hline $\begin{array}{l}\text { A customer is identified by a mail name. } \\
\text { If the customer first, middle, or last name is } \\
\text { changed, do the following: The customer's } \\
\text { first name, a space, the first character of } \\
\text { the middle name and a space (if there is a } \\
\text { middle name), and last name should be } \\
\text { concatenated to form the customer mail } \\
\text { name. }\end{array}$ & $\begin{array}{l}\text { user_info } \\
\text { rpt_person }\end{array}$ & & $\begin{array}{l}\text { fname } \\
\text { mname } \\
\text { Iname } \\
\text { name }\end{array}$ & customer & cust_id & cust_mail_name \\
\hline
\end{tabular}


Table 19 Conversion Map (Continued)

\begin{tabular}{|c|c|c|c|c|c|c|}
\hline & \multicolumn{3}{|c|}{ Old Tables } & \multicolumn{3}{|c|}{ New Tables } \\
\hline Facts & Table(s) & $\begin{array}{l}\text { Column } \\
\text { Name of } \\
\text { Sentence } \\
\text { Subject }\end{array}$ & $\begin{array}{l}\text { Column } \\
\text { Name of } \\
\text { Sentence } \\
\text { Object }\end{array}$ & Table(s) & $\begin{array}{l}\text { Column } \\
\text { Name of } \\
\text { Sentence } \\
\text { Subject }\end{array}$ & $\begin{array}{c}\text { Column Name } \\
\text { of Sentence } \\
\text { Object }\end{array}$ \\
\hline $\begin{array}{l}\text { A customer is identified by a lookup name. } \\
\text { If the customer first, middie, or last name is } \\
\text { changed, do the following: The customer's } \\
\text { last name, a comma, a space, first name, } \\
\text { and if there is a middle name, another } \\
\text { space, the first character of the middle } \\
\text { name and a period should be } \\
\text { concatenated to form the customer lookup } \\
\text { name. }\end{array}$ & user_info & & $\begin{array}{l}\text { fname } \\
\text { miname } \\
\text { Iname } \\
\text { name }\end{array}$ & customer & cust_id & $\begin{array}{l}\text { cust_lookup_ } \\
\text { name }\end{array}$ \\
\hline $\begin{array}{l}\text { A customer holds a clearance. } \\
\text { Clearance code must be either " } Q,{ }^{n} \text { "L," or } \\
\text { "none." Clearance code should } \\
\text { automatically default to "none" unless } \\
\text { otherwise obtained from the security file. }\end{array}$ & clearance & & clearance_type & customer & cust_id & clearance_type \\
\hline $\begin{array}{l}\text { A customer is typed by a customer type. } \\
\text { Note: Customer type }\end{array}$ & $\begin{array}{l}\text { user_info } \\
\text { rpt_persort. }\end{array}$ & & $\begin{array}{l}\text { emp_type } \\
\text { pertype } \\
\text { nemtype }\end{array}$ & customer & cust_id & cust_type \\
\hline & user_info & & & customer & cust_id & \\
\hline $\begin{array}{l}\text { A customer works at a site, } \\
\text { NWDB values not the same as HR. Need } \\
\text { translate to HR codes. Must be upper } \\
\text { case. } \\
\text { Site is required for customers of type } \\
\text { "sandian" }\end{array}$ & $\begin{array}{l}\text { user_info } \\
\text { rpt_person }\end{array}$ & & $\begin{array}{l}\text { site } \\
\text { wrsitcd }\end{array}$ & customer & cust_id & work_site_code \\
\hline $\begin{array}{l}\text { A customer answers at a phone number. } \\
\text { Phone numbers from HR should be stored } \\
\text { without embedded dashes-just as a } \\
\text { number. }\end{array}$ & user_info & & $\begin{array}{l}\text { uphone } \\
\text { ofcphone }\end{array}$ & customer & cust_jid & office_phono \\
\hline $\begin{array}{l}\text { A customer receives FAXes at a phone } \\
\text { number. }\end{array}$ & rpt_person & & faxnum & customer & cust_id & office_fax \\
\hline $\begin{array}{l}\text { A customer works for an organization. } \\
\text { A customer must work for an organization } \\
\text { if the customer type is "sandian." } \\
\text { Org. must be a five-digit number, with a } \\
\text { leading zero as necessary. In the HR files } \\
\text { org. has often not been zero-filled to the } \\
\text { left. All org. numbers should be zero-filled } \\
\text { to } 5 \text { places, e.g., "1" should become } \\
\text { "00001," "1956" should become "01956." } \\
\text { Also remove any section numbers, i.e., } \\
\text { dashes and any numbers following the } \\
\text { dashes. }\end{array}$ & $\begin{array}{l}\text { user_inio } \\
\text { rpt_person }\end{array}$ & & luorg & customer & cust_id & assigned_org \\
\hline $\begin{array}{l}\text { A customer works in a bulding. } \\
\text { Strip any leading " } \mathrm{B}^{n} \text { and any embedded } \\
\text { spaces, blanks, "-" or "\%" }\end{array}$ & $\begin{array}{l}\text { user_info } \\
\text { rpt_person }\end{array}$ & & $\begin{array}{l}\text { bld } \\
\text { ofcbidg }\end{array}$ & customer & cust_id & building_num \\
\hline
\end{tabular}


Table 19 Conversion Map (Continued)

\begin{tabular}{|c|c|c|c|c|c|c|}
\hline & \multicolumn{3}{|c|}{ Old Tables } & \multicolumn{3}{|c|}{ New Tables } \\
\hline Facts & Table(s) & $\begin{array}{l}\text { Column } \\
\text { Name of } \\
\text { Sentence } \\
\text { Subject }\end{array}$ & $\begin{array}{l}\text { Column } \\
\text { Name of } \\
\text { Sentence } \\
\text { Object }\end{array}$ & Table(s) & $\begin{array}{l}\text { Column } \\
\text { Name of } \\
\text { Sentence } \\
\text { Subject }\end{array}$ & $\begin{array}{c}\text { Column Name } \\
\text { of Sentence } \\
\text { Object }\end{array}$ \\
\hline $\begin{array}{l}\text { A customer works in a room. } \\
\text { Strip any embedded spaces, blanks, } \\
4=" \text { or } 4 .\end{array}$ & $\begin{array}{l}\text { user_info } \\
\text { rpt_person }\end{array}$ & & $\begin{array}{l}\text { room } \\
\text { ofcroom }\end{array}$ & customer & cust_id & room_num \\
\hline $\begin{array}{l}\text { A customer receives internal hard-copy } \\
\text { mail at a hard-copy mail stop. } \\
\text { Mail stop is required for customers of type } \\
\text { "sandian." } \\
\text { NWDB has } 5 \text { characters - need chop off } 1 \text {. }\end{array}$ & $\begin{array}{l}\text { user_info } \\
\text { rpt_person }\end{array}$ & & $\begin{array}{l}\text { mailstop } \\
\text { mailstop }\end{array}$ & customer & cust_id & mail_stop \\
\hline $\begin{array}{l}\text { A customer receives electronic mail at an } \\
\text { E-mail post office. } \\
\text { Don't load this from old NWDB files; this } \\
\text { only comes in from HR anyway. Just load it } \\
\text { anew on the first HR load to the new } \\
\text { system. }\end{array}$ & rpt_person & & emailpo & customer & cust_id & emailpo \\
\hline 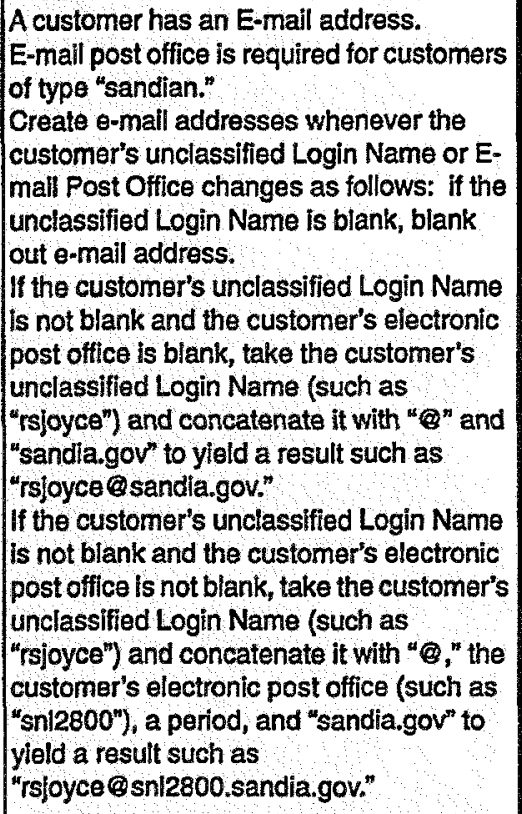 & & & & customer & cust_id & email_addr \\
\hline $\begin{array}{l}\text { A customer may be registered in the HR } \\
\text { system. } \\
\text { This flag should be set to " } Y^{m} \text { if and only if } \\
\text { the customer appears in an HR file. This } \\
\text { flag will automatically be set to "N" anytime } \\
\text { a customer is added directly on-line, and } \\
\text { then automatically set to "Y" only when and } \\
\text { if they appear in an HR file. }\end{array}$ & $\begin{array}{l}\text { - keep in } \\
\text { future }\end{array}$ & $\begin{array}{l}\text { derive on HR } \\
\text { load }\end{array}$ & & customer & cust_id & in_hris_flag \\
\hline $\begin{array}{l}\text { A customer is marked with a status. } \\
\text { Note: Customer status }\end{array}$ & $\begin{array}{l}\text { user_info } \\
\text { pt_person }\end{array}$ & & $\begin{array}{l}\text { status } \\
\text { perstat }\end{array}$ & customer & cust_id & cust_status \\
\hline $\begin{array}{l}\text { A customer had their status last changed } \\
\text { on a date. }\end{array}$ & user_info & u. & datetrans & customer & cust_id & $\begin{array}{l}\text { stat_chg_date_ } \\
\text { time }\end{array}$ \\
\hline
\end{tabular}


Table 19 Conversion Map (Continued)

\begin{tabular}{|c|c|c|c|c|c|c|}
\hline & \multicolumn{3}{|c|}{ old Tables } & \multicolumn{3}{|c|}{ New Tables } \\
\hline Facts & Table(s) & $\begin{array}{l}\text { Column } \\
\text { Name of } \\
\text { Sentence } \\
\text { Subject }\end{array}$ & $\begin{array}{l}\text { Column } \\
\text { Name of } \\
\text { Sentence } \\
\text { Object }\end{array}$ & Table(s) & $\begin{array}{l}\text { Column } \\
\text { Name of } \\
\text { Sentence } \\
\text { Subject }\end{array}$ & $\begin{array}{c}\text { Column Name } \\
\text { of Sentence } \\
\text { Object }\end{array}$ \\
\hline $\begin{array}{l}\text { A customer had their status last changed } \\
\text { at a time. }\end{array}$ & $\begin{array}{l}\text { - keep in } \\
\text { future }\end{array}$ & & & customer & cust_id & $\begin{array}{l}\text { stat_chg_date_ } \\
\text { time }\end{array}$ \\
\hline $\begin{array}{l}\text { A customer had their status last changed } \\
\text { by an agent. } \\
\text { whotrans is a Login Name. Some may be } \\
\text { missing. Convert to customer ID for new } \\
\text { system }\end{array}$ & user_info & & whotrans & customer & cust_id & stat_chg_agent \\
\hline none: & user_info & acct_status & & customer & & \\
\hline A customer is a subtype of login holder. & $\begin{array}{l}\text { - by } \\
\text { definition }\end{array}$ & & & login & & \\
\hline $\begin{array}{l}\text { An NWDB user group may be contacted in } \\
\text { California through a hard-copy mail stop. }\end{array}$ & $\begin{array}{l}\text { hand } \\
\text { enter }\end{array}$ & & & nwdb_user_grp & $\begin{array}{l}\text { nwdb_user_ } \\
\text { grp }\end{array}$ & grp_ca_mail_stop \\
\hline $\begin{array}{l}\text { A customer belongs to an NWDB user } \\
\text { group. } \\
\text { (load LAN POCs only) }\end{array}$ & $\begin{array}{l}\text { - hand } \\
\text { enter }\end{array}$ & & & nwdb_user_grp & $\begin{array}{l}\text { nwdb_user_. } \\
\text { grp }\end{array}$ & nwdb_user_grp \\
\hline
\end{tabular}




\section{List of Reused Functions}

\section{Deliverable 15}

Sharable routines such as functions and methods will be documented. Those existing functions found in the repository will be listed, along with new sharable routines that are additions to the repository.

\section{NWDB Example}

\section{Reused Object Types and Fact Types}

1. HRIS information as shown in the conversion map (see "External and Internal Interfaces" on page A-64). In summary, the following HRIS tables are reused: case, building, clearance, contract, and basic person data.

\section{Reused Functions}

1. XVT/C function libraries 


\section{User Documentation}

\section{Deliverable 16}

The purpose of user documentation is to present information in a concise, helpful, and organized manner that is necessary for accomplishing tasks. This resource includes information pertaining only to the software tool. Other documentation, such as policies, procedures, and tutorials, is outside the scope of the software project. The user documentation set includes:

- System Overview

- Purpose

- Scope

- Intended audience

- Glossary of Terms

- Field definitions with examples

- Task Procedures

- Steps required to accomplish a task or solve a problem

- Quick Reference

- Mechanics of operating the system, such as navigating, editing, entering special characters, searching, keyboard shortcuts

- Structure of the user interface, such as flow or order of screens, general explanation of screen design such as menu bar symbols

- FAQ (Frequently Asked Questions)

- Simple troubleshooting procedures

- Pitfalls to avoid

- Who to call for help

- Documented bugs

- Enhancements for future versions

Information pertaining to field domains, such as field length and type of characters allowed, should be embedded in the screen design. 


\section{Documentation Process}

\section{Deliverable 16}

The following steps are provided in lieu of an extensive NWDB example.

1. Decide which documentation tool(s) will be used, based on the chosen platform(s) and database. The selected tool(s) will determine the documentation style. If necessary, a tool should be selected that will accommodate multiple platforms so only one version of the documentation is managed. The software developer shall inform the writer of any special considerations for interfacing the completed documentation with the source code for on-line help.

2. Match the documentation set to the level of user audience, as defined in the Problem Statement (Deliverable 1).

3. Decide which format(s) will be used to present the information. The on-line help format will always be employed. Other formats, such as hard copy documentation or HTML on the World Wide Web, may be required. If other formats are required, they should be automatically produced from the original documentation, so only one version is managed.

4. Create the System Overview, based on the Problem Statement (Deliverable 1).

5. Automatically extract object definitions and examples from the Conceptual Information Model (Deliverable 3) to create the Glossary of Terms. Considering the level of user audience, it may not be necessary to define all of the objects.

6. Automatically extract procedural information from the PAST Matrix (Deliverable 6) to create the Task Procedures. This should be combined with information presented in the Extended Presentation Sets (Deliverable 8) and the Extended Dependences \& Implementation Constraints (Deliverable 10) to completely define the steps for each task.

7. Create the Quick Reference, which will include mechanics of the operating the system and the structure of the user interface. Some of this information will be found in the Extended Presentation Sets (Deliverable 8) and the Extended Dependencies \& Implementation Constraints (Deliverable 10). Other information will be obtained from the software developer. The standard GUI template or guideline may also have a Quick Reference or provide information for the application reference.

8. Create the FAQ (Frequently Asked Questions) from various sources, such as the software developers, system testers, help desk, and users of the system. This document should be updated frequently. The system should be designed so that the Corporate Computer Help Desk can respond to the user questions first and refer calls to application maintenance personnel second. Access to system change request procedures and browsing to check for request status is one way to provide information on bugs and future enhancement information.

Future State Goal: Design user interface so that no additional user documentation is required. 


\section{Test Results}

\section{Deliverable 17}

Following the test plan, a tester documents results in a standard template. If present, this would include the results from testing complex functions and algorithms.

The tests were performed as specified in the test plan and documented in the standard Test Incident Report template. These tests concentrated on the screen/data aspects of the system. Functions and algorithms are not present in a complex form in this system, so computerized testware design was not used. This would be required in other types of software. 


\title{
Test Incident Report
}

\author{
tir\#: 1000 \\ date: 06/27/95 \\ platform: $p c$ \\ application: nwdb.exe \\ version: \\ function: NWDB User Groups \\ tester: fay \\ role: nwdbdev \\ retest date: \\ retester: \\ retest result: \\ legend: \\ severity level \\ 0 - informative \\ 1- user interface not friendly (ex: buttons, menu not arranged well) \\ 2- user interface is confusing (ex: directions not clear) \\ 3- data is confusing (ex: information has to be derived) \\ 4- data is incorrect \\ 5- application response is inappropriate or incorrect \\ 6- response is inordinately slow (ex: database access inefficient) \\ 7- does not conform to software specifications \\ 8- other \\ 9- does not conform to datamodel \\ 10- application aborts or does not return to user
}

incident\#: 1

spec\#: none

error message:

severity: 0 - informative

description: I was able to invoke two copies of this screen, and query "User Group" $==$ 'Test Group' on both screens. I then changed the "mail stop" on one screen . The second screen was not refreshed with the new information. This may not be in error but may confuse the user. (should the user not be allowed to query the same entity on two different screens?)

incident\#: 2

spec\#: gen-70

error message:

severity: 7 - does not conform to software specifications

description: The system did not request a confirmation for a delete (see steps to duplicate error below) 
incident\#: 3

spec\#: none

error message: 'wugrps_pbdelete' dependent foreign key constraint...constraint name = 'central sv952442517'...command has been aborted...sql server error...failed deleting nwdb_usedr_grp

severity: 1- user interface not friendly

description: the above error messages appeared when I attempted to delete a user group.

(see steps to duplicate error below)

incident\#: 4

spec\#: usergrp-30

error message:

severity: 7 - does not conform to software specifications

description: mail stop is required to be 4 digits upon entry. I entered 2 digits and the system left filled with zeroes instead of displaying an error message

(see steps to duplicate error below)

incident\#: 5

spec\#: usergrp-40

error message:

severity: 7 - does not conform to software specifications

description:: Since telephone numbers allow '-' and '(' and ')' I was able to input a value that only consists of '-' and '(' and ')' . ex: (----)--

(see steps to duplicate error below)

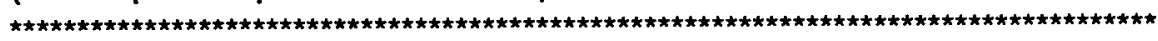

steps to duplicate error

incident\#: 2

- add a test row

- query the row to confirm that it was added

- delete the row

- notice that there is no confirmation message

- query to confirm that the row was in fact deleted

incident\#: 3

- query NWDB User group == 'Test Group'

- select delete

-notice the succession of error messages

incident\#: 4

- add or change the "mail stop" as a two digit value

- click on "add" or "change"

-notice that the value is left padded with zeroes 
incident\#: 5

." add" or "change" a test "user group"

- enter "voice","fax" values as '(-----)--'

- click on "add" or "change"

- notice the successful update

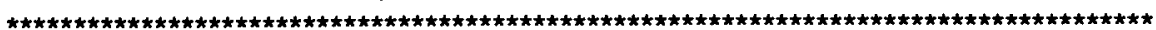

programmer's notes

incident\#:

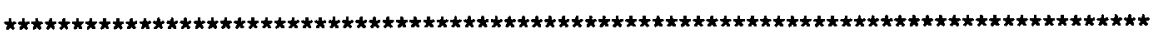

retest notes

incident\#:

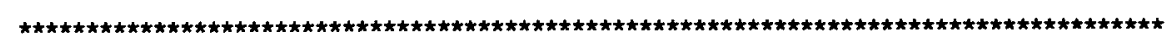





\section{Appendix B}

\section{Software Products Used for NWDB Example}

To produce the deliverables shown in Appendix A, the SILC team used a variety of software products. Table 20 lists products by deliverable. We used the word processors Microsoft Word and FrameMaker interchangeably.

Note: The "Generated" column shows deliverables that can be generated from the business rules (Deliverable 2).

Table 20 Software Products Used for NWDB Example

\begin{tabular}{|c|c|c|}
\hline Deliverable & Generated & Tools \\
\hline $\begin{array}{l}1 \\
\text { Problem statement }\end{array}$ & & $\begin{array}{l}\text { Microsoft Word } \\
\text { Design/IDEF }\end{array}$ \\
\hline $\begin{array}{l}2 \\
\text { Business rules }\end{array}$ & & $\begin{array}{l}\text { InfoModeler } \\
\text { Corporate Repository and DBArtisan }\end{array}$ \\
\hline $\begin{array}{l}3 \\
\text { Conceptual information model }\end{array}$ & $\checkmark$ & InfoModeler and filter \\
\hline $\begin{array}{l}4 \\
\text { Logical information model }\end{array}$ & $\checkmark$ & InfoModeler and ERWIN/ERX \\
\hline $\begin{array}{l}\mathbf{5} \\
\text { Elementary processes }\end{array}$ & $\checkmark$ & InfoModeler and DBArtisan \\
\hline $\begin{array}{l}6 \\
\text { Presentation sets }\end{array}$ & & MacDraw Pro and Microsoft Word \\
\hline $\begin{array}{l}7 \\
\text { CRUD matrix }\end{array}$ & $\checkmark$ & Corporate Repository; Microsoft Excel \\
\hline $\begin{array}{l}8 \\
\text { Extended presentation sets }\end{array}$ & & MacDraw Pro and Microsoft Word \\
\hline $\begin{array}{l}9 \\
\text { DB schema }\end{array}$ & $\checkmark$ & InfoModeler and ERWIN/ERX \\
\hline $\begin{array}{l}10 \\
\text { Extended dependencies and } \\
\text { implementation constraints }\end{array}$ & & MacDraw Pro and Microsoft Word \\
\hline $\begin{array}{l}11 \\
\text { IDEFO decomposition }\end{array}$ & & Design/IDEF \\
\hline $\begin{array}{l}12 \\
\text { Test data, test plan, and test } \\
\text { database }\end{array}$ & $\checkmark$ & GQL or DBArtisan \\
\hline
\end{tabular}


Table 20 Software Products Used for NWDB Example (Continued)

\begin{tabular}{|l|l|l|}
\hline \multicolumn{2}{|c|}{ Deliverable } & nenerated \\
\hline $\begin{array}{l}13 \\
\text { Detail process specifications } \\
\text { and algorithms (may include } \\
\text { design decisions) }\end{array}$ & Tools \\
\hline $\begin{array}{l}14 \\
\text { External and internal } \\
\text { interfaces (may include } \\
\text { conversion map) }\end{array}$ & & Microsoft Word \\
\hline $\begin{array}{l}15 \\
\text { List of reused functions }\end{array}$ & & Microsoft Word and Corporate Repository \\
\hline $\begin{array}{l}16 \\
\text { User documentation }\end{array}$ & & $\begin{array}{l}\text { Microsoft Word } \\
\text { Doc-to-Help }\end{array}$ \\
\hline $\begin{array}{l}17 \\
\text { Test results }\end{array}$ & Microsoft Word \\
\hline
\end{tabular}




\section{Distribution:}

$\begin{array}{ll}\text { MS 0100 } & \text { Document Processing, 7613-2 } \\ & \text { For DOE/OSTI (2) } \\ \text { MS 0619 } & \text { Print Media, 12615 } \\ \text { MS 0622 } & \text { Hank Witek, 4606 } \\ \text { MS 0622 } & \text { L. Herb Pitts, 4400 } \\ \text { MS 0629 } & \text { Paul D. Merillat, 4800 } \\ \text { MS 0629 } & \text { Al Alvarado, 4800 } \\ \text { MS 0629 } & \text { Carol Jones, 4800 } \\ \text { MS 0630 } & \text { Michael J. Eaton, 4010 } \\ \text { MS 0638 } & \text { Dwayne Knirk, 12326 } \\ \text { MS 0661 } & \text { David K. Cuyler, 4923 } \\ \text { MS 0661 } & \text { Donna S. Eaton,4816 (40) } \\ \text { MS 0661 } & \text { Elisa Kephart, 4816 } \\ \text { MS 0661 } & \text { Gary Rivord, 4816 } \\ \text { MS 0661 } & \text { Irene Thurston, 4816 } \\ \text { MS 0661 } & \text { Joe Schofield, 4816 } \\ \text { MS 0661 } & \text { John Hatley, 4816 } \\ \text { MS 0661 } & \text { Michael H. Pendley, 4612 } \\ \text { MS 0661 } & \text { Shelley Eaton, 4816 } \\ \text { MS 0661 } & \text { Charlene Strickland, 4816 } \\ \text { MS 0801 } & \text { Melissa J. Murphey, 4900 } \\ \text { MS 0803 } & \text { John F.Jones, 4600 } \\ \text { MS 0803 } & \text { John K. Sharp, 4600 } \\ \text { MS 0805 } & \text { Dorothy S. Rarick, 4911 } \\ \text { MS 0805 } & \text { Nancy Marsh, 4911 } \\ \text { MS 0806 } & \text { Michael O. Vahle, 4616 } \\ \text { MS 0806 } & \text { Leonard Stans, 4616 } \\ \text { MS 0807 } & \text { R. Michael Cahoon, 4918 } \\ \text { MS 0809 } & \text { Melville E. Mefford, 4913 } \\ \text { MS 0811 } & \text { C. Douglas Brown, 4621 } \\ \text { MS 0811 } & \text { Lucien Don Daigle, 4815 } \\ \text { MS 0812 } & \text { Bill Mertens, 4923 } \\ \text { MS 0812 } & \text { Ronald Hall, 4923 } \\ \text { MS 0813 } & \text { Jim Hamilton, 4412 } \\ \text { MS 0813 } & \text { T.C. Adams, 4913 } \\ \text { MS 0898 } & \text { R. Dennis Rowley, 4605 } \\ \text { MS 0899 } & \text { Technical Library,4414 (5) } \\ \text { MS 1090 } & \text { Grant C. Claycomb, 4814 } \\ \text { MS 1090 } & \text { Joseph A. Ruggles, 4812 } \\ \text { MS 1090 } & \text { Mary Lynn Clark, 4815 } \\ \text { MS 1090 } 1090 & \text { Scott Joyce, 4816 } \\ \text { William D. Swartz, 4411 } & \text { Andrea Cassidy, 4403 } \\ \text { Jim Stromberg, 4815 } & \text { Thomas L. Ferguson, 4813 } \\ \text { Central Technical Files, 8523-2 }\end{array}$




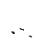




\begin{tabular}{l|l|l|l|l|l|l|l|l} 
Org. & \multicolumn{1}{l}{ Bldg. } & Name & & & & & & \\
\\
\end{tabular}

